\title{
Relaxing Credit Constraints in Emerging Economies: The impact of public loans on the productivity of Brazilian manufacturers
}

\author{
Filipe Lage de Sousa* \\ Brazilian Development Bank and Universidade Federal Fluminense \\ Gianmarco I. P. Ottaviano** \\ London School of Economics, University Bocconi Milan, CEP and CEPR
}

October 2017

\begin{abstract}
In emerging economies credit constraints are often perceived as one of the most important market frictions hampering firm productivity growth in manufacturing. Huge amount of public money is devoted to the removal of such constraints but its effectiveness is still subject to an intense policy debate. This paper contributes to this debate by analyzing the effects of the Brazilian Development Bank (BNDES) loans. Exploiting the unique features of a dataset on BNDES loans to Brazilian manufactures, it finds that credit constraints facing Brazilian manufacturing firms are real, in particular for firms that apply to BNDES repeatedly, and BNDES support has allowed granted firms to match the performance of similar unconstrained firms but not to outperform them.
\end{abstract}

Keywords: credit constraints, firm productivity, public loans, BNDES.

JEL classification: G28, O38, H25.

\footnotetext{
* Departamento de Economia, Universidade Federal Fluminense, Campus do Gragoatá, Bloco F, São Domingos, Niterói, RJ, CEP: 24210-510, Brazil.Email: fl_sousa@id.uff.br.

** Department of Economics, London School of Economics, Houghton Street, London WC2A 2AE, UK. Email: g.i.ottaviano@1se.ac.uk.
} 


\section{Highlights}

i. BNDES provides loans aimed at enhancing the productivity of manufactures.

ii. Beneficiaries are credit constrained, in particular if they apply repeatedly.

iii. Beneficiaries perform as similar unconstrained firms at least in the short run.

iv. Beneficiaries do not outperform similar unconstrained firms. 


\section{Acknowledgements}

We thank the Applied Economic Research Institute in Brazil (Instituto de Pesquisa Economica Aplicada - IPEA), Brazilian Statistical Institute (Instituto Brasileiro de Geografia e Estatistica - IBGE) and Brazilian Development Bank (Banco Nacional de Desenvolvimento Economico e Social - BNDES) for providing the data for this study. We are grateful for all comments and suggestions received from colleagues, reviewers and participants to conferences and seminars where earlier versions of this paper were presented, including ANPEC, BNDES, EIB, EBRD, IBRE/FGV, IDEAS, IPEA, LACEA, LSE, SBE and UFF. 


\section{Introduction}

Large emerging economies, such as Brazil, China and India, are considered the "markets of the future" as promising destinations for sales as well as worrying origins of new tough competitors. At the same time, manufacturers from those countries feel they are not able to compete on a level playing field with manufacturers from more advanced economies due to all sorts of market failures. In particular, credit constraints are often perceived as one of the most important market frictions constraining innovation, growth and performance as they hamper the entrepreneurial efforts of local firms. While huge amounts of public money are being devoted to the removal of such constraints, their effectiveness is still subject to an intense policy debate. Banerjee and Duflo (2014) is an example of the related recent literature.

The aim of this paper is to contribute to this debate by investigating the case of Brazil. The Brazilian government provides long-term loans through the Banco Nacional de Desenvolvimento Econômico e Social (henceforth, BNDES), a development bank whose main statutory goal is to improve Brazilian economic competitiveness without neglecting broader social and environmental aspects. ${ }^{1}$ BNDES invests in several areas including research and development, infrastructure, export support, regional and urban development. More specifically, in the case of manufacturing, BNDES finances longterm projects aimed at the creation of new plants, the enlargement of existing ones, the restructuring and the modernization of production processes, innovation and technological development. Projects are supported through loans at subsidized interest rates. All firms located in Brazil are eligible, including foreign owned ones. Moreover, banks in the private sector tap BNDES resources to provide loans for their clients' longterm projects. As a result, long-term loans in the Brazilian economy are mainly offered

\footnotetext{
${ }^{1}$ Carvalho (2014) provides a short historical description of BNDES.
} 
by BNDES funds, either by BNDES itself or by other banks using BNDES resources. ${ }^{2}$ Unsurprisingly, the importance of BNDES in the Brazilian economy is, therefore, quite sizeable: in 2012 its disbursements reached the value of 76 billion dollars, representing $20 \%$ of aggregate investment. ${ }^{3}$ When compared with that of other development banks, the size of BNDES financing becomes even more impressive. For instance, in 2012 the World Bank and the Inter-American Development Bank disbursed 19.8 and 6.9 billion dollars respectively. ${ }^{4}$ In comparison, BNDES financing reached nearly three times their combined disbursements. ${ }^{5}$

While acknowledging that BNDES project analysis involves several other dimensions including social and environmental aspects, this paper focuses on the narrower assessment of the overall impact on the performance of Brazilian firms in terms of productivity. Do BNDES loans help relax credit constraints that hamper productivity growth in Brazilian firms? We address this question by exploiting the unique features of a micro-dataset drawn from a variety of sources: the Annual Industrial Research of the Brazilian Institute of Geography and Statistics; the Annual Social Information Report of the Ministry of Labor; the Foreign Trade Secretary of the Ministry of Industrial Development and Foreign Trade; the Foreign Capital Census and the Central Bank Register of Brazilian Capital Abroad of the Brazilian Central Bank; and BNDES itself. The period covered is $1995-2007 .^{6}$

Our focus on productivity is driven by the fact that, as already discussed, for manufacturing projects the stated aim of long-term BNDES loans is essentially to enhance physical productive efficiency through the economies of scope and scale

\footnotetext{
${ }^{2}$ See De Boulle (2015) for a detailed discussion of how BNDES interest rates are subsidised and their impacts in the credit market.

${ }^{3}$ Information accessed on December 22nd, 2016 at BNDES website (www.bndes.gov.br).

${ }_{5}^{4}$ According to World Bank (2013) and IADB (2013).

${ }^{5}$ In their survey on development banks Luna-Martinez and Vicente (2012) classify BNDES as a 'megabank' together with other large development banks, such as the China Development Bank and Kreditanstalt für Wiederaufbau (KfW) from Germany.

${ }^{6}$ A full description of our data sources is presented in Section 3.
} 
associated with the creation of new plants and the enlargement of existing ones, the restructuring and the modernization of production processes, innovation and technological development. In particular, we consider two measures of productivity: 'total factor productivity' (TFP) and labor productivity. TFP is estimated as the firmlevel Solow residual following the methodology of Levisohn and Petrin (2003). ${ }^{7}$ It measures how effectively a firm transforms a given amount of inputs into output. Labor productivity is computed as the ratio of firm value added to number of employees. Hence, TFP is closer to the long-term concept of physical efficiency whereas labor productivity is more of a short-term concept. ${ }^{8}$

Even though there is a growing literature evaluating government policies for business support (Bronzini and De Blasio, 2006), there is a relative shortage of papers on the specific impact of government policies on private sector development (McKenzie, 2010), especially when it comes to firm productivity (see, e.g., Griliches, Klette and Moen, 2000; Criscuolo, Martin, Overman and Van Reenen, 2016). This is not due to a shortage of methods, since other areas have already developed different ways to deal with the issue. An example can be found in the literature in labor economics that evaluates to what extent government polices affect individuals' achievements (Heckman, LaLonde and Smith, 1999).

In the case of long-term BNDES loans, the specific chain of causation we want to analyse goes from relaxing credit constraints on long-term investment to faster productivity growth. Among the relevant categories of long-term investment, the literature has mostly been interested in those concerning R\&D and innovation. The link between innovation and productivity growth is well established, with some recent

\footnotetext{
${ }^{7}$ Though the methodology by Levinsohn and Petrin (2003) is a standard procedure in the TFP estimation literature, we provide a description in Appendix VI for completeness.

${ }^{8}$ See Bronzini and De Blasio (2006), Criscuolo et al (2016) and Banerjee and Duflo (2014) for assessments in terms of other short-term performance variables such as employment, investment or revenue.
} 
studies showing that as much as $40 \%$ of observed productivity growth can be attributed to R\&D and innovation (Hall, 2011; Reickard, 2011; Syverson, 2011; Hall and Mohen, 2013). However, despite extensive research, empirical findings on the effects of governments' innovation programs are still inconclusive, with results varying a lot across countries (Gao et al, 2016). ${ }^{9}$ The role of credit constraints for innovation and growth has been stressed mainly in the development literature. Banerjee and Duflo (2005) provide evidence that firms in many developing countries face credit constraints, using a sample of countries including Brazil. In the specific case of Brazil, Terra (2003), Aldrighi and Bisinha (2010) and Ambrozio et al (2017) find evidence of credit constraints by investigating the issue at the firm level. More generally, Aghion et al (2010) show that tighter credit constraints discourage firms' long-term investments by increasing the corresponding liquidity risk. In the trade literature, there is also evidence that credit constraints hamper firms' efforts to export (Manova, 2013). According to this paper, there are three mechanisms through which credit constraints affect trade: selection of firms into domestic production; selection of domestic producers into exporting; and, last but not least, how much a firm exports. Results show that credit constraint affect these three mechanisms, especially at the level of firms' exports. In the case of Brazil, it has been found that exporters face lower credit restriction in the Brazilian economy, and even small and middle size firms are not credit constrained if they export a relevant part of their sales (Ambrozio et al, 2017).

BNDES effects on the Brazilian economy have been investigated both in the national and the international literature. Recent examples of the latter include the studies by Bandeira-de-Mello et al (2015), Carvalho (2014) and Bonono et al (2015). Bandeirade-Mello et al (2015) evaluate BNDES loans with reference to a range of firm

\footnotetext{
${ }^{9}$ In the case of Latin American countries, Crespi et al (2014) list a number of papers in which innovation policies are found to have a positive impact on firm performance.
} 
performance indicators, including profitability and investment. Carvalho (2014) investigates whether elections shift investments supported by BNDES towards politically attractive regions. Bonono et al (2015) study whether BNDES loans affect firms' investment. ${ }^{10}$ None of these papers, however, assesses the impact of BNDES financial support on firms' productivity growth, which is the focus of our analysis and one of BNDES policy targets as we argued above.

Closer to the spirit of the present paper, Ottaviano and Lage de Sousa (2008) and Lage de Sousa (2013) investigate the relationship between firms' performance and BNDES loans allocated to the modernization and enlargement of existing plants or to the creation of new ones. ${ }^{11}$ Both papers look only at labor productivity, whereas this paper looks also at TFP. Another feature that distinguishes the present paper is the design of an estimation strategy that not only uses different sets of counterfactual groups but also tests whether granted firms indeed face tougher credit restriction to start with.

Overall, we find that repeatedly granted firms were more credit constrained than comparable non-granted firms before receiving BNDES support. Moreover, with some exception, BNDES support did allow granted firms to match the productivity growth of similar firms that were not credit constrained to start with, but not to outperform them. These findings suggest that government support of the type provided by BNDES may indeed help relax credit constraints that prevent constrained firms from performing as otherwise identical unconstrained ones. On the other hand, they also suggest that BNDES support did not have the effect of making constrained firms select and implement their projects more effectively than unconstrained firms.

\footnotetext{
${ }^{10}$ For the national literature, see the references in Lage de Sousa and Ottaviano (2014).

${ }^{11}$ Coelho and Lage de Sousa (2010) review all previous studies evaluating the effects of BNDES support, including those on productivity. These studies, however, either evaluate BNDES intervention as a whole or types of financial support different from the ones we target.
} 
The rest of the paper is structured as follows. Section 2 details the financial support offered by BNDES to manufacturers. Section 3 introduces the data together with the alternative 'treatment' and 'control' groups we use to assess the impact of BNDES support. Credit constraints are investigated in Section 4, while Section 5 looks at the impact of BNDES support on firm productivity. Section 6 concludes.

\section{Overview of BNDES schemes}

BNDES provides a wide range of financial tools to support Brazilian manufacturing firms: FINEM, Automatic BNDES, FINAME, Leasing FINAME, International Competition FINAME (BNDES-Exim) and Subscription of Securities. BNDES interest rates are subsidized, which means that BNDES reduces firms' marginal cost of investment. We focus on FINEM and Automatic BNDES as these are the most important moneywise as well as the most relevant for productivity enhancing long-term investments. ${ }^{12}$ FINEM ('Financing and Endeavours') is a support scheme for projects with financial needs over 5 million dollars offered by BNDES directly or indirectly through retail banks. Projects with financial needs below this threshold are instead supported solely indirectly through retail banks under the Automatic BNDES scheme. Both schemes contemplate several categories of expenses covering the creation of new plants, the enlargement of existing ones, the restructuring and the modernization of processes, innovation, and technological development. ${ }^{13}$ FINEM and Automatic

\footnotetext{
${ }^{12}$ See Lage de Sousa and Ottaviano (2014) for a detailed discussion of the other types of BNDES financial support; Ribeiro and De Negri (2009) for their effectiveness. Although the other types of financial support are less relevant for our purposes, it will be necessary to account for them in order to isolate the role of FINEM and Automatic BNDES.

${ }^{13}$ Any type of process and/or product innovation is considered an innovation for BNDES. A concrete example of a project supported by FINEM and Automatic BNDES during our period of observation is the development of a new dual fuel engine for cars that can run on gasoline or ethanol. BNDES financed not only research and engineering but also process implementation at the plant. In this case, BNDES financed innovation aimed at reducing carbon dioxide emissions.
} 
BNDES loans are the main types of BNDES financial support, jointly representing nearly half of all BNDES resources. ${ }^{14}$

In order to receive FINEM or Automatic BNDES loans, firms need to send a supporting application form with some brief information of their projects to a retail bank or BNDES itself. The banks evaluate whether the projects are in line with the purpose of the loans. After getting their application approved, firms have to send complete and detailed project plans for in-depth evaluation in terms of whether they are economically viable, what collateral can be used to guarantee the loan, balance sheet and other financial information, and so forth. ${ }^{15}$ All these pieces of information are used to determine whether applicants meet the eligibility criteria for selection as beneficiaries of BNDES support.

If successful, the evaluation process culminates in a formal contract proposal in which the terms and conditions of the loan are established, including amount, period, and interest rate. After negotiations are completed, the loan contract is signed. It is important to note two crucial points here. First, there is an upper limit for BNDES participation in any project. This varies over time but is generally around $80 \%$. A project is thus never fully financed by BNDES. Second, firms receive their loan in instalments according to the development of the project and following a schedule decided during negotiation.

In particular, firms receive the first instalment when the loan is approved and the remaining ones only after an evaluation of the project's progress. Before the second instalment, the firm should prove whether the money of the first disbursement was invested as dictated by the project plan. Any violation of the loan terms leads to a further investigation and instalments are interrupted until justifications are given. If no

\footnotetext{
${ }^{14}$ From 2000 to 2009, FINEM and Automatic BNDES represented on average 46\% of the total BNDES disbursements.

${ }^{15} \mathrm{We}$ will exploit these pieces of information for the construction of the counterfactuals for beneficiaries.
} 
problems emerge, instalments continue until the end of the project. Since these are longterm projects, the period between contract signing and the end of instalments takes on average 5 years. Generally, only after all instalments have been paid, firms start amortizing their loans. The 'conditionality' of instalments to projects' progress and completion implies that granted firms have to invest according to the approved plans so that their credit constraints (if they had any) are almost by definition relaxed by institutional design. An interesting issue then becomes whether they were credit constrained to start with.

\section{Treatment and control groups}

Do FINEM and Automatic BNDES loans help relax credit constraints that hamper the productivity of Brazilian manufacturers? We address this question from a specific angle investigating what would have happened to the granted firms had they not been supported by BNDES but their credit constraints had been nonetheless otherwise removed, making them similar ex post to the non-granted non-credit-constrained firms in the control group also in this respect. ${ }^{16}$ Answering this question requires, first of all, identifying the group of granted ('treated') firms for which enough information is available. Then, it is crucial to define a 'valid' counterfactual. Compared with the counterfactual, one has to establish whether firms granted BNDES loans were indeed credit constrained, and then check whether their productivity actually changed differentially after receiving the BNDES loans. Checking that they have implemented their projects is, instead, redundant given that, as already discussed, BNDES funds are

\footnotetext{
${ }^{16}$ This targets the differential effects of BNDES loans with respect to other sources of finance. From an alternative angle one could investigate what would have happened to the granted firms had they not been supported by BNDES, which would require a comparison group of firms that were not granted but were ex ante similar to the granted firms also in terms of credit constraints. We leave this alternative angle to future research.
} 
transferred to firms in installments and, except for the first one, these are made conditional on firms having successfully followed the agreed implementation plan. ${ }^{17}$

Our analysis relies on micro-data drawn from a variety of sources already used in the papers described by Coelho and Lage de Sousa (2010). In particular, our dataset combines information from: the Annual Industrial Research (Pesquisa Industrial Anual - [PIA]) of the Brazilian Institute of Geography and Statistics (Instituto Brasileiro de Geografia e Estatística - [IBGE]); ${ }^{18}$ the Annual Social Information Report (Relação Anual de Informações Sociais - [RAIS]) of the Ministry of Labor; the Foreign Trade Secretary (Secretaria de Comércio Exterior - [SECEX]) of the Ministry of Industrial Development and Foreign Trade; the Foreign Capital Census and the Central Bank Register of Brazilian Capital Abroad of the Brazilian Central Bank; BNDES itself. ${ }^{19}$

\subsection{Treatment groups}

We select our 'treated' firms as follows. First, we use BNDES data to identify granted firms from 1995 to $2007 .{ }^{20}$ During this period, 756 new firms on average were 'treated' annually in that they received at least once one of the two targeted BNDES financial schemes (FINEM and/or Automatic BNDES). ${ }^{21}$ Nevertheless, it is unfortunately impossible to use all these manufacturers as some of them are not available from PIA, especially small firms. The reason is that PIA covers only around 30,000 firms with more than 30 employees. In total, our beneficiaries represent only $11 \%$ of all manufacturers existent in PIA but around $2 / 3$ of overall manufacturing

\footnotetext{
${ }^{17}$ This would also make it redundant to check whether granted firms are no more credit constrained after receiving BNDES support as long as by design they receive the cash needed to implement their projects.

${ }^{18}$ This survey is our main data source. It contains the majority of the variables useful for this analysis, including those needed to measure firm productivity.

19 The construction of the dataset has followed procedures that guarantee the confidentiality of information so that individual data cannot be related to any specific firm.

${ }^{20}$ Data on 1995 are used only to exclude any firm that received 'financial treatment' in that particular year. Data on 2007 are used to choose one of the counterfactual groups, as described later in the paper.

${ }^{21}$ More precisely, 9,828 firms were granted during these 11 years.
} 
employment. ${ }^{22}$ Hence, the fact that we have to focus only on PIA firms reduces the number of firms granted in our sample by half. Third, the size of the 'treated' group is further reduced because we want to evaluate only the productivity of manufacturing firms granted loans to implement projects in the manufacturing sector. BNDES records, however, concern all manufacturing projects. They thus report also manufacturing projects by non-manufacturing firms (e.g., those of large food retailers investing in the development of their own brands) and do not cover non-manufacturing projects of manufacturing firms (e.g., those implemented in agriculture). Fourth, some firms appear or disappear from records due to mergers. For example, if Firm A received a loan in 1997 and in 2000 merged with Firm B creating a new Firm C, the initial loan should be registered for firm $\mathrm{C}$. As the past records of Firm $\mathrm{C}$ are impossible to reconstruct, we drop all information on loans projects granted to firms like A and $\mathrm{B} .{ }^{23}$ Finally, there is a time lag of generally two to three years before a firm enters the Census part of PIA. ${ }^{24}$ Hence, some granted firms with more than 30 employees are not recorded by PIA at the moment they receive BNDES loans.

Further issues potentially affect the size of our 'treated' group. Some firms are exposed to other government interventions apart from BNDES loans. Since BNDES is the largest financial institution in Brazil offering loans for long-term projects, we assume that its loans are the main type of policy tools affecting firms' productivity. In addition, there may be a time lag for any impact to be detected, since outcomes do not necessarily appear immediately after the loans have been granted or arguably before

\footnotetext{
${ }^{22}$ Firms with less than 30 employees are also considered by PIA, but they are selected randomly for the survey each year. Since their sample varies annually, and is thus impossible to follow, we have decided to discard them. As we will show in Section 3.2.1, BNDES beneficiaries tend to be larger firms. See Bonomo et al (2015) for further analysis on this particular issue.

${ }^{23}$ All firms that have received financial support through Subscription of Securities are deleted from our sample as our focus is on firms implementing projects. Moreover, only a very limited number of firms have received support through Subscription of Securities, which does not provide enough information for any econometric investigation.

${ }^{24}$ IBGE receives information on firms' size (number of employees) for a particular year only at the end of the following year.
} 
they are fully implemented. As some projects last at least five years, we need a period beyond the five-year horizon to assess their impacts not only during but also after implementation. Given the time spanned by our dataset (1996 to 2006), that is clearly not feasible for loans granted from 1999 onwards. On the other hand, as we will discuss later, to construct the 'control' group for firms treated in a certain year, one needs at least two years before treatment. Hence, only for firms granted Automatic BNDES and FINEM loans in 1998 the impacts of these BNDES schemes can be scrutinized both during implementation (from 1998 to 2003) and after implementation (from 2004 to 2006). ${ }^{25}$ Excluding all firms treated before 1998 leaves us with 227 firms which have received the first loan in this specific year (1998). ${ }^{26}$ Among these, 86 firms are not present in the PIA dataset for the whole period investigated. ${ }^{27}$ In the end, we have two initial 'treated' groups: 141 firms and 227 firms, Groups 1 and 2 listed in Table 1, depending on whether we focus only on 'survivors' or not.

Table 1: Number of Treated Firms in 1998

\begin{tabular}{llcc}
\hline Group Name & Description & Survived? & Number of Firms \\
\hline Group 1 & \multirow{2}{*}{ Firms granted for the $1^{\text {st }}$ time in 1998 } & Yes & 141 \\
Group 2 & & No & 227 \\
\hline Group 3 & \multirow{2}{*}{ Firms granted only in1998 } & Yes & 75 \\
Group 4 & & No & 143 \\
\hline Group 5 & \multirow{2}{*}{ Firms granted only Automatic BNDES } & Yes & 112 \\
Group 6 & & No & 190 \\
\hline
\end{tabular}

\footnotetext{
25 Targeting only projects of which the possible impacts can be monitored both during and after implementation (rather than also projects for which monitoring is possible only during implementation) limits the size of the treated groups, and thus the power to detect those impacts. Nevertheless, we have made this choice because full implementation is what is assumed at the project selection stage, and thus the impacts of fully implemented projects are arguably what BNDES support should be eventually held accountable for. Ottaviano and Lage de Sousa (2008) and Lage de Sousa (2013) look only at the effects during implementation (and, as pointed out in the Introduction, only in terms of labor productivity) with treatment year 1997. Their findings are consistent with the ones in the present paper.

${ }^{26}$ Considering that on average 756 firms receive BNDES financial support per year, our reduced sample to 227 firms does not seem to be exceedingly small, especially once we consider that only around half of the granted firms (circa 378 firms) are available in PIA, our main dataset for productivity estimation.

${ }^{27}$ There are three possible explanations for why a firm leaves the PIA dataset: first, it goes bankrupt; second, its employment level falls short of the threshold of 30 employees; third, the main part of its revenue does not come anymore from manufacturing.
} 
On the other hand, it may be useful to further distinguish the firms in these 'treated' groups. First, to see whether there are any differential impacts between FINEM and Automatic BNDES, we consider firms that have received only Automatic BNDES whether surviving (Group 5) or not (Group 6). Second, to investigate the effects of nonrepeated treatment, we also trim our sample to firms that were awarded BNDES support only in 1998 and not afterwards, whether surviving (Group 3) or not (Group 4). ${ }^{28}$

\subsection{Control groups}

As highlighted above, we want to investigate what would have happened to the granted firms had they not been supported by BNDES but still their credit constraints had been otherwise removed. How can we build a 'valid' counterfactual for the selected groups of 'treated' firms? Short of natural experiments or randomized control trials, the answer is not straightforward. We, therefore, try various alternatives in order to control for observable as well as unobservable characteristics using our judgement to identify 'control' groups that are likely to share similar pre-treatment characteristics with the 'treated' ones. Clearly, for the specific purpose of our investigation, credit constraints should not be part of the pre-treatment characteristics we consider and this is made possible by the fact that eligibility to BNDES funding does not require firms to prove they face any credit constraint to start with. We will thus be able to compare ex post 'treated' and 'non-treated' firms that are ex ante similar in several key dimensions apart from credit constraints.

\footnotetext{
${ }^{28}$ We have also investigated different treated groups (such as firms financed through Automatic BNDES only in 1998), but results were similar to those presented for the chosen treated groups.
} 


\subsubsection{Granted versus non-granted}

The first naïve control group (Group A) consists of all 21,380 Brazilian firms (above 30 employees) that did not receive any BNDES loans during the period of analysis. Firms, however, are not randomly selected by BNDES and systematic differences between granted and non-granted firms do exist. Table 2 summarizes the main characteristics of granted and non-granted firms before BNDES intervention. ${ }^{29}$ First, credit constraints seem indeed to be stricter for 'treated' than 'non-treated' firms: whereas cash flow over capital is lower for the former than the latter, the reverse holds for the investment rate (investment over capital). While this is consistent with 'treated' firms facing stricter constraints, it may also be due to the fact that granted firms are more present in riskier sectors, as evidenced by the OECD technological classification.

\begin{tabular}{|c|c|c|c|c|}
\hline Groups & Non-Granted Firms & & Granted Firms & \\
\hline Variables & $\begin{array}{l}\text { All Firms over } 30 \\
\text { employees }\end{array}$ & $\begin{array}{l}\text { All First Time } \\
\text { in } 1998\end{array}$ & $\begin{array}{c}\text { Automatic BNDES } \\
\text { 1st Time } 1998\end{array}$ & $\begin{array}{c}\text { All only in } \\
1998\end{array}$ \\
\hline Labor Productivity & 26.6 & 35.5 & 29.7 & 31.8 \\
\hline Labor Productivity Growth & $30.3 \%$ & $31.7 \%$ & $27.6 \%$ & $34.6 \%$ \\
\hline TFP Levinhson-Petrin & 100 & 115 & 107 & 106 \\
\hline TFP Growth & $-3.2 \%$ & $0.5 \%$ & $-1.6 \%$ & $0.0 \%$ \\
\hline Number of Employees & 175 & 620 & 332 & 468 \\
\hline Investment / Capital & $3.7 \%$ & $6.6 \%$ & $6.9 \%$ & $5.5 \%$ \\
\hline Cash Flow / Capital & $12.3 \%$ & $10.5 \%$ & $10.4 \%$ & $11.2 \%$ \\
\hline Export Status & $32.2 \%$ & $58.9 \%$ & $54.5 \%$ & $49.3 \%$ \\
\hline OCDE Classification & & & & \\
\hline High \& Medium-High Tech & $22 \%$ & $32 \%$ & $32 \%$ & $35 \%$ \\
\hline Low \& Medium-Low Tech & $78 \%$ & $68 \%$ & $68 \%$ & $65 \%$ \\
\hline Number of Firms & 21,380 & 141 & 112 & 75 \\
\hline
\end{tabular}

* All values from 1997

Turning to productivity, on average 'treated' firms are larger and tend to exhibit higher productivity. This is so in terms of both total factor productivity (TFP) and labor productivity (value added per worker), though the difference is more pronounced for the latter. While the labor productivity of firms granted for the first time in 1998 is more

\footnotetext{
${ }^{29}$ Descriptive statistics for the variables in Table 2 can be found in Table A.2 in Appendix II. Variable descriptions and sources are reported in Table A.1 in Appendix I. Similar results are obtained with nonsurviving firms (Groups 2, 4 and 6).
} 
than $30 \%$ higher than that of non-granted firms, the TFP of the former is only $2.6 \%$ higher than that of the latter. Compared with the period before treatment, both measures of productivity grow faster for treated than non-treated firms.

\subsubsection{Observable characteristics}

Differences shown in the previous section suggest a presence of selection bias. By minimizing the differences between 'treated' and 'non-treated' groups in terms of the observable characteristics shown in Table 2, our intention is to reduce this selection bias. In so doing we use a 'mixture' of caliper and one-to-one Propensity Score Matching (PSM). ${ }^{30}$. In pure caliper, matched and non-matched firms are selected with a tolerance defined by the investigator and with replacement. In pure one-to-one PSM, firms are selected as the closest matches without replacement. We 'mix' the two approaches, finding for each treated firm the closest non-treated match without replacement but also imposing a similarity threshold (with tolerance at the $2^{\text {nd }}$ decimal). This method creates a counterfactual group by pairing each granted firm with a similar non-granted one. Treated firms that cannot be paired with any non-granted firm are discarded.

Ideally, to avoid any selection bias, for our specific purposes one would like to compare granted credit-constrained firms with non-granted non-credit-constrained, yet eligible, firms. First, as our dataset allows for the observation of the characteristics of firms that BNDES actually uses to evaluate applications, we can exploit such characteristics. However, characteristics other than those used by BNDES may affect firm productivity growth., To reduce the possible implied bias, as suggested by Caliendo and Kopeinig (2008) and Heinrich, Maffioli and Vasquez (2010), we also

\footnotetext{
${ }^{30}$ See Caliendo and Kopeinig (2008) as well as Heinrich, Maffioli and Vazquez (2010) for further details on how to implement a PSM. See also Arnold and Javornik (2005) for an example of paper using PSM to evaluate the impact of foreign investment on firm productivity in Indonesia.
} 
check whether beneficiaries and non-beneficiaries differ in terms of other observable characteristics, related to firm productivity but different from those relevant for eligibility. Furthermore, there is the issue that unobserved characteristics may drive the decision to apply as well as any ensuing differential productivity growth for granted firms. In this respect, Caliendo, Mahlstet and Mitnick (2014) argue that the unobservable bias can be reduced by increasing the number of covariates. In addition to that, for the evaluation of BNDES effects on productivity we also adopt difference-indifferences conditional on variables that might affect productivity. Finally, as eligibility to BNDES funding does not require applicants to prove they are actually credit constrained, a correct interpretation of results calls for a preliminary check that firms in the treatment groups are indeed more credit constrained than firms in the corresponding control groups before treatment.

As for eligibility criteria, these are unsurprisingly related to the various dimensions through which the lender can try to assess the borrower's ability to repay the loans. A first type of indicator of this ability is the availability of collateral. As firms generally collateralize tangible assets, we measure the availability of collateral through firm capital stock. A second type of indicators relies on the availability of cash flow, which we measure through: revenues; profit over total sales; the ratio of financial costs minus financial revenue to total revenue ('solvency'); and the number of employees as a proxy for firm size alternative to revenue. To control for pre-treatment time trends that Arraiz et al (2014) and Castillo et al (2014) have shown to differ between granted and non-granted firms, we also include the growth rates of revenue, profit and employment. Other indicators considered by BNDES are firms' market share, multinational status and location in terms of whether firms are located in the most developed ('rich') regions of Brazil. These are the South and the Southeast, which jointly represent nearly $85 \%$ of 
Brazilian manufacturing production. Multinational status and location are captured through dummies. Finally, a sectoral dummy is introduced to account for the fact that the BNDES operational structure is divided by sectors.

To identify the indicators that are indeed associated with successful BNDES applications, we use a Probit model in which the outcome is the ex-ante probability of success. The corresponding results are shown in Table 3 for treated Group 1 as defined in Table $1 .{ }^{31}$ All estimated coefficients significantly different from zero have the expected positive sign and the model exhibits reasonable fit, as shown by the percentage of concordance and the Hosmer and Lemeshow Statistic. In particular, performing well pre-treatment (in terms of employment and profit) increases a firm's probability of being supported. Firm size is also important in terms of both the number of employees and revenue. The capital stock matters too when entered together with the number of employees. It is instead insignificant when entered together with revenue. A possible explanation is its weaker correlation with the former than the latter.

\footnotetext{
${ }^{31}$ For parsimony, we present only results related to treatment Group 1. Results for the other treatment groups are available upon request.
} 


\begin{tabular}{lcc}
\hline \multicolumn{3}{c}{ Table 3: Probit Model Results } \\
\hline Probit Model & Employees & Revenues \\
Dependent Variable: BNDES Dummy & $(\mathrm{i})$ & $(\mathrm{ii})$ \\
\hline Capital Stock & 0.08 & 0.06 \\
& $(0.04)^{\star \star}$ & $(0.04)$ \\
Number Employees & 0.17 & \\
& $(0.06)^{\star \star \star}$ & \\
Revenue & & 0.15 \\
& & $(0.05)^{\star \star \star}$ \\
Solvency & -0.96 & -0.86 \\
& $(0.85)$ & $(0.84)$ \\
Profit & -0.58 & -0.71 \\
& $(0.54)$ & $(0.55)$ \\
Profit Growth & 0.07 & 0.08 \\
& $(0.04)^{\star}$ & $(0.04)^{\star}$ \\
Employees Growth & 0.28 & 0.38 \\
& $(0.16)^{\star}$ & $(0.16)^{\star \star}$ \\
Revenue Growth & -0.10 & -0.17 \\
& $(0.14)$ & $(0.14)$ \\
Market Share & 190.87 & 182.76 \\
& $(87.14)^{\star \star}$ & $(87.58)^{\star}$ \\
Multinational Status & -0.10 & -0.17 \\
& $(0.14)$ & $(0.14)$ \\
Rich Region & 0.14 & 0.12 \\
& $(0.13)$ & $(0.13)$ \\
Sector Dummies & Yes & Yes \\
\hline Observations & 5.550 & 5.550 \\
Percent Concordant & $76 \%$ & $76.2 \%$ \\
Hosmer and Lemeshow Statistic ( $p$-value) & 0.86 & 0.74 \\
\hline
\end{tabular}

We can now pair granted and non-granted firms with similar ex-ante probability of being funded (PSM). We start looking for matches at the seventh decimal digit of probability. For unmatched firms we gradually relax the requirement until the second decimal digit. Granted firms that at that point cannot find a non-granted match are dropped. ${ }^{32}$ Starting with all non-granted firms, we find six different 'control' groups depending on each 'treated' group. A summary of how many firms are matched is shown in Table 4 . More than $70 \%$ of treated firms find their non-treated 'twin'. 33

\footnotetext{
${ }^{32}$ More information on PSM results are presented in Appendix III.

${ }^{33}$ Instead of our PSM, we could have used other types of PSM (such as one-to-many or Kernel). These alternatives would have increased the number of matched non-granted firms. They would have reduced, however, the quality of matches. Given that through our PSM more than $70 \%$ of treated firms find their non-treated 'twin', we have preferred to favour match quality. Moreover, Kernel matching is used by
} 


\begin{tabular}{lcccccc}
\hline \multicolumn{7}{c}{ Table 4: Number of Matched Firms } \\
\hline & Group 1 & Group 2 & Group 3 & Group 4 & Group 5 & Group 6 \\
\hline Treated Matched & 118 & 169 & 65 & 108 & 99 & 144 \\
Treated Not Matched & 23 & 58 & 10 & 35 & 13 & 46 \\
\hline Percentage Matched & $84 \%$ & $74 \%$ & $87 \%$ & $76 \%$ & $88 \%$ & $76 \%$ \\
\hline
\end{tabular}

Table 5 illustrates the extent to which matched pairs are similar in terms of the observable characteristics selected through the Probit model. It reports averages for these characteristics as well as t-statistics and p-values for the test of mean difference between matched pairs. ${ }^{34}$ While in the Probit regression all continuous variables are in logs, the averages and the tests of means in Table 5 are in levels, which makes the comparison more telling than in logs as this reduces the variability of variables for matching while allowing it to be larger when testing for balancing.

\begin{tabular}{l|cc|cc|cc}
\hline \multicolumn{7}{c}{ Table 5: Comparing Firms after Matching } \\
\hline & \multicolumn{2}{|c}{ Non-Treated } & \multicolumn{2}{c}{ Treated } & \multicolumn{2}{c}{ Testing Matched Firms } \\
& Not Matched & Matched & Matched & Not Matched & t Value & P-value \\
\hline Capital Stock & 19 & 53 & 66 & 179 & -0.55 & $58.0 \%$ \\
Number of Employees & 192 & 420 & 526 & 1.102 & -1.03 & $30.2 \%$ \\
Solvency & $3.0 \%$ & $2.5 \%$ & $2.7 \%$ & $3.2 \%$ & -0.44 & $66.0 \%$ \\
Profit & $6.7 \%$ & $6.2 \%$ & $6.4 \%$ & $2.0 \%$ & -0.20 & $84.3 \%$ \\
Profit Growth & $49 \%$ & $82 \%$ & $38 \%$ & $125 \%$ & 1.78 & $7.8 \%$ \\
Employment Growth & $4 \%$ & $5 \%$ & $8 \%$ & $14 \%$ & -0.71 & $47.6 \%$ \\
Revenue Growth & $21 \%$ & $21 \%$ & $20 \%$ & $7 \%$ & 0.18 & $85.7 \%$ \\
Market Share & $0.1 \%$ & $0.1 \%$ & $0.2 \%$ & $0.9 \%$ & -1.61 & $11.0 \%$ \\
Multinational Status & $8 \%$ & $11 \%$ & $16 \%$ & $9 \%$ & -1.14 & $25.6 \%$ \\
Rich & $87 \%$ & $87 \%$ & $89 \%$ & $83 \%$ & -0.40 & $68.9 \%$ \\
Labor Productivity & 26.8 & 30.3 & 35.1 & 37.6 & -1.21 & $22.7 \%$ \\
TFP Productivity & 101.7 & 97.1 & 97.1 & 103.3 & 0.04 & $96.6 \%$ \\
Investment & 2.3 & 5.6 & 11.9 & 33.5 & -1.41 & $16.0 \%$ \\
Cash Flow / Capital & $16.8 \%$ & $10.6 \%$ & $10.4 \%$ & $11.4 \%$ & 0.14 & $88.8 \%$ \\
Investment / Capital & $4.0 \%$ & $4.3 \%$ & $6.8 \%$ & $6 \%$ & -3.23 & $0.2 \%$ \\
\hline Number of Firms & 6.226 & 118 & 118 & 23 & & \\
\hline
\end{tabular}

Lage de Sousa (2013), who investigates the effects of our BNDES schemes during (but not after) implementation. His findings are consistent with ours.

${ }^{34}$ For parsimony, in the main text we present only results related to treatment Group 1. Results for the other treatment groups are available in Appendix III. 
In general, treated and non-treated firms are much more alike in Table 5 than in Table 2. At the 5\% level of significance nearly all averages do not exhibit any statistically difference. Most notably, this happens not only for the eligibility-related variables selected through the Probit model, but also for key additional variables (labor productivity, TFP, and cash flow to capital) not included in that model because of their irrelevance for eligibility. As our aim is to measure the impact of BNDES loans on the productivity of beneficiaries, for our purposes it is important that matched firms exhibit similar productivity levels before treatment even though productivity is not used to match them. The same holds for the ratio of cash flow to capital. In this respect, one may argue that, although the investment level remains higher for granted than nongranted firms and overall they still look more credit constrained, their ability to generate funds for investment has become more alike after PSM.

\subsubsection{Unobservable characteristics}

Although beneficiaries and non-beneficiaries are fairly similar in terms of observable characteristics after PSM, differences in terms of unobservable characteristics might still exist so that the problem of selection bias persists. We deal with time-invariant unobservable characteristics by estimating the impact by differencein-differences (more details in Section 5). Then we are left with time-variant unobservable characteristics that might distort our results. Management quality or the capability to generate projects, for instance, are unobservable characteristics that might change over time, especially due to different circumstances faced by firms, such as increased competition or macroeconomic shocks. In order to tackle this issue, we use some observable facts that might affect those unobservable time-variant characteristics. This allows us to design additional control groups to be used for robustness checks. 
There are three observable facts that can be used for this purpose: investment, survival and ability to access BNDES funds. First, as granted firms are among those interested in making investments, we consider the group of all non-granted firms that during the investigated period have both invested and survived. This provides us with a group of firms (Group B) that have managed to invest and remain active during the whole period we investigate, therefore having, for instance, similar management quality and capability to generate projects to those of granted firms. There are 6,344 such firms. Still, for unobservable reasons, these non-granted firms might still not be eligible for BNDES financial support. To deal with this issue, we consider another refined group composed by the firms that did receive BNDES loans but not during the investigated period. The logic behind this is that one may argue that these firms were likely to be eligible for BNDES support during our investigated period but did not apply. Specifically, given that the information we use to test whether BNDES financial support had any impact begins in 1996 and ends in 2006, we place in the refined group (Group C) all firms granted in 2007 for the first time. There are 128 of them. It is important to stress that firms in Group C are contained also in Groups A and B, and firms in Group B also belong to Group A. In other words, our controls groups A, B and C are labelled in increasing order of refinement. ${ }^{35}$

Now that we have identified the 'treatment' and 'control' groups, we are ready to check: whether granted firms are indeed relatively credit constrained before receiving BNDES support; and then how their productivity growth compares with that of other otherwise similar non-granted non-credit constrained firms after receiving BNDES support.

\footnotetext{
${ }^{35}$ Descriptive Statistics for Groups B and C compared with other control and treated groups are available in Table A.2 in Appendix II.
} 


\section{Are granted firms more credit constrained before 'treatment'?}

We investigate credit constraints by looking at the correlation between firms' investment and cash flows. ${ }^{36}$ The underlying idea (we already used to comment on Tables 2 and 5) is that, when firms are credit constrained, investment has to rely on own liquidity thus leading to a positive correlation between investment and cash flow (Fazzari et al 1988). This measure has been criticized by Kaplan and Zingales (1997) among others and alternative approaches have been proposed in the literature, such as that by Almeida et al (2004). ${ }^{37}$ This approach, however, requires information on how much cash each firm has, which unfortunately is not available in our dataset. On the other hand, recent papers following Fazzari et al (1988) -- such as Carpenter and Guariglia (2008), Guariglia (2008) and Guariglia et al (2011) -- show that their idea is still valid for the purpose of investigating credit constraints, especially when information needed to implement other approaches is not available.

Specifically, we test for the presence of credit constraints that are particularly relevant for granted firms by running the following regression:

$$
\operatorname{Inv}_{\mathrm{it}} / \mathrm{K}_{\mathrm{it}-1}=\beta\left(\text { CashFlow }_{\mathrm{it}} / \mathrm{K}_{\mathrm{it}-1}\right)+\alpha\left(\text { CashFlow }_{\mathrm{it}} / \mathrm{K}_{\mathrm{it}-1}\right) * \mathrm{BNDES}_{\mathrm{i}}+\gamma \mathrm{X}_{\mathrm{it}}+\varepsilon_{\mathrm{it}}
$$

where $i$ identifies the firm and $t$ denotes the year, $\operatorname{Inv}_{\text {it }}$ is the level of investment, $\mathrm{K}_{\mathrm{it}-1}$ is the capital stock, CashFlow it is the amount of cash flow generated, BNDES $\mathrm{S}_{\mathrm{i}}$ is a dummy for 'treated' firms, $\mathrm{X}_{\mathrm{it}}$ is a set of controls and $\varepsilon_{\mathrm{it}}$ is the error term. As the capital stock is lagged in time, this specification requires two-period information and, as our treated group includes firms granted in 1998, we are restricted to use information from 1996 and 1997. We are thus able to estimate this specification only with OLS in the cross

\footnotetext{
${ }^{36}$ See Aldrighi and Bisinha (2010), Ambrozio et al (2013), and Terra (2003) for other papers investigating credit restriction using Brazilian firm-level data.

${ }^{37}$ See Ambrozio et al (2013) for additional details.
} 
section. In order to eliminate as much as possible firm specific characteristics, we introduce different sets of dummies, including OECD technological classification, size, region and multinational status, as well as current and lagged sales over capital. For investment opportunities, we follow the literature by including sectoral value added variation and investment. The parameter of interest is $\alpha$. A significant positive estimate would mean that, before receiving BNDES support in 1998, granted firms in treated groups faced indeed stricter credit constraints than non-granted firms in control groups.

Table 6 reports the estimation results based on equation (1) for treated Group 1. Columns correspond to the different counterfactuals. Since the coefficient of cash flow interacted with the BNDES dummy is positive and significant in all entries, the table shows that granted firms are indeed more credit constrained than all control groups before being awarded BNDES financial support. These findings are confirmed also in the case of firms granted Automatic BNDES, but not for those granted only once. ${ }^{38}$ This means that firms that requested BNDES financial support only once were not more credit constrained whereas those that requested it more than once were. Such divergence suggests that repeated treatment can indeed be considered as a marker of a firm being more credit constrained while single treatment cannot. This will enable us to provide a more nuanced picture of how BNDES loans affect relative firm performance depending on the number of treatments.

\footnotetext{
${ }^{38}$ Results for other groups are available in Appendix IV.
} 
Table 6: Credit Restriction for Group 1

\begin{tabular}{|c|c|c|c|c|}
\hline Dependent Variable: Invest / K & $\begin{array}{c}\text { Group A } \\
(1)\end{array}$ & $\begin{array}{c}\text { Group B } \\
(2)\end{array}$ & $\begin{array}{c}\text { Group C } \\
\text { (3) }\end{array}$ & $\begin{array}{c}\text { Paired Firms } \\
\text { (4) }\end{array}$ \\
\hline Cash Flow / K & $\begin{array}{c}0.000816^{\star \star \star} \\
(0.00041)\end{array}$ & $\begin{array}{l}0.000436 \\
(0.00110)\end{array}$ & $\begin{array}{c}-0.00704 \\
(0.0159)\end{array}$ & $\begin{array}{c}0.0508 \\
(0.0394)\end{array}$ \\
\hline BNDES * Cash Flow / K & $\begin{array}{l}0.131^{\star * *} \\
(0.0302)\end{array}$ & $\begin{array}{c}0.128 * \star \star \\
(0.03)\end{array}$ & $\begin{array}{l}0.128^{\star * *} \\
(0.0419)\end{array}$ & $\begin{array}{l}0.120^{\star \star} \\
(0.0532)\end{array}$ \\
\hline Sales / K & $\begin{array}{l}-0.00029 * * * \\
(3.45 e-05)\end{array}$ & $\begin{array}{c}-0.000413^{\star * *} \\
(0.000158)\end{array}$ & $\begin{array}{l}-0.00124 \\
(0.00355)\end{array}$ & $\begin{array}{l}-0.0247^{* * \star} \\
(0.00721)\end{array}$ \\
\hline Sales / $\mathrm{K}$ lagged in time & $\begin{array}{c}0.000352^{\star \star *} \\
(1.96 \mathrm{e}-05)\end{array}$ & $\begin{array}{c}0.000290 * \star \star \\
(2.44 \mathrm{e}-05)\end{array}$ & $\begin{array}{c}0.000518^{\star * \star} \\
(0.000188)\end{array}$ & $\begin{array}{l}0.0168^{* * *} \\
(0.00406)\end{array}$ \\
\hline OCDE Tech. Dummy & Yes & Yes & Yes & Yes \\
\hline Region Dummy & Yes & Yes & Yes & Yes \\
\hline Multinational Dummy & Yes & Yes & Yes & Yes \\
\hline Size Dummy & Yes & Yes & Yes & Yes \\
\hline Observations & 18.104 & 6.485 & 271 & 216 \\
\hline R-squared & 0.111 & 0.132 & 0.215 & 0.181 \\
\hline
\end{tabular}

Standard errors in parentheses

${ }^{* * *} p<0.01,{ }^{* *} p<0.05,{ }^{*} p<0.1$

\section{How do granted firms compare with non-granted firms after 'treatment'?}

After checking that, before accessing BNDES funds, repeatedly granted firms faced more severe credit constraints than non-granted ones, we can now investigate whether BNDES support affected their subsequent relative performance. We do this through a difference-in-differences (DID) approach to eliminate time-invariant unobservable characteristics that are different between 'treated' and 'non-treated' firms. In particular, we adopt the specification in Bronzini and De Blasio (2006):

$y_{i t}=\beta B N D E S_{i}+\sum_{t} \alpha_{t} D_{t}+\sum_{t} \delta_{t}\left(B N D E S_{i} . P O S T_{t}\right)+X_{i t} \gamma+\varepsilon_{i t}$

where $y_{i t}$ is a productivity measure, $B N D E S_{i}$ is a dummy variable indicating granted firms, $D_{t}$ is a year dummy, $P O S T_{t}$ is a set of dummies for each year after the firm received the loan, and $X_{i t}$ is the vector of control variables. The parameter of interest is $\delta_{t}$ : its estimated value measures the differential impact of BNDES support on firm productivity in a given year. Note that the estimation of (2) allows us to assess not only 
whether BNDES support affects firm productivity in general, but also when its impact eventually materializes.

Table 7 presents the estimation results using treatment Groups 1 and 2. Control groups are Group A and paired firms through PSM ('Paired'). Columns of each counterfactual group are divided into two types of productivity measures: labor productivity and total factor productivity (TFP). ${ }^{39}$

\begin{tabular}{|c|c|c|c|c|c|c|c|c|}
\hline \multirow{3}{*}{$\begin{array}{l}\text { Treated Group } \\
\text { Control Group } \\
\text { Dependent Variable }\end{array}$} & \multicolumn{4}{|c|}{ Group 1} & \multicolumn{4}{|c|}{ Group 2} \\
\hline & \multicolumn{2}{|c|}{ Group A } & \multicolumn{2}{|c|}{ Paired } & \multicolumn{2}{|c|}{ Group A } & \multicolumn{2}{|c|}{ Paired } \\
\hline & Labor & TFP & Labor & TFP & Labor & TFP & Labor & TFP \\
\hline \multirow[t]{2}{*}{ Effect in 1998} & $0.130^{\star \star}$ & 0.00176 & 0.103 & 0.00371 & 0.0562 & 0.00904 & 0.0531 & -0.000451 \\
\hline & $(0.0577)$ & $(0.00870)$ & $(0.102)$ & $(0.00319)$ & $(0.0625)$ & $(0.00845)$ & (0.0951) & (0.00176) \\
\hline \multirow[t]{2}{*}{ Effect in 1999} & $0.150^{\star \star \star}$ & -0.00273 & 0.0940 & 0.00188 & 0.0922 & 0.00208 & 0.0838 & -0.00264 \\
\hline & $(0.0549)$ & $(0.00916)$ & $(0.0983)$ & $(0.00291)$ & $(0.0573)$ & $(0.00993)$ & (0.129) & (0.00181) \\
\hline \multirow[t]{2}{*}{ Effect in 2000} & $0.181^{* \star *}$ & -0.0853 & 0.194 & 0.00112 & $0.124^{*}$ & -0.0829 & 0.0589 & -0.00167 \\
\hline & $(0.0562)$ & $(0.0714)$ & $(0.118)$ & $(0.00286)$ & $(0.0665)$ & $(0.0700)$ & $(0.122)$ & (0.00115) \\
\hline \multirow[t]{2}{*}{ Effect in 2001} & $0.163^{\star * *}$ & -0.0115 & $0.195^{\star}$ & 0.00101 & $0.137^{\star \star \star}$ & -0.00943 & -0.00842 & $-0.00216^{*}$ \\
\hline & $(0.0589)$ & (0.0109) & (0.119) & $(0.00278)$ & $(0.0513)$ & (0.0108) & $(0.0757)$ & $(0.00115)$ \\
\hline \multirow[t]{2}{*}{ Effect in 2002} & $0.169^{\star \star \star}$ & $-0.0165^{\star}$ & 0.0724 & 0.00245 & $0.126^{\star \star}$ & -0.0136 & 0.0906 & -0.00113 \\
\hline & $(0.0567)$ & $(0.00976)$ & (0.0736) & $(0.00285)$ & (0.0495) & $(0.00982)$ & (0.0848) & $(0.00126)$ \\
\hline \multirow[t]{2}{*}{ Effect in 2003} & $0.126^{\star \star}$ & -0.0117 & 0.104 & 0.000838 & 0.0703 & -0.00960 & 0.0553 & $-0.00198^{*}$ \\
\hline & (0.0529) & (0.0103) & $(0.0743)$ & $(0.00276)$ & $(0.0500)$ & (0.0114) & (0.0865) & $(0.00113)$ \\
\hline \multirow[t]{2}{*}{ Effect in 2004} & $0.0993^{*}$ & $-0.0269 * *$ & 0.0918 & -0.000126 & 0.0424 & $-0.0259 * *$ & 0.0638 & $-0.00217^{*}$ \\
\hline & (0.0583) & $(0.0125)$ & $(0.0760)$ & $(0.00309)$ & $(0.0537)$ & (0.0131) & (0.0910) & $(0.00120)$ \\
\hline \multirow[t]{2}{*}{ Effect in 2005} & 0.0573 & $-0.0300^{*}$ & 0.0717 & $-6.61 e-05$ & 0.0176 & $-0.0289^{\star}$ & 0.0282 & $-0.00317^{* *}$ \\
\hline & $(0.0587)$ & $(0.0164)$ & $(0.0763)$ & $(0.00307)$ & $(0.0515)$ & (0.0168) & $(0.0856)$ & $(0.00151)$ \\
\hline \multirow[t]{2}{*}{ Effect in 2006} & 0.0122 & $-0.0528^{* * *}$ & 0.0789 & 0.000593 & -0.0216 & 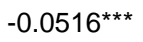 & -0.0242 & $-0.00248^{\star \star}$ \\
\hline & (0.0581) & $(0.0174)$ & $(0.0744)$ & $(0.00276)$ & $(0.0516)$ & (0.0179) & $(0.0800)$ & $(0.00125)$ \\
\hline \multirow[t]{2}{*}{ Multiple Treatments } & 0.00255 & $0.0129 * \star \star$ & 0.0120 & 0.000218 & $0.0182^{\star \star}$ & $0.0137^{\star * \star}$ & $0.0315^{\star \star *}$ & $0.000259 * *$ \\
\hline & $(0.00802)$ & (0.00403) & $(0.0102)$ & (0.000148) & (0.00882) & $(0.00431)$ & (0.00969) & $(0.000121)$ \\
\hline \multirow[t]{2}{*}{ Domestic Capital } & $0.0194^{* \star *}$ & & -0.0217 & & $0.0190 * * *$ & & -0.0156 & \\
\hline & $(0.00450)$ & & (0.0301) & & $(0.00450)$ & & $(0.0326)$ & \\
\hline \multirow[t]{2}{*}{ Imported Capital } & $0.0181^{* *}$ & & $0.0529 * *$ & & $0.0189 * *$ & & 0.0357 & \\
\hline & $(0.00904)$ & & $(0.0225)$ & & (0.00906) & & $(0.0360)$ & \\
\hline Observations & 203.418 & 175.963 & 2.336 & 2.317 & 203.943 & 176.488 & 2.703 & 2.689 \\
\hline R-squared & 0.693 & 0.481 & 0.779 & 0.495 & 0.694 & 0.481 & 0.754 & 0.547 \\
\hline
\end{tabular}

Robust standard errors in parentheses

${ }^{* * *} p<0.01,{ }^{* *} p<0.05,{ }^{*} p<0.1$

As the TFP measure accounts for differences in capital stock among firms, the corresponding regressions do not feature investment in either domestic capital or

\footnotetext{
${ }^{39}$ Outcomes for treated Groups 5 and 6 are very similar to those for Groups 1 and 2 when estimating for control Groups A and Paired. Results are available in Appendix V, together with expanded versions of the tables shown in this section including all covariates.
} 
imported capital as a covariate. ${ }^{40}$ These are, instead, included in the case of labor productivity. Interestingly, investment in imported capital and labor productivity are positively correlated while no clear cut correlation appears in the case of domestic capital. This may suggest that imported capital goods are technologically more advanced.

As for our parameter of interest, in the case of labor productivity results are mixed depending on control groups. In our least refined control group (Groups A), we find a positive impact of BNDES support on labor productivity until 2004 for treatment Group 1 and until 2002 for treatment Group 2. Nonetheless, no effect is evidenced afterwards, suggesting that loans improve the relative performance of granted firms for seven or five years, depending on the treatment group. However, this does not happen when we consider the most refined control groups (Paired). Compared to these groups, 'treated' firms do not perform any different.

Results are not mixed in the case of TFP, in which no effect of BNDES support is detected in the first years after 'treated' firms are granted whatever comparison group is considered. From 2003, BNDES financial support consistently impacts negatively granted firms when compared with non-granted firms in the least refined control Group A no matter whether treated firms survived or not. This holds also for granted firms in the Paired control group when the treated group includes non-survivors (Group 2) but ceases to hold when the treated group consists of survivors only (Group 1). As the most refined comparison between treated Group 1 and control group Paired reveals no differential effect of treatment in terms of both labor productivity and TFP, we conclude that in our sample there is no strong evidence that BNDES support differentially affects firm productivity growth.

\footnotetext{
${ }^{40} \mathrm{We}$ also tried including them but results remained qualitatively similar.
} 
As in Table 7 the number of treatments is positively correlated with firms' productivity, it is relevant to investigate BNDES effects on firms granted only once. ${ }^{41}$ Table 8 shows outcomes for treatment Groups 3 and 4, which are those supported by BNDES only in 1998 and no more until the end of our investigated period (2006). The effects of loans on firms' productivity become less evident for these groups. The positive effect on labor productivity vanishes completely and independently of which control group is considered, from the most naïve (Group A) to the most refined (Paired). This shows that granted firms tend to perform similarly to other firms not only while projects are being implemented but also after their full implementation. In terms of TFP, a negative impact occurs at the end of our investigated period (last two years: 2005 and 2006), yet only when granted firms are compared with the most naïve control group (Group A). The effect disappears completely in the case of paired firms.

\footnotetext{
${ }^{41} \mathrm{We}$ also estimated the model using two strategies for multiple treatments. First, we introduced two dummies: one for firms financed twice to four times; another for firms financed five times or more. Second, we introduced a dummy for each multiple treatment: one for double treatment, another for triple treatment, and so on. All estimations remained similar to those we report and are available upon request.
} 


\begin{tabular}{|c|c|c|c|c|c|c|c|c|}
\hline \multicolumn{9}{|c|}{ Table 8: Results of Difference-in-Differences (Just Once) } \\
\hline \multirow{3}{*}{$\begin{array}{l}\text { Treated Group } \\
\text { Control Group } \\
\text { Dependent Variable }\end{array}$} & \multicolumn{4}{|c|}{ Group 3} & \multicolumn{4}{|c|}{ Group 4} \\
\hline & \multicolumn{2}{|c|}{ Group A } & \multicolumn{2}{|c|}{ Paired } & \multicolumn{2}{|c|}{ Group A } & \multicolumn{2}{|c|}{ Paired } \\
\hline & Labor & TFP & Labor & TFP & Labor & TFP & Labor & TFP \\
\hline Effect in 1998 & $\begin{array}{c}0.0261 \\
(0.0822)\end{array}$ & $\begin{array}{c}0.0194^{\star *} \\
(0.00868)\end{array}$ & $\begin{array}{c}0.00939 \\
(0.104)\end{array}$ & $\begin{array}{l}-0.0165 \\
(0.0174)\end{array}$ & $\begin{array}{c}0.0493 \\
(0.0902)\end{array}$ & $\begin{array}{c}0.0119 \\
(0.0109)\end{array}$ & $\begin{array}{c}0.113 \\
(0.135)\end{array}$ & $\begin{array}{r}-0.000821 \\
(0.00237)\end{array}$ \\
\hline Effect in 1999 & $\begin{array}{c}0.0508 \\
(0.0722)\end{array}$ & $\begin{array}{c}0.00920 \\
(0.00931)\end{array}$ & $\begin{array}{l}-0.0456 \\
(0.103)\end{array}$ & $\begin{array}{l}-0.00399 \\
(0.00354)\end{array}$ & $\begin{array}{c}0.0763 \\
(0.0821)\end{array}$ & $\begin{array}{l}0.00202 \\
(0.0121)\end{array}$ & $\begin{array}{l}0.0163 \\
(0.158)\end{array}$ & $\begin{array}{l}-0.00253 \\
(0.00253)\end{array}$ \\
\hline Effect in 2000 & $\begin{array}{c}0.0432 \\
(0.0972)\end{array}$ & $\begin{array}{l}-0.0759 \\
(0.0724)\end{array}$ & $\begin{array}{c}-0.0694 \\
(0.109)\end{array}$ & $\begin{array}{r}-0.000177 \\
(0.00291)\end{array}$ & $\begin{array}{c}0.0730 \\
(0.1000)\end{array}$ & $\begin{array}{l}-0.0825 \\
(0.0706)\end{array}$ & $\begin{array}{l}-0.0322 \\
(0.163)\end{array}$ & $\begin{array}{l}-0.00112 \\
(0.00135)\end{array}$ \\
\hline Effect in 2001 & $\begin{array}{c}0.0752 \\
(0.0559)\end{array}$ & $\begin{array}{l}-0.00510 \\
(0.0101)\end{array}$ & $\begin{array}{c}-0.0422 \\
(0.112)\end{array}$ & $\begin{array}{l}-0.00177 \\
(0.00293)\end{array}$ & $\begin{array}{c}0.108 \\
(0.0721)\end{array}$ & $\begin{array}{l}-0.0111 \\
(0.0123)\end{array}$ & $\begin{array}{l}-0.0578 \\
(0.105)\end{array}$ & $\begin{array}{l}-0.00149 \\
(0.00137)\end{array}$ \\
\hline Effect in 2002 & $\begin{array}{c}0.0710 \\
(0.0510)\end{array}$ & $\begin{array}{c}-0.0106 \\
(0.00908)\end{array}$ & $\begin{array}{l}0.0728 \\
(0.103)\end{array}$ & $\begin{array}{r}-5.14 e-05 \\
(0.00304)\end{array}$ & $\begin{array}{c}0.109 \\
(0.0681)\end{array}$ & $\begin{array}{l}-0.0159 \\
(0.0116)\end{array}$ & $\begin{array}{l}0.0471 \\
(0.117)\end{array}$ & $\begin{array}{l}0.000458 \\
(0.00166)\end{array}$ \\
\hline Effect in 2003 & $\begin{array}{c}0.0608 \\
(0.0516)\end{array}$ & $\begin{array}{c}-0.000425 \\
(0.0121)\end{array}$ & $\begin{array}{c}0.121 \\
(0.103)\end{array}$ & $\begin{array}{r}-0.000950 \\
(0.00273)\end{array}$ & $\begin{array}{c}0.102 \\
(0.0668)\end{array}$ & $\begin{array}{c}-0.00522 \\
(0.0144)\end{array}$ & $\begin{array}{c}0.142 \\
(0.118)\end{array}$ & $\begin{array}{r}-0.000398 \\
(0.00135)\end{array}$ \\
\hline Effect in 2004 & $\begin{array}{c}0.0246 \\
(0.0589)\end{array}$ & $\begin{array}{c}-0.0204 \\
(0.0127)\end{array}$ & $\begin{array}{c}0.168 \\
(0.117)\end{array}$ & $\begin{array}{c}5.31 \mathrm{e}-05 \\
(0.00289)\end{array}$ & $\begin{array}{c}0.0702 \\
(0.0713)\end{array}$ & $\begin{array}{l}-0.0244 \\
(0.0157)\end{array}$ & $\begin{array}{l}0.0938 \\
(0.125)\end{array}$ & $\begin{array}{r}-0.000715 \\
(0.00148)\end{array}$ \\
\hline Effect in 2005 & $\begin{array}{c}0.0122 \\
(0.0498)\end{array}$ & $\begin{array}{l}-0.0272^{*} \\
(0.0153)\end{array}$ & $\begin{array}{c}0.117 \\
(0.112)\end{array}$ & $\begin{array}{l}0.001000 \\
(0.00301)\end{array}$ & $\begin{array}{c}0.0626 \\
(0.0652)\end{array}$ & $\begin{array}{l}-0.0305^{\star} \\
(0.0180)\end{array}$ & $\begin{array}{l}0.0483 \\
(0.107)\end{array}$ & $\begin{array}{c}-0.00234 \\
(0.00201)\end{array}$ \\
\hline Effect in 2006 & $\begin{array}{l}-0.0647 \\
(0.0567)\end{array}$ & $\begin{array}{c}-0.0535^{\star \star *} \\
(0.0165)\end{array}$ & $\begin{array}{l}0.0128 \\
(0.117)\end{array}$ & $\begin{array}{l}-0.00271 \\
(0.00291)\end{array}$ & $\begin{array}{l}-0.0138 \\
(0.0709)\end{array}$ & $\begin{array}{c}-0.0567^{\star \star \star} \\
(0.0187)\end{array}$ & $\begin{array}{l}0.0195 \\
(0.115)\end{array}$ & $\begin{array}{r}-0.000935 \\
(0.00151)\end{array}$ \\
\hline Imported Capital & $\begin{array}{c}0.0196 * \star \star \\
(0.00450) \\
0.0186^{\star \star} \\
(0.00907)\end{array}$ & & $\begin{array}{c}-0.0182 \\
(0.0300) \\
0.000187 \\
(0.0319) \\
\end{array}$ & & $\begin{array}{c}0.0196 * * * \\
(0.00450) \\
0.0187^{* *} \\
(0.00907)\end{array}$ & & $\begin{array}{c}0.0855^{\star} \\
(0.0491) \\
0.0627 \\
(0.0451)\end{array}$ & \\
\hline $\begin{array}{l}\text { Observations } \\
\text { R-squared }\end{array}$ & $\begin{array}{c}203.128 \\
0.693\end{array}$ & $\begin{array}{c}175.677 \\
0.11\end{array}$ & $\begin{array}{l}1.203 \\
0.870\end{array}$ & $\begin{array}{l}1.189 \\
0.191\end{array}$ & $\begin{array}{c}203.150 \\
0.693\end{array}$ & $\begin{array}{c}175.696 \\
0.481\end{array}$ & $\begin{array}{l}1.674 \\
0.761\end{array}$ & $\begin{array}{l}1.661 \\
0.391\end{array}$ \\
\hline
\end{tabular}

Robust standard errors in parentheses

${ }^{* * *} p<0.01,{ }^{* *} p<0.05,{ }^{*} p<0.1$

The existence of unobserved time-variant characteristics, which are not considered in the previous estimations, might be interfering in the overall results. As a robustness check, we estimate the effect of these schemes using the two control groups described in Section 4: non-granted firms that have both invested and survived (Group B) and, among those, all firms granted in 2007 for the first time (Group C). As these control groups include only surviving firms, we consider only granted firms that have also survived during the investigated period: treatment Groups 1, 3 and 5. Table 9 shows the results. Columns present a similar structure as in previous tables and, while different control groups are used, the message remains basically the same. A positive impact on labor productivity occurs in all three treated groups when we use the less 
refined control Group B but disappears when we look at the more refined control Group C. Once more, there is little evidence that BNDES support differentially affects firm productivity growth also after controlling for the existence of unobserved time-variant characteristics.

These findings are not an isolated case in the literature. For example, Criscuolo et al (2016) investigate the effect of industrial policy in the UK. Their results show no significant impact on firms' productivity, even though there are effects on employment and investment. Arraiz et al (2014) evaluate the effects of government-backed partial credit guarantees on firms' performance in Colombia. Although they find some impact on output and employment, no effect is found on productivity. Similar outcomes are also reported by other papers listed in Coelho and Lage de Sousa (2010), including Ottaviano and Lage de Sousa (2008) and Lage de Sousa (2013). These last two papers investigate the same BNDES schemes as we do here but use different empirical strategies and a different granted year (1997), which suggests that our results may hold regardless of the year investigated. Given that Lage de Sousa (2013) use Kernel matching strategy, our results also seem robust across different matching strategies. 


\begin{tabular}{|c|c|c|c|c|c|c|c|c|c|c|c|c|}
\hline \multirow{3}{*}{$\begin{array}{l}\text { Treated Group } \\
\text { Control Group } \\
\text { Dependent Variable }\end{array}$} & \multicolumn{4}{|c|}{ Group 1} & \multicolumn{4}{|c|}{ Group 3} & \multicolumn{4}{|c|}{ Group 5} \\
\hline & \multicolumn{2}{|c|}{ Group B } & \multicolumn{2}{|c|}{ Group C } & \multicolumn{2}{|c|}{ Group B } & \multicolumn{2}{|c|}{ Group C } & \multicolumn{2}{|c|}{ Group B } & \multicolumn{2}{|c|}{ Group C } \\
\hline & Labor & TFP & Labor & TFP & Labor & TFP & Labor & TFP & Labor & TFP & Labor & TFP \\
\hline Effect in 1998 & $\begin{array}{l}0.0943^{\star} \\
(0.0565)\end{array}$ & $\begin{array}{c}0.0162 \\
(0.0451)\end{array}$ & $\begin{array}{c}0.180 \\
(0.156)\end{array}$ & $\begin{array}{c}0.0211 \\
(0.0649)\end{array}$ & $\begin{array}{c}0.129 \\
(0.0865)\end{array}$ & $\begin{array}{c}0.0173 \\
(0.0648)\end{array}$ & $\begin{array}{c}0.230 \\
(0.168)\end{array}$ & $\begin{array}{c}0.0197 \\
(0.0791)\end{array}$ & $\begin{array}{c}0.105 \\
(0.0647)\end{array}$ & $\begin{array}{c}0.0217 \\
(0.0497)\end{array}$ & $\begin{array}{c}0.189 \\
(0.158)\end{array}$ & $\begin{array}{c}0.0239 \\
(0.0684)\end{array}$ \\
\hline Effect in 1999 & $\begin{array}{c}0.109^{\star *} \\
(0.0533)\end{array}$ & $\begin{array}{l}-0.0210 \\
(0.0431)\end{array}$ & $\begin{array}{l}0.0303 \\
(0.123)\end{array}$ & $\begin{array}{l}-0.0227 \\
(0.0609)\end{array}$ & $\begin{array}{c}0.133^{\star} \\
(0.0802)\end{array}$ & $\begin{array}{l}-0.0159 \\
(0.0608)\end{array}$ & $\begin{array}{l}0.0578 \\
(0.137)\end{array}$ & $\begin{array}{l}-0.0279 \\
(0.0735)\end{array}$ & $\begin{array}{l}0.121^{\star *} \\
(0.0594)\end{array}$ & $\begin{array}{l}-0.0196 \\
(0.0456)\end{array}$ & $\begin{array}{l}0.0444 \\
(0.126)\end{array}$ & $\begin{array}{l}-0.0215 \\
(0.0626)\end{array}$ \\
\hline Effect in 2000 & $\begin{array}{c}0.130^{\star \star} \\
(0.0550)\end{array}$ & $\begin{array}{l}-0.0185 \\
(0.0442)\end{array}$ & $\begin{array}{l}0.0742 \\
(0.158)\end{array}$ & $\begin{array}{l}-0.0383 \\
(0.0613)\end{array}$ & $\begin{array}{c}0.106 \\
(0.0854)\end{array}$ & $\begin{array}{l}-0.0333 \\
(0.0621)\end{array}$ & $\begin{array}{l}0.0461 \\
(0.172)\end{array}$ & $\begin{array}{l}-0.0676 \\
(0.0746)\end{array}$ & $\begin{array}{c}0.146^{\star \star} \\
(0.0595)\end{array}$ & $\begin{array}{l}-0.0266 \\
(0.0472)\end{array}$ & $\begin{array}{l}0.0845 \\
(0.160)\end{array}$ & $\begin{array}{l}-0.0457 \\
(0.0631)\end{array}$ \\
\hline Effect in 2001 & $\begin{array}{l}0.128^{\star *} \\
(0.0574)\end{array}$ & $\begin{array}{l}-0.0276 \\
(0.0415)\end{array}$ & $\begin{array}{c}0.281 \\
(0.199)\end{array}$ & $\begin{array}{l}0.00854 \\
(0.0587)\end{array}$ & $\begin{array}{c}0.0971 \\
(0.0891)\end{array}$ & $\begin{array}{l}-0.0568 \\
(0.0603)\end{array}$ & $\begin{array}{c}0.258 \\
(0.210)\end{array}$ & $\begin{array}{l}-0.0335 \\
(0.0730)\end{array}$ & $\begin{array}{l}0.127^{\star \star} \\
(0.0614)\end{array}$ & $\begin{array}{l}-0.0375 \\
(0.0461)\end{array}$ & $\begin{array}{c}0.281 \\
(0.201)\end{array}$ & $\begin{array}{c}0.000887 \\
(0.0617)\end{array}$ \\
\hline Effect in 2002 & $\begin{array}{l}0.153^{\star * \star} \\
(0.0550)\end{array}$ & $\begin{array}{c}0.0224 \\
(0.0442)\end{array}$ & $\begin{array}{c}0.182 \\
(0.130)\end{array}$ & $\begin{array}{c}0.0121 \\
(0.0624)\end{array}$ & $\begin{array}{c}0.135 \\
(0.0845)\end{array}$ & $\begin{array}{c}0.0168 \\
(0.0650)\end{array}$ & $\begin{array}{c}0.175 \\
(0.146)\end{array}$ & $\begin{array}{l}-0.00557 \\
(0.0774)\end{array}$ & $\begin{array}{l}0.141^{\star \star} \\
(0.0612)\end{array}$ & $\begin{array}{l}0.00287 \\
(0.0492)\end{array}$ & $\begin{array}{c}0.167 \\
(0.132)\end{array}$ & $\begin{array}{l}-0.0108 \\
(0.0656)\end{array}$ \\
\hline Effect in 2003 & $\begin{array}{l}0.123^{\star *} \\
(0.0511)\end{array}$ & $\begin{array}{l}-0.0284 \\
(0.0450)\end{array}$ & $\begin{array}{l}-0.0456 \\
(0.106)\end{array}$ & $\begin{array}{l}-0.0402 \\
(0.0606)\end{array}$ & $\begin{array}{c}0.141^{*} \\
(0.0779)\end{array}$ & $\begin{array}{l}-0.0391 \\
(0.0630)\end{array}$ & $\begin{array}{l}-0.0240 \\
(0.122)\end{array}$ & $\begin{array}{l}-0.0647 \\
(0.0741)\end{array}$ & $\begin{array}{c}0.102^{\star} \\
(0.0590)\end{array}$ & $\begin{array}{l}-0.0347 \\
(0.0500)\end{array}$ & $\begin{array}{l}-0.0727 \\
(0.110)\end{array}$ & $\begin{array}{l}-0.0507 \\
(0.0641)\end{array}$ \\
\hline Effect in 2004 & $\begin{array}{c}0.113^{\star \star} \\
(0.0561)\end{array}$ & $\begin{array}{l}-0.0184 \\
(0.0429)\end{array}$ & $\begin{array}{l}-0.0556 \\
(0.108)\end{array}$ & $\begin{array}{l}-0.0598 \\
(0.0620)\end{array}$ & $\begin{array}{c}0.132^{\star} \\
(0.0801)\end{array}$ & $\begin{array}{l}-0.0256 \\
(0.0611)\end{array}$ & $\begin{array}{l}-0.0231 \\
(0.122)\end{array}$ & $\begin{array}{l}-0.0854 \\
(0.0752)\end{array}$ & $\begin{array}{c}0.0968 \\
(0.0655)\end{array}$ & $\begin{array}{l}-0.00373 \\
(0.0475)\end{array}$ & $\begin{array}{l}-0.0746 \\
(0.112)\end{array}$ & $\begin{array}{l}-0.0529 \\
(0.0653)\end{array}$ \\
\hline Effect in 2005 & $\begin{array}{c}0.0875 \\
(0.0563)\end{array}$ & $\begin{array}{l}-0.0462 \\
(0.0417)\end{array}$ & $\begin{array}{l}-0.0822 \\
(0.108)\end{array}$ & $\begin{array}{l}-0.0574 \\
(0.0612)\end{array}$ & $\begin{array}{c}0.117 \\
(0.0796)\end{array}$ & $\begin{array}{l}-0.0547 \\
(0.0595)\end{array}$ & $\begin{array}{l}-0.0376 \\
(0.121)\end{array}$ & $\begin{array}{l}-0.0796 \\
(0.0735)\end{array}$ & $\begin{array}{c}0.0763 \\
(0.0658)\end{array}$ & $\begin{array}{l}-0.0321 \\
(0.0467)\end{array}$ & $\begin{array}{l}-0.101 \\
(0.113)\end{array}$ & $\begin{array}{l}-0.0494 \\
(0.0642)\end{array}$ \\
\hline Effect in 2006 & $\begin{array}{c}0.0600 \\
(0.0563)\end{array}$ & $\begin{array}{l}-0.0636 \\
(0.0439)\end{array}$ & $\begin{array}{l}-0.104 \\
(0.107)\end{array}$ & $\begin{array}{l}-0.115^{*} \\
(0.0642)\end{array}$ & $\begin{array}{c}0.0608 \\
(0.0868)\end{array}$ & $\begin{array}{l}-0.0815 \\
(0.0629)\end{array}$ & $\begin{array}{l}-0.0978 \\
(0.125)\end{array}$ & $\begin{array}{l}-0.144^{*} \\
(0.0783)\end{array}$ & $\begin{array}{c}0.0707 \\
(0.0649)\end{array}$ & $\begin{array}{l}-0.0534 \\
(0.0486)\end{array}$ & $\begin{array}{l}-0.102 \\
(0.111)\end{array}$ & $\begin{array}{l}-0.111^{*} \\
(0.0671)\end{array}$ \\
\hline Multiple Treatments & $\begin{array}{c}0.00657 \\
(0.00782)\end{array}$ & $\begin{array}{l}-0.0138^{*} \\
(0.00712)\end{array}$ & $\begin{array}{c}0.0136 \\
(0.00915)\end{array}$ & $\begin{array}{l}-0.00822 \\
(0.00752)\end{array}$ & & & & & $\begin{array}{c}0.0144 \\
(0.0104)\end{array}$ & $\begin{array}{l}-0.00783 \\
(0.00890)\end{array}$ & $\begin{array}{c}0.0176 \\
(0.0112)\end{array}$ & $\begin{array}{c}-0.0124 \\
(0.00881)\end{array}$ \\
\hline Imported Capital & $\begin{array}{c}-0.0147^{\star \star \star} \\
(0.00568) \\
0.0143 \\
(0.00900)\end{array}$ & & $\begin{array}{l}-0.144^{\star * \star} \\
(0.0394) \\
0.0770^{\star \star} \\
(0.0319)\end{array}$ & & $\begin{array}{c}-0.0138^{\star \star} \\
(0.00570) \\
0.0142 \\
(0.00902)\end{array}$ & & $\begin{array}{l}-0.119 * \star \\
(0.0478) \\
0.0949 \star * \\
(0.0415)\end{array}$ & & $\begin{array}{c}-0.0148^{\star \star \star} \\
(0.00569) \\
0.0144 \\
(0.00900)\end{array}$ & & $\begin{array}{l}-0.154^{\star \star *} \\
(0.0416) \\
0.0811^{\star \star} \\
(0.0359)\end{array}$ & \\
\hline Observations & 78,137 & 76,878 & 2.698 & 2,674 & 77,479 & 76,220 & 2,040 & 2,016 & 77,847 & 76,592 & 2.408 & 2,388 \\
\hline R-squared & 0.707 & 0.445 & 0.694 & 0.446 & 0.705 & 0.445 & 0.653 & 0.457 & 0.705 & 0.445 & 0.664 & 0.439 \\
\hline
\end{tabular}




\section{Concluding remarks}

We have addressed the question whether FINEM and Automatic BNDES loans help relax credit constraints hampering the productivity of Brazilian manufacturers from the perspective of what would have happened to the granted firms had they not been supported by BNDES but their credit constraints had been nonetheless otherwise removed. In so doing, we have taken a difference-in-differences approach carefully evaluating alternative treatment and control groups. We have first checked whether firms granted BNDES loans were indeed credit constrained before treatment and found supportive evidence for firms that were granted more than once. We have then looked at productivity growth and found that, by giving granted firms the resources to implement their projects, BNDES support has allowed them to perform like otherwise similar noncredit-constrained non-granted firms. On the other hand, firms that have requested financial support only once do not seem to be credit constrained before being granted, and perform similarly to those non-granted after receiving government support.

Overall, our findings suggest that credit constraints facing Brazilian manufacturing firms are real, at least for firms that apply to BNDES repeatedly and BNDES funding has allowed beneficiaries to match the performance of similar unconstrained firms in terms of productivity but not to outperform them.

These findings have important policy implications. Government support of the type provided by BNDES can allow credit constrained firms to perform as otherwise similar unconstrained ones. It might also increase firm average productivity by making constrained firms more productive than they would otherwise be. There is, however, no evidence that this type of government support can make firms choose better projects than they would choose on their own in the absence of credit constraints. 
In the trade literature with heterogeneous firms, only the most productive firms are able to export (see, e.g., Melitz, 2013, and Melitz and Ottaviano, 2008). Therefore, productivity improvements are required to enter the international market. Credit constraints make it difficult for firms to raise their performance and consequently to export. Our paper contributes to the literature by showing that removing firms' credit constraint enables firms to perform similar to unconstrained firms. As a consequence, firms become capable to export. In our study, $10 \%$ of the beneficiaries started to export after being granted, and their export growth was 50\% higher than Brazilian total export growth. Understanding the links between credit restriction, productivity improvements and export performance remains a promising direction for future research in international trade. 


\section{References}

Aghion, P., Angeletos, G. M., Banerjee, A., and Manova, K. (2010) "Volatility and growth: Credit constraints and the composition of investment" Journal of Monetary Economics, Vol. 57(3), 246-265.

Aldrighi, D. M. and Bisinha, R. (2010) "Restrição financeira em empresas com ações negociadas na Bovespa" Revista Brasileira de Economia, Vol. 64 (no. 1): pages 25-47. Almeida, H., Campello, M. and Weisbach, M.S. (2004) "The cash flow sensitivity of cash" The Journal of Finance, 59(4), 1777-1804.

Ambrozio, A. H. P., Faleiros, J. P., Lage de Sousa, F. L. and Sant'Anna, A. (2017) "Credit Scarcity in Developing Countries: An Empirical Investigation Using Brazilian Firm-Level Data" EconomiA, 18(1), 73-87.

Arnold, J. M., and Javorcik, B.S. (2009). "Gifted kids or pushy parents? Foreign direct investment and plant productivity in Indonesia." Journal of International Economics, $79(1), 42-53$.

Arráiz, I., Meléndez, M. and Stucchi, R. (2014) "Partial credit guarantees and firm performance: evidence from Colombia" Small Business Economics, 43(3), 711-724.

Bandeira-de-Mello, R., Lazzarini, S. G., Musacchio, A. and Marcon, R. (2015). "What Do State-Owned Development Banks Do? Evidence from BNDES, 2002-09.” World Development, 66, 237-253.

Banerjee, A. V. and Duflo, E. (2005) "Growth Theory Through the Lens of Development Economics" Economics Handbook of Economic Growth, Vol. 1, Part A: pages $473-552$.

Banerjee, A. V. and Duflo, E. (2014) "Do firms want to borrow more? Testing credit constraints using a directed lending program” The Review of Economic Studies, 81(2), $572-607$. 
Bonomo, M., Brito, R., \& Martins, B. (2015) "Macroeconomic and Financial Consequences of the Post-Crisis Government-Driven Credit Expansion in Brazil" The Journal of International Money and Finance, 55, pp; 11-34

Bronzini, R. and De Blasio, G. (2006) "Evaluating the impact of investments incentives: The case of the Italian Law 488/1992" Journal of Urban Economics, Vol. 60 (no. 2): pages $327-349$.

Carballo, J., Schaur, G., \& Volpe Martincus, C. (2016) "Trust No One?: Security and International Trade” IADB Working Paper Series, No. 703, June.

Carpenter, R. and Guariglia, A. (2008) "Cash flow, investment, and investment opportunities: new tests using UK panel data" Journal of Banking and Finance, Vol. 32 (no. 9): pages 1894-1906.

Caliendo, M., and Kopeinig, S. (2008) "Some practical guidance for the implementation of propensity score matching” Journal of economic surveys, 22(1), 31-72.

Caliendo, M., Mahlstedt, R., \& Mitnik, O. A. (2014). “Unobservable, but Unimportant? The Influence of Personality Traits (and Other Usually Unobserved Variables) for the Evaluation of Labor Market Policies” IZA Discussion Paper, No. 8337, July.

Carvalho, D. (2014) “The Real Effects of Government-Owned Banks: Evidence from an Emerging Market" The Journal of Finance, 69(2), 577-609.

Castillo, V., Maffioli, A., Rojo, S. and Stucchi, R. (2014) "The effect of innovation policy on SMEs' employment and wages in Argentina" Small Business Economics, 42(2), 387-406.

Coelho, D. and Lage de Sousa, F.L. (2010) "Os Efeitos dos Financiamentos do BNDES sobre o Desempenho das Empresas Industriais Brasileiras" in Estrutura Produtiva $\underline{\text { Avançada e Regionalmente Integrada: Desafios do Desenvolvimento Produtivo }}$ Brasileiro, Livro 5, Vol. 1, edited by De Negri, F. and Almeida, M., IPEA, Brasília. 
De Bolle, M. (2015). “Do Public Development Banks Hurt Growth? Evidence from Brazil.” Peterson Institute for International Economics Policy Brief, Number PB15-16. Gao, D., Guo, Y. and Jiang (2016) "Government-subsidized R\&D and firm innovation:Evidence from China" Research Policy, 45, 1129-1144.

Crespi, G., Maffioli A. and Rastelletti, R. (2014) "Investing in Ideas: Policies to Foster Innovation" in Rethinking Productive Development: Sound Policies and Institutions for Economic Transformation. Ed. Eduardo Fernandez Arias, Gustavo Crespi, Ernesto Stein. Washington, DC: Palgrave Macmillan.

Criscuolo, C., Martin, R., Overman, H. G. and Van Reenen, J. (2016) "The causal effects of an industrial policy" CEP Discussion Paper No. 1113, London School of Economics and Political Science, London, UK.

Fazzari, S., Hubbard, R. and Petersen, B. (1988) "Financing constraints and corporate investments” Brookings Papers on Economic Activity (no. 1): pages 141-206.

Guariglia, A. (2008) "Internal financial constraints, external financial constraints, and investment choice: evidence from a panel of UK firms" Journal of Banking and Finance, Vol. 32: pages 1795-1809.

Guariglia, A., Liu, X. and Song, L. (2011) "Internal finance and growth: microeconometric evidence on Chinese firms" Journal of Development Economics, Vol. 96 (no. 1): pages 79-94.

Grilliches, Z., Klette, T. J. and Moen, J. (2000). "Do subsidies to commercial R\&D reduce market failures? Microeconometric evaluation studies” Research Policy, Vol. 29 (no. 4\&5): pages 471-495.

Hall, B.H. (2011) “Innovation and productivity” Nordic Economic Policy Review, Vol. 2: $167-204$. 
Hall, B. H. and Mohnen, P. (2013) "Innovation and productivity: an update" Eurasian Business Review, Vol. 3(1): 47-65.

Heckman, J. J., LaLonde R. J. and J.A. Smith (1999) "The Economics and Econometrics of Active Labor Market Programs." in Handbook of Labor Economics edited by O. Ashenfelter, D. E. Card and D. Card, Elsevier. Vol. 3: pages 1865-2097. IADB (2013) “Annual Report 2013: The Year in Review” Washington, DC.

Kaplan, S. N. and Zingales, L. (1997) "Do investment-cash flow sensitivities provide useful measures of financing constraints?” Quarterly Journal of Economics, 169-215. Lage de Sousa, F. (2013) “How Can Development Banks Boost Firms’ Productivity?" in Development Evaluation in Times of Turbulence: Dealing with Crises that Endanger our Future edited by Ray Rist, Marie-Hélène Boily and Frederic Martin, World Bank, Washington DC.

Lage de Sousa, F. and Ottaviano, G. (2014) "Relaxing credit constraints in emerging economies: The impact of public loans on the performance of Brazilian manufacturers", Centre for Economic Policy Research, Discussion Paper n.1309.

Levinsohn, J., and Petrin, A. (2003) "Estimating production functions using inputs to control for unobservables" The Review of Economic Studies, Vol. 70(no. 2): pages 317 341.

Lopez-Cordova and Moreira (2003) "Regional Integration and Productivity: The Experiences of Brazil and Mexico" BID-Intal-ITD-STA Working Paper, No. 14, Washington, DC.

Luna-Martinez, D. and Vicente, C. L. (2012) "Global survey of development banks" World Bank Policy Research Working Paper n.5969.

Manova, K. (2013) "Credit constraints, heterogeneous firms, and international trade" The Review of Economic Studies, 80(2), 711-744. 
McKenzie, D. (2010) “Impact Assessments in Finance and Private Sector Development: What have we learned and what should we learn?" The World Bank Research Observer, 25 (2): 209-233.

Melitz, M. J. (2003) "The impact of trade on intra - industry reallocations and aggregate industry productivity" Econometrica, 71(6), 1695-1725.

Melitz, M. J. and Ottaviano, G. I. (2008) "Market size, trade, and productivity" The Review of Economic Studies, 75(1), 295-316.

Olley, G. S., and A. Pakes (1996) "The dynamics of productivity in the telecommunications equipment industry." Econometrica 64: 1263-1297

Ottaviano, G. and Lage de Sousa, F. (2008) “O efeito do BNDES na Produtividade das Empresas" in Políticas de Incentivo à Inovação Tecnológica edited by De Negri, J. and Kubota, L., IPEA, Brasília.

Reikard, G. (2011) "Total factor productivity and R\&D in the production function" International Journal of Innovation and Technology Management, 8(04), 601-613.

Solow, R. M. (1957) "Technical change and the aggregate production function” Review of Economics and Statistics, 312-320.

Terra, M. C. (2003) "Credit constraints in Brazilian firms: evidence from panel data" Revista Brasileira de Economia, Vol. 57 (02), 443-464.

World Bank (2013) “The World Bank Annual Report 2013” Washington, DC. 


\section{Appendix I: List of Variables}

\begin{tabular}{|c|c|c|}
\hline \multicolumn{3}{|c|}{ Table A.1: Description of Variables } \\
\hline Variables & Variable Description & Source \\
\hline Multinationals & Number of Multinationals & BACEN \\
\hline$\%$ Multinationals & Share of Multinationals & BACEN \\
\hline Labor Productivity & Value Added / Number of Employees & PIA \\
\hline Value Added & Value Added & PIA \\
\hline Number of Employees & Number of Employees & PIA \\
\hline Average Wage & Total Wages / Number of Employees & PIA \\
\hline Investment & Total Investment & PIA \\
\hline Capital Stock & Capital Stock calculated by Perpetual Inventory (using Energy Consumption) & PIA \\
\hline Total Revenue & Total Revenue (including Financial Revenue, for example) & PIA \\
\hline Selling Revenue & Net Selling Revenues (only Goods) & PIA \\
\hline Market Share & Market Share by Net Selling Revenues & PIA \\
\hline Total Production Value & Value of Total Production (before taxes) & PIA \\
\hline Energy Consumption & Expenditure in Electricity and Fuel Expenditure & PIA \\
\hline Profitability & Net Profits / Total Revenue & PIA \\
\hline Net Profit & Net Profits & PIA \\
\hline Cash Flow & Net Profits plus Depreciation \& Amortizations & PIA \\
\hline Financial Status & Financial Expenditure / Total Costs & PIA \\
\hline Solvency & Financial Expenditure / Net Selling Revenue & PIA \\
\hline Financial Expenditures & Financial Expenditure & PIA \\
\hline Total Cost & Total Cost & PIA \\
\hline Efficiency & Production Cost / Total Production Value & PIA \\
\hline Tax 1 & Production Taxes / Selling Gross Revenue & PIA \\
\hline $\operatorname{Tax} 2$ & All Taxes (Production + Land) / Selling Gross Revenue & PIA \\
\hline Employees Growth & Annual Growth of Total Number of Employees & PIA \\
\hline Revenue Growth & Annual Growth of Net Selling Revenue & PIA \\
\hline Productivity Growth & Annual Growth of Productivity & PIA \\
\hline $\begin{array}{l}\text { Profit Growth } \\
\text { Number Firms }\end{array}$ & Annual Growth of Profits & PIA \\
\hline Profitable & Number of Firms which have earn Profits & PIA \\
\hline Share of Profitable & Share of Profitable Firms & PIA \\
\hline Rich Region & Number of Firms in Rich Regions & PIA \\
\hline \% Rich Region & Share of Firms in Rich Regions & PIA \\
\hline Small Size & Number of Firms which Number of Employees is less than 100 & PIA \\
\hline Medium Size & Number of Firms which Number of Employees is greater than 100 and less than 500 & PIA \\
\hline Large Size & Number of Firms which Number of Employees is greater than 500 & PIA \\
\hline Share of Small & Share of Small Firms $(<100)$ & PIA \\
\hline Share of Medium & Share of Medium Firms $(>100$ e $<500)$ & PIA \\
\hline Share of Large & Share of Large Firms $(>500)$ & PIA \\
\hline OCDE Classification & High, Medium-High, Medium-Low and Low Technology & PIA \& OCDE \\
\hline Export Coefficient & Total Exports / Total Production Value & PIA \& SECEX \\
\hline Import Coefficient & Total Imports / Total Production Value & PIA \& SECEX \\
\hline Input Imports Coef & Intermediates Goods Imports / Manufacturing Operation Cost & PIA \& SECEX \\
\hline Capital Imports Coef & Capital Goods Imports / Investments & PIA \& SECEX \\
\hline Age & Number of Years of Firm's existence & RAIS \\
\hline Workers' Schooling & Number of Years Spent on Education & RAIS \\
\hline Skill Worker \% & Share of Workers with at least Undergraduated Level Completed & RAIS \\
\hline Capital Imports & Capital Goods Imports & SECEX \\
\hline Input Imports & Intermediates Goods Imports & SECEX \\
\hline Total Exports & Total Volume of Exports FOB & SECEX \\
\hline Export Status & Percentage of Firms wich have exported during 1996 and 2006 & SECEX \\
\hline Total Imports & Total Volume of Imports FOB & SECEX \\
\hline
\end{tabular}




\section{Appendix II: Descriptive Statistics}

\begin{tabular}{|c|c|c|c|c|c|c|c|}
\hline \multirow{2}{*}{$\begin{array}{l}\text { Firms' Type } \\
\text { Variables }\end{array}$} & \multicolumn{3}{|c|}{ Non Treated Firms } & \multicolumn{3}{|c|}{ Treated Firms } & \multirow[b]{2}{*}{ Unit } \\
\hline & $\begin{array}{l}\text { All Firms over } 30 \\
\text { employees }\end{array}$ & $\begin{array}{c}\text { Survived and } \\
\text { Invested from } 1996 \\
\text { to } 2006\end{array}$ & $\begin{array}{l}\text { First Treated in } \\
2007\end{array}$ & $\begin{array}{c}\text { All First Time in } \\
1998\end{array}$ & $\begin{array}{l}\text { Automatic BNDES } \\
\text { First Time in } 1998\end{array}$ & All only in 1998 & \\
\hline Number of Firms & 21,380 & 6,344 & 128 & 141 & 112 & 75 & \\
\hline Age & 20.1 & 22.6 & 22.1 & 26.6 & 25.0 & 24.4 & Years \\
\hline Labor Productivity & 26.6 & 26.8 & 27.0 & 35.5 & 29.7 & 31.8 & $\mathrm{R} \$$ thousand / worker \\
\hline TFP Levinhson-Petrin & 100 & 101 & 93 & 115 & 107 & 106 & TFP All Firms $=100$ \\
\hline TFP Growth & $-3.2 \%$ & $-1.1 \%$ & $-2.9 \%$ & $0.5 \%$ & $-1.6 \%$ & $0.0 \%$ & $\%$ \\
\hline Investment / Capital & $3.7 \%$ & $4.0 \%$ & $4.2 \%$ & $6.6 \%$ & $6.9 \%$ & $5.5 \%$ & $\%$ \\
\hline Cash Flow / Capital & $12.3 \%$ & $16.7 \%$ & $19.0 \%$ & $10.5 \%$ & $10.4 \%$ & $11.2 \%$ & $\%$ \\
\hline Export Status & $32.2 \%$ & $40.0 \%$ & $38.3 \%$ & $58.9 \%$ & $54.5 \%$ & $49.3 \%$ & $\%$ \\
\hline Value Added & 6.84 & 7.40 & 12.07 & 28.90 & 9.99 & 24.95 & $\mathrm{R} \$$ millions \\
\hline Number of Employees & 175 & 196 & 255 & 620 & 332 & 468 & Number \\
\hline Workers' Schooling & 6.7 & 6.7 & 6.5 & 7.1 & 7.0 & 6.9 & Years \\
\hline Skilled Worker \% & $5.8 \%$ & $6.8 \%$ & $5.7 \%$ & $9.2 \%$ & $8.1 \%$ & $9.2 \%$ & $\%$ \\
\hline Investment & 1.17 & 0.86 & 1.24 & 5.45 & 1.58 & 4.79 & $\mathrm{R} \$$ millions \\
\hline Capital Stock 1 & 31.58 & 19.61 & 34.86 & 84.45 & 29.02 & 53.87 & $\mathrm{R} \$$ millions \\
\hline Capital Stock 2 & 32.35 & 18.15 & 32.19 & 113.44 & 33.22 & 81.44 & $\mathrm{R} \$$ millions \\
\hline Total Revenue & 17.01 & 16.56 & 25.21 & 80.71 & 22.66 & 82.02 & $\mathrm{R} \$$ millions \\
\hline Selling Revenue & 15.71 & 15.41 & 21.65 & 72.91 & 21.22 & 73.50 & $\mathrm{R} \$$ millions \\
\hline Market Share & $0.09 \%$ & $0.11 \%$ & $0.12 \%$ & $0.33 \%$ & $0.11 \%$ & $0.31 \%$ & $\%$ \\
\hline Total Production Value & 14.96 & 14.90 & 21.60 & 68.49 & 20.86 & 64.88 & $\mathrm{R} \$$ millions \\
\hline Capital Imports & 0.32 & 0.30 & 0.30 & 3.49 & 0.28 & 5.64 & $\mathrm{R} \$$ billions \\
\hline Input Imports & 1.18 & 1.20 & 1.54 & 3.97 & 0.63 & 4.20 & $\mathrm{R} \$$ billions \\
\hline Energy Consumption & 1.00 & 0.99 & 1.23 & 5.99 & 0.93 & 2.54 & $\mathrm{R} \$$ millions \\
\hline Profitability & $5.85 \%$ & $6.69 \%$ & $7.92 \%$ & $5.68 \%$ & $5.89 \%$ & $6.38 \%$ & $\%$ \\
\hline Solvency 1 & $3.9 \%$ & $3.0 \%$ & $2.2 \%$ & $2.8 \%$ & $2.8 \%$ & $3.1 \%$ & $\%$ \\
\hline Solvency 2 & $3.6 \%$ & $2.8 \%$ & $1.9 \%$ & $2.5 \%$ & $2.6 \%$ & $2.8 \%$ & $\%$ \\
\hline Financial Expenditures & 0.62 & 0.46 & 0.47 & 2.05 & 0.59 & 2.28 & $\mathrm{R} \$$ millions \\
\hline Total Cost & 18.2 & 16.6 & 24.4 & 79.3 & 22.1 & 80.2 & $\mathrm{R} \$$ millions \\
\hline Efficiency & $52 \%$ & $50 \%$ & $53 \%$ & $52 \%$ & $52 \%$ & $51 \%$ & $\%$ \\
\hline Tax 1 & $17 \%$ & $16 \%$ & $16 \%$ & $15 \%$ & $15 \%$ & $15 \%$ & $\%$ \\
\hline $\operatorname{Tax} 2$ & $17 \%$ & $16 \%$ & $17 \%$ & $15 \%$ & $15 \%$ & $15 \%$ & $\%$ \\
\hline Total Exports & 1.87 & 1.75 & 4.47 & 9.27 & 1.13 & 6.45 & $\mathrm{R} \$$ millions \\
\hline Total Imports & 1.75 & 1.78 & 2.14 & 8.67 & 1.20 & 11.68 & $\mathrm{R} \$$ millions \\
\hline Export Coefficient & $4.9 \%$ & $6.1 \%$ & $7.7 \%$ & $6.5 \%$ & $5.6 \%$ & $5.1 \%$ & $\%$ \\
\hline Import Coefficient & $4.2 \%$ & $4.6 \%$ & $5.3 \%$ & $5.6 \%$ & $4.6 \%$ & $4.5 \%$ & $\%$ \\
\hline Input Imports Coefficient & $4 \%$ & $5 \%$ & $7 \%$ & $6 \%$ & $5 \%$ & $5 \%$ & $\%$ \\
\hline Capital Imports Coefficient & $5 \%$ & $6 \%$ & $8 \%$ & $9 \%$ & $9 \%$ & $5 \%$ & $\%$ \\
\hline Employees Growth & $0.1 \%$ & $4.3 \%$ & $1.8 \%$ & $8.8 \%$ & $10.3 \%$ & $6.2 \%$ & $\%$ \\
\hline Revenue Growth & $22.1 \%$ & $20.6 \%$ & $16.9 \%$ & $17.5 \%$ & $13.7 \%$ & $13.8 \%$ & $\%$ \\
\hline Profit Growth & $45.8 \%$ & $50.1 \%$ & $15.3 \%$ & $44.4 \%$ & $50.3 \%$ & $65.1 \%$ & $\%$ \\
\hline Number Firms Profitable & 4,344 & 1,740 & 36 & 40 & 34 & 24 & Number \\
\hline Share of Profitable & $20.3 \%$ & $27.4 \%$ & $28.1 \%$ & $28.4 \%$ & $30.4 \%$ & $32.0 \%$ & $\%$ \\
\hline Multinationals & 1,089 & 509 & 7 & 21 & 13 & 8 & Number \\
\hline$\%$ Multinationals & $5.09 \%$ & $8.02 \%$ & $5.47 \%$ & $14.89 \%$ & $11.61 \%$ & $10.67 \%$ & $\%$ \\
\hline Rich Region & 18,165 & 5,505 & 119 & 124 & 97 & 61 & Number \\
\hline \% Rich Region & $85 \%$ & $87 \%$ & $93 \%$ & $88 \%$ & $87 \%$ & $81 \%$ & $\%$ \\
\hline Small Size & 14,416 & 3,584 & 69 & 43 & 42 & 31 & Number \\
\hline Medium Size & 5,686 & 2,304 & 45 & 57 & 48 & 27 & Number \\
\hline Large Size & 1,278 & 456 & 14 & 41 & 22 & 17 & Number \\
\hline Share of Small & $67 \%$ & $56 \%$ & $54 \%$ & $30 \%$ & $38 \%$ & $41 \%$ & $\%$ \\
\hline Share of Medium & $27 \%$ & $36 \%$ & $35 \%$ & $40 \%$ & $43 \%$ & $36 \%$ & $\%$ \\
\hline Share of Large & $6 \%$ & $7 \%$ & $11 \%$ & $29 \%$ & $20 \%$ & $23 \%$ & $\%$ \\
\hline
\end{tabular}




\begin{tabular}{|c|c|c|c|c|c|c|c|}
\hline \multicolumn{8}{|l|}{ OCDE Classification } \\
\hline High \& Medium-High Tech & 4,732 & 1,648 & 23 & 45 & 36 & 26 & Number \\
\hline Medium-Low Tech & 5,360 & 1,789 & 36 & 30 & 18 & 13 & Number \\
\hline Low Tech & 11,288 & 2,907 & 69 & 66 & 58 & 36 & Number \\
\hline Share High \& Medium-High Tech & $22 \%$ & $26 \%$ & $18 \%$ & $32 \%$ & $32 \%$ & $35 \%$ & $\%$ \\
\hline Share Medium-Low Tech & $25 \%$ & $28 \%$ & $28 \%$ & $21 \%$ & $16 \%$ & $17 \%$ & $\%$ \\
\hline Share Low Tech & $53 \%$ & $46 \%$ & $54 \%$ & $47 \%$ & $52 \%$ & $48 \%$ & $\%$ \\
\hline
\end{tabular}




\section{Appendix III: Propensity score matching}

\begin{tabular}{l|cc|cc|cc}
\hline \multicolumn{5}{c}{ Table A.3.a: Comparing Group 5 } & after Matching with Non Granted \\
\hline & \multicolumn{2}{c}{ Non-Treated } & \multicolumn{2}{c}{ Treated } & \multicolumn{2}{c}{ Testing Matched Firms } \\
& Not Matched & Matched & Matched & Not Matched & t Value & P-value \\
\hline Capital Stock & 18 & 26 & 30 & 20 & -0.49 & $62.8 \%$ \\
Number of Employees & 192 & 312 & 337 & 297 & -0.36 & $72.1 \%$ \\
Solvency & $3.0 \%$ & $2.4 \%$ & $2.6 \%$ & $4.3 \%$ & -0.39 & $69.8 \%$ \\
Profit & $6.7 \%$ & $6.1 \%$ & $6.5 \%$ & $1.0 \%$ & -0.40 & $68.6 \%$ \\
Profit Growth & $49 \%$ & $87 \%$ & $51 \%$ & $-23 \%$ & 1.22 & $22.5 \%$ \\
Employment Growth & $4 \%$ & $4 \%$ & $9 \%$ & $19 \%$ & -1.21 & $22.9 \%$ \\
Revenue Growth & $21 \%$ & $18 \%$ & $16 \%$ & $0 \%$ & 0.51 & $61.0 \%$ \\
Market Share & $0.10 \%$ & $0.10 \%$ & $0.10 \%$ & $0.00 \%$ & -1.43 & $15.3 \%$ \\
Multinational Status & $8 \%$ & $6 \%$ & $13 \%$ & $0 \%$ & -1.69 & $9.2 \%$ \\
Rich & $87 \%$ & $85 \%$ & $88 \%$ & $77 \%$ & -0.62 & $53.7 \%$ \\
Labor Productivity & 26.7 & 25.2 & 31.7 & 14.1 & -1.72 & $8.7 \%$ \\
TFP Productivity & 99.6 & 100 & 102.7 & 93.5 & -1.55 & $12.3 \%$ \\
Investment & 0.8 & 1.4 & 1.6 & 1.6 & -0.25 & $80.5 \%$ \\
Cash Flow / Capital & $16.8 \%$ & $10.8 \%$ & $10.1 \%$ & $12.4 \%$ & 0.41 & $68.2 \%$ \\
Investment / Capital & $4.0 \%$ & $4.4 \%$ & $7.0 \%$ & $6.4 \%$ & -2.94 & $0.3 \%$ \\
\hline Number of Firms & 6235 & 99 & 99 & 13 & & \\
\hline
\end{tabular}

\begin{tabular}{l|cc|cc|cc}
\hline \multicolumn{7}{c}{ Table A.3.b: Comparing Group 3 } \\
& \multicolumn{2}{c}{ Non-Treated Matching with Non Granted } \\
\hline & Not Matched & Matched & Matched & Noated & \multicolumn{2}{c}{ Testing Matched Firms } \\
t Value & P-value \\
\hline Capital Stock & 20 & 27 & 35 & 177 & -0.42 & $67.4 \%$ \\
Number of Employees & 195 & 298 & 302 & 1,553 & -0.05 & $95.8 \%$ \\
Solvency & $3.0 \%$ & $2.5 \%$ & $3.1 \%$ & $2.8 \%$ & 1.42 & $15.9 \%$ \\
Profit & $6.7 \%$ & $6.8 \%$ & $7.0 \%$ & $2.4 \%$ & -0.10 & $92.2 \%$ \\
Profit Growth & $50 \%$ & $54 \%$ & $63 \%$ & $117 \%$ & -0.27 & $79.1 \%$ \\
Employment Growth & $4 \%$ & $3 \%$ & $5 \%$ & $18 \%$ & -0.33 & $74.4 \%$ \\
Revenue Growth & $21 \%$ & $19 \%$ & $15 \%$ & $9 \%$ & 0.81 & $41.9 \%$ \\
Market Share & $0.1 \%$ & $0.1 \%$ & $0.1 \%$ & $1.6 \%$ & -0.65 & $51.4 \%$ \\
Multinational Status & $8 \%$ & $6 \%$ & $9 \%$ & $20 \%$ & -0.65 & $51.4 \%$ \\
Rich & $87 \%$ & $85 \%$ & $83 \%$ & $70 \%$ & 0.24 & $81.3 \%$ \\
Labor Productivity & 26.9 & 25.7 & 31.5 & 33.7 & -1.12 & $26.7 \%$ \\
TFP Productivity & 99.6 & 100.2 & 102.2 & 99.1 & -1.36 & $17.5 \%$ \\
Investment & 0.9 & 0.6 & 2.5 & 18.0 & -1.78 & $7.8 \%$ \\
Cash Flow / Capital & $16.7 \%$ & $10.5 \%$ & $10.3 \%$ & $17 \%$ & 0.08 & $93.6 \%$ \\
Investment / Capital & $4.0 \%$ & $5.9 \%$ & $4.1 \%$ & $14.4 \%$ & 1.59 & $11.2 \%$ \\
\hline Number of Firms & 6279 & 65 & 65 & 10 & & \\
\hline
\end{tabular}


Table A.3.c: Comparing Group 2 after Matching with Non Granted

\begin{tabular}{l|cc|cc|cc}
\hline & \multicolumn{2}{|c|}{ Non-Treated } & \multicolumn{2}{c|}{ Treated } & \multicolumn{2}{c}{ Testing Matched Firms } \\
& Not Matched & Matched & Matched & Not Matched & t Value & P-value \\
\hline Capital Stock & 12 & 48 & 74 & 43 & -0.98 & $33.0 \%$ \\
Number of Employees & 131 & 384 & 561 & 464 & -1.61 & $10.8 \%$ \\
Solvency & $3.9 \%$ & $2.5 \%$ & $2.6 \%$ & $3.2 \%$ & -0.27 & $78.6 \%$ \\
Profit & $6.0 \%$ & $5.4 \%$ & $6.2 \%$ & $4.4 \%$ & -0.91 & $36.3 \%$ \\
Profit Growth & $55 \%$ & $4 \%$ & $1 \%$ & $32 \%$ & 1.45 & $15.1 \%$ \\
Employment Growth & $-1 \%$ & $12 \%$ & $9 \%$ & $10 \%$ & 0.55 & $58.0 \%$ \\
Revenue Growth & $20 \%$ & $102 \%$ & $18 \%$ & $14 \%$ & 1.13 & $26.1 \%$ \\
Market Share & $0.1 \%$ & $0.2 \%$ & $0.3 \%$ & $0.4 \%$ & -1.19 & $23.6 \%$ \\
Multinational Status & $5 \%$ & $10 \%$ & $14 \%$ & $10 \%$ & -1.01 & $31.4 \%$ \\
Rich & $84 \%$ & $89 \%$ & $90 \%$ & $79 \%$ & -0.18 & $85.9 \%$ \\
Labor Productivity & 67.2 & 136.7 & 101.6 & 97.9 & 1.09 & $27.6 \%$ \\
TFP Productivity & 100.2 & 83.4 & 80.5 & 88.7 & 0.87 & $38.6 \%$ \\
Investment & 1.7 & 17.2 & 14.4 & 10.4 & 0.21 & $83.2 \%$ \\
\hline Number of Firms & 18,240 & 169 & 169 & 58 & & \\
\hline
\end{tabular}

Results on Cash Flow/Investment and Investment/Capital show similar patterns and are available upon request. 
Table A.3.d: Comparing Group 4 after Matching with Non Granted

\begin{tabular}{l|cc|cc|cc}
\hline & \multicolumn{2}{|c|}{ Non-Treated } & \multicolumn{2}{c|}{ Treated } & \multicolumn{2}{c}{ Testing Matched Firms } \\
& Not Matched & Matched & Matched & Not Matched & t Value & P-value \\
\hline Capital Stock & 12 & 18 & 51 & 31 & -2.07 & $4.1 \%$ \\
Number of Employees & 133 & 263 & 438 & 380 & -1.48 & $14.1 \%$ \\
Solvency & $3.9 \%$ & $2.6 \%$ & $2.9 \%$ & $3.4 \%$ & -0.57 & $56.9 \%$ \\
Profit & $6.0 \%$ & $5.0 \%$ & $6.8 \%$ & $4.4 \%$ & -1.63 & $10.4 \%$ \\
Profit Growth & $55 \%$ & $5 \%$ & $1 \%$ & $-1 \%$ & 1.32 & $19.3 \%$ \\
Employment Growth & $-1 \%$ & $7 \%$ & $7 \%$ & $17 \%$ & 0.04 & $96.8 \%$ \\
Revenue Growth & $21 \%$ & $32 \%$ & $16 \%$ & $16 \%$ & 1.53 & $12.8 \%$ \\
Market Share & $0.1 \%$ & $0.1 \%$ & $0.2 \%$ & $0.4 \%$ & -1.40 & $16.5 \%$ \\
Multinational Status & $5 \%$ & $10 \%$ & $14 \%$ & $10 \%$ & 0.23 & $81.9 \%$ \\
Rich & $84 \%$ & $90 \%$ & $87 \%$ & $77 \%$ & 0.64 & $52.6 \%$ \\
Labor Productivity & 67.7 & 91.5 & 83.5 & 86.3 & 0.51 & $60.8 \%$ \\
TFP Productivity & 100.1 & 86.9 & 83.6 & 99.1 & 0.85 & $39.4 \%$ \\
Investment & 1.9 & 2.6 & 12.8 & 6.7 & -1.85 & $6.7 \%$ \\
\hline Number of Firms & 18.301 & 108 & 108 & 35 & & \\
\hline
\end{tabular}

Results on Cash Flow/Investment and Investment/Capital show similar patterns and are available upon request.

Table A.3.e: Comparing Group 6 after Matching with Non Granted

\begin{tabular}{|c|c|c|c|c|c|c|}
\hline & \multicolumn{2}{|c|}{ Non-Treated } & \multicolumn{2}{|c|}{ Treated } & \multicolumn{2}{|c|}{ Testing Matched Firms } \\
\hline & Not Matched & Matched & Matched & Not Matched & t Value & P-value \\
\hline Capital Stock & 12 & 22 & 30 & 16 & -1.21 & $22.6 \%$ \\
\hline Number of Employees & 131 & 286 & 333 & 251 & -0.84 & $40.1 \%$ \\
\hline Solvency & $3.9 \%$ & $2.4 \%$ & $2.5 \%$ & $3.6 \%$ & -0.19 & $85.0 \%$ \\
\hline Profit & $6.0 \%$ & $5.2 \%$ & $6.4 \%$ & $4.8 \%$ & -1.36 & $17.4 \%$ \\
\hline Profit Growth & $55 \%$ & $5 \%$ & $1 \%$ & $45 \%$ & 1.56 & $12.4 \%$ \\
\hline Employment Growth & $-1 \%$ & $11 \%$ & $9 \%$ & $15 \%$ & 0.21 & $83.4 \%$ \\
\hline Revenue Growth & $20 \%$ & $112 \%$ & $16 \%$ & $13 \%$ & 1.11 & $27.0 \%$ \\
\hline Market Share & $0.1 \%$ & $0.1 \%$ & $0.1 \%$ & $0.1 \%$ & -0.67 & $50.3 \%$ \\
\hline Multinational Status & $5 \%$ & $8 \%$ & $10 \%$ & $9 \%$ & -0.60 & $54.6 \%$ \\
\hline Rich & $84 \%$ & $91 \%$ & $90 \%$ & $80 \%$ & 0.40 & $69.2 \%$ \\
\hline Labor Productivity & 67.5 & 88.1 & 88.0 & 70.6 & 0.01 & $98.9 \%$ \\
\hline TFP Productivity & 100.1 & 86.4 & 86.2 & 97.7 & 0.06 & $95.0 \%$ \\
\hline Investment & 1.8 & 3.8 & 4.1 & 3.9 & -0.24 & $81.0 \%$ \\
\hline Number of Firms & 18.237 & 144 & 144 & 46 & & \\
\hline
\end{tabular}

Results on Cash Flow/Investment and Investment/Capital show similar patterns and are available upon request. 


\section{Appendix IV: Credit constraints for alternative treated groups}

Table A.4.a: Credit Restriction for Group 3

\begin{tabular}{lcccc}
\hline Dependent Variable: Invest / K & Group A & Group B & Group C & Paired Firms \\
& $(1)$ & $(2)$ & $(3)$ & $(4)$ \\
\hline Cash Flow / K & $0.000827^{\star \star *}$ & 0.000519 & 0.0141 & 0.0871 \\
& $(0.00041)$ & $(0.00109)$ & $(0.0159)$ & $(0.0656)$ \\
BNDES * Cash Flow / K & 0.0599 & 0.0549 & 0.0544 & 0.0836 \\
& $(0.0373)$ & $(0.0370)$ & $(0.0452)$ & $(0.0686)$ \\
Sales / K & $-0.00029^{\star * *}$ & $-0.000423^{* * *}$ & $-0.00131^{* *}$ & $-0.0417^{\star * *}$ \\
& $(3.45 e-05)$ & $(0.000158)$ & $(0.00558)$ & $(0.00978)$ \\
Sales / K lagged in time & $0.000352^{\star \star *}$ & $0.000290^{\star * *}$ & $0.000952^{\star * *}$ & $0.0344^{\star * *}$ \\
& $(1.95 e-05)$ & $(2.43 e-05)$ & $(0.000258)$ & $(0.00673)$ \\
OCDE Tech. Dummy & Yes & Yes & Yes & Yes \\
Region Dummy & Yes & Yes & Yes & Yes \\
Multinational Dummy & Yes & Yes & Yes & Yes \\
Size Dummy & Yes & Yes & Yes & Yes \\
\hline Observations & 18.038 & 6.419 & 203 & 128 \\
R-squared & 0.110 & 0.129 & 0.246 & 0.324 \\
\hline
\end{tabular}

Standard errors in parentheses

*** $p<0.01,{ }^{* \star} p<0.05,{ }^{*} p<0.1$

Table A.4.b: Credit Restriction for Group 5

\begin{tabular}{|c|c|c|c|c|}
\hline Dependent Variable: Invest / K & $\begin{array}{c}\text { Group A } \\
(1)\end{array}$ & $\begin{array}{c}\text { Group B } \\
(2)\end{array}$ & $\begin{array}{c}\text { Group C } \\
(3)\end{array}$ & $\begin{array}{c}\text { Paired Firms } \\
(4)\end{array}$ \\
\hline \multirow[t]{2}{*}{ Cash Flow / K } & $0.000814^{\star \star \star}$ & 0.000430 & -0.00642 & 0.0664 \\
\hline & $(0.000411)$ & $(0.00110)$ & $(0.0167)$ & $(0.0426)$ \\
\hline \multirow[t]{2}{*}{ BNDES * Cash Flow / K } & $0.135^{\star \star \star}$ & $0.126^{\star \star \star}$ & $0.114^{\star \star}$ & 0.0728 \\
\hline & (0.0349) & $(0.0346)$ & $(0.0485)$ & $(0.0646)$ \\
\hline \multirow[t]{2}{*}{ Sales / K } & $-0.00029 * \star \star$ & $-0.000414^{\star * *}$ & -0.00106 & $-0.0524^{\star \star \star}$ \\
\hline & $(3.46 e-05)$ & $(0.000159)$ & $(0.00404)$ & $(0.0113)$ \\
\hline \multirow[t]{2}{*}{ Sales / K lagged in time } & $0.000352^{\star \star \star}$ & $0.000290 * * *$ & $0.000501^{* * *}$ & $0.0299 * \star *$ \\
\hline & $(1.96 e-05)$ & $(2.44 \mathrm{e}-05)$ & $(0.000208)$ & $(0.00587)$ \\
\hline OCDE Tech. Dummy & Yes & Yes & Yes & Yes \\
\hline Region Dummy & Yes & Yes & Yes & Yes \\
\hline Multinational Dummy & Yes & Yes & Yes & Yes \\
\hline Size Dummy & Yes & Yes & Yes & Yes \\
\hline Observations & 18.075 & 6.456 & 240 & 180 \\
\hline R-squared & 0.111 & 0.131 & 0.207 & 0.222 \\
\hline
\end{tabular}

Standard errors in parentheses

*** $p<0.01$, ** $p<0.05,{ }^{*} p<0.1$ 


\section{Appendix V: Post-treatment performance for alternative treated groups}

\begin{tabular}{|c|c|c|c|c|c|c|c|c|}
\hline \multicolumn{9}{|c|}{ Table A.5.a: Results of Difference-in-Differences (More than Once) } \\
\hline \multirow{3}{*}{$\begin{array}{l}\text { Treated Group } \\
\text { Control Group } \\
\text { Dependent Variable }\end{array}$} & \multicolumn{4}{|c|}{ Group 1} & \multicolumn{4}{|c|}{ Group 2} \\
\hline & \multicolumn{2}{|c|}{ Group A } & \multicolumn{2}{|c|}{ Paired } & \multicolumn{2}{|c|}{ Group A } & \multicolumn{2}{|c|}{ Paired } \\
\hline & Labor & TFP & Labor & TFP & Labor & TFP & Labor & TFP \\
\hline Effect in 1998 & $\begin{array}{l}0.130^{\star *} \\
(0.0577)\end{array}$ & $\begin{array}{c}0.00176 \\
(0.00870)\end{array}$ & $\begin{array}{c}0.103 \\
(0.102)\end{array}$ & $\begin{array}{c}0.00371 \\
(0.00319)\end{array}$ & $\begin{array}{c}0.0562 \\
(0.0625)\end{array}$ & $\begin{array}{c}0.00904 \\
(0.00845)\end{array}$ & $\begin{array}{c}0.0531 \\
(0.0951)\end{array}$ & $\begin{array}{l}-0.000451 \\
(0.00176)\end{array}$ \\
\hline Effect in 1999 & $\begin{array}{l}0.150 * * * \\
(0.0549)\end{array}$ & $\begin{array}{l}-0.00273 \\
(0.00916)\end{array}$ & $\begin{array}{c}0.0940 \\
(0.0983)\end{array}$ & $\begin{array}{c}0.00188 \\
(0.00291)\end{array}$ & $\begin{array}{c}0.0922 \\
(0.0573)\end{array}$ & $\begin{array}{c}0.00208 \\
(0.00993)\end{array}$ & $\begin{array}{l}0.0838 \\
(0.129)\end{array}$ & $\begin{array}{l}-0.00264 \\
(0.00181)\end{array}$ \\
\hline Effect in 2000 & $\begin{array}{l}0.181^{\star \star *} \\
(0.0562)\end{array}$ & $\begin{array}{l}-0.0853 \\
(0.0714)\end{array}$ & $\begin{array}{c}0.194 \\
(0.118)\end{array}$ & $\begin{array}{c}0.00112 \\
(0.00286)\end{array}$ & $\begin{array}{c}0.124^{\star} \\
(0.0665)\end{array}$ & $\begin{array}{l}-0.0829 \\
(0.0700)\end{array}$ & $\begin{array}{l}0.0589 \\
(0.122)\end{array}$ & $\begin{array}{l}-0.00167 \\
(0.00115)\end{array}$ \\
\hline Effect in 2001 & $\begin{array}{l}0.163^{\star \star *} \\
(0.0589)\end{array}$ & $\begin{array}{l}-0.0115 \\
(0.0109)\end{array}$ & $\begin{array}{l}0.195^{\star} \\
(0.119)\end{array}$ & $\begin{array}{c}0.00101 \\
(0.00278)\end{array}$ & $\begin{array}{l}0.137^{\star * *} \\
(0.0513)\end{array}$ & $\begin{array}{c}-0.00943 \\
(0.0108)\end{array}$ & $\begin{array}{c}-0.00842 \\
(0.0757)\end{array}$ & $\begin{array}{l}-0.00216^{*} \\
(0.00115)\end{array}$ \\
\hline Effect in 2002 & $\begin{array}{l}0.169 * \star * \\
(0.0567)\end{array}$ & $\begin{array}{l}-0.0165^{\star} \\
(0.00976)\end{array}$ & $\begin{array}{c}0.0724 \\
(0.0736)\end{array}$ & $\begin{array}{c}0.00245 \\
(0.00285)\end{array}$ & $\begin{array}{c}0.126^{* *} \\
(0.0495)\end{array}$ & $\begin{array}{c}-0.0136 \\
(0.00982)\end{array}$ & $\begin{array}{c}0.0906 \\
(0.0848)\end{array}$ & $\begin{array}{l}-0.00113 \\
(0.00126)\end{array}$ \\
\hline Effect in 2003 & $\begin{array}{c}0.126^{\star \star} \\
(0.0529)\end{array}$ & $\begin{array}{l}-0.0117 \\
(0.0103)\end{array}$ & $\begin{array}{c}0.104 \\
(0.0743)\end{array}$ & $\begin{array}{l}0.000838 \\
(0.00276)\end{array}$ & $\begin{array}{c}0.0703 \\
(0.0500)\end{array}$ & $\begin{array}{l}-0.00960 \\
(0.0114)\end{array}$ & $\begin{array}{c}0.0553 \\
(0.0865)\end{array}$ & $\begin{array}{l}-0.00198^{*} \\
(0.00113)\end{array}$ \\
\hline Effect in 2004 & $\begin{array}{l}0.0993^{*} \\
(0.0583)\end{array}$ & $\begin{array}{c}-0.0269 * \star \\
(0.0125)\end{array}$ & $\begin{array}{c}0.0918 \\
(0.0760)\end{array}$ & $\begin{array}{r}-0.000126 \\
(0.00309)\end{array}$ & $\begin{array}{c}0.0424 \\
(0.0537)\end{array}$ & $\begin{array}{c}-0.0259 * * \\
(0.0131)\end{array}$ & $\begin{array}{c}0.0638 \\
(0.0910)\end{array}$ & $\begin{array}{l}-0.00217^{*} \\
(0.00120)\end{array}$ \\
\hline Effect in 2005 & $\begin{array}{c}0.0573 \\
(0.0587)\end{array}$ & $\begin{array}{l}-0.0300^{\star} \\
(0.0164)\end{array}$ & $\begin{array}{c}0.0717 \\
(0.0763)\end{array}$ & $\begin{array}{l}-6.61 e-05 \\
(0.00307)\end{array}$ & $\begin{array}{c}0.0176 \\
(0.0515)\end{array}$ & $\begin{array}{l}-0.0289^{\star} \\
(0.0168)\end{array}$ & $\begin{array}{c}0.0282 \\
(0.0856)\end{array}$ & $\begin{array}{c}-0.00317^{\star *} \\
(0.00151)\end{array}$ \\
\hline Effect in 2006 & $\begin{array}{c}0.0122 \\
(0.0581)\end{array}$ & $\begin{array}{c}-0.0528^{\star * *} \\
(0.0174)\end{array}$ & $\begin{array}{c}0.0789 \\
(0.0744)\end{array}$ & $\begin{array}{l}0.000593 \\
(0.00276)\end{array}$ & $\begin{array}{l}-0.0216 \\
(0.0516)\end{array}$ & $\begin{array}{c}-0.0516^{\star * *} \\
(0.0179)\end{array}$ & $\begin{array}{l}-0.0242 \\
(0.0800)\end{array}$ & $\begin{array}{c}-0.00248^{\star *} \\
(0.00125)\end{array}$ \\
\hline Multiple Treatments & $\begin{array}{c}0.00255 \\
(0.00802)\end{array}$ & $\begin{array}{l}0.0129 * \star \star \\
(0.00403)\end{array}$ & $\begin{array}{c}0.0120 \\
(0.0102)\end{array}$ & $\begin{array}{c}0.000218 \\
(0.000148)\end{array}$ & $\begin{array}{c}0.0182^{\star \star} \\
(0.00882)\end{array}$ & $\begin{array}{l}0.0137^{\star \star *} \\
(0.00431)\end{array}$ & $\begin{array}{l}0.0315^{\star \star \star} \\
(0.00969)\end{array}$ & $\begin{array}{l}0.000259^{\star \star} \\
(0.000121)\end{array}$ \\
\hline Domestic Capital & $\begin{array}{l}0.0194^{\star * *} \\
(0.00450)\end{array}$ & & $\begin{array}{l}-0.0217 \\
(0.0301)\end{array}$ & & $\begin{array}{l}0.0190 \star \star \star \\
(0.00450)\end{array}$ & & $\begin{array}{l}-0.0156 \\
(0.0326)\end{array}$ & \\
\hline Imported Capital & $\begin{array}{c}0.0181^{\star \star} \\
(0.00904)\end{array}$ & & $\begin{array}{l}0.0529 * * \\
(0.0225)\end{array}$ & & $\begin{array}{c}0.0189^{\star \star} \\
(0.00906)\end{array}$ & & $\begin{array}{c}0.0357 \\
(0.0360)\end{array}$ & \\
\hline Imported Input & $\begin{array}{l}0.436^{\star \star \star} \\
(0.0966)\end{array}$ & $\begin{array}{c}0.0777^{\star \star \star} \\
(0.0224)\end{array}$ & $\begin{array}{l}0.710^{\star \star *} \\
(0.199)\end{array}$ & $\begin{array}{l}0.0224^{\star \star \star} \\
(0.00703)\end{array}$ & $\begin{array}{l}0.439 * \star \star \\
(0.0970)\end{array}$ & $\begin{array}{c}0.0774^{\star \star \star} \\
(0.0223)\end{array}$ & $\begin{array}{l}0.598^{\star \star} \\
(0.279)\end{array}$ & $\begin{array}{l}0.00476 * * \\
(0.00191)\end{array}$ \\
\hline Export Coefficient & $\begin{array}{l}0.203^{\star \star *} \\
(0.0384)\end{array}$ & $\begin{array}{l}0.00188 \\
(0.0133)\end{array}$ & $\begin{array}{c}0.118^{\star} \\
(0.0662)\end{array}$ & $\begin{array}{c}0.00408^{\star \star \star} \\
(0.00122)\end{array}$ & $\begin{array}{l}0.204^{\star \star \star} \\
(0.0386)\end{array}$ & $\begin{array}{l}0.00186 \\
(0.0133)\end{array}$ & $\begin{array}{c}0.0904 \\
(0.0691)\end{array}$ & $\begin{array}{l}0.00215^{\star \star} \\
(0.00104)\end{array}$ \\
\hline Import Coefficient & $\begin{array}{c}-1.211^{\star * \star} \\
(0.163)\end{array}$ & $\begin{array}{l}-0.115^{\star \star \star} \\
(0.0338)\end{array}$ & $\begin{array}{c}-1.156^{\star \star \star} \\
(0.331)\end{array}$ & $\begin{array}{l}-0.0341^{\star * \star} \\
(0.00793)\end{array}$ & $\begin{array}{c}-1.218^{\star \star *} \\
(0.164)\end{array}$ & $\begin{array}{l}-0.115^{\star * \star} \\
(0.0335)\end{array}$ & $\begin{array}{c}-1.426^{\star \star \star} \\
(0.520)\end{array}$ & $\begin{array}{c}-0.00890^{\star \star \star} \\
(0.00204)\end{array}$ \\
\hline Net Sales Revenue & $\begin{array}{c}0.496^{\star \star \star} \\
(0.00490)\end{array}$ & $\begin{array}{c}-0.0468^{\star \star *} \\
(0.00879)\end{array}$ & $\begin{array}{l}0.584^{\star \star *} \\
(0.0275)\end{array}$ & $\begin{array}{c}-0.00301^{\star * *} \\
(0.000410)\end{array}$ & $\begin{array}{c}0.496^{\star * *} \\
(0.00489)\end{array}$ & $\begin{array}{c}-0.0468^{\star \star *} \\
(0.00878)\end{array}$ & $\begin{array}{l}0.630^{\star * *} \\
(0.0289)\end{array}$ & $\begin{array}{c}-0.00249^{* * *} \\
(0.000279)\end{array}$ \\
\hline Number of Employees & $\begin{array}{l}-0.423^{\star * *} \\
(0.00666)\end{array}$ & & $\begin{array}{l}-0.582^{\star * \star} \\
(0.0395)\end{array}$ & & $\begin{array}{l}-0.423^{\star * \star} \\
(0.00665)\end{array}$ & & $\begin{array}{l}-0.560 * \star * \\
(0.0372)\end{array}$ & \\
\hline Cost / Revenue & $\begin{array}{l}-2.010^{\star \star \star} \\
(0.0750)\end{array}$ & $\begin{array}{l}-0.163^{\star \star \star} \\
(0.0433)\end{array}$ & $\begin{array}{c}-1.670^{* * *} \\
(0.378)\end{array}$ & $\begin{array}{l}-0.0158^{\star * *} \\
(0.00365)\end{array}$ & $\begin{array}{l}-2.009 * * * \\
(0.0748)\end{array}$ & $\begin{array}{l}-0.163^{\star \star *} \\
(0.0432)\end{array}$ & $\begin{array}{c}-1.554^{\star \star \star} \\
(0.237)\end{array}$ & $\begin{array}{c}-0.0158^{\star * *} \\
(0.00496)\end{array}$ \\
\hline Firms' Age & $\begin{array}{l}-0.0175^{\star \star \star} \\
(0.00380)\end{array}$ & $\begin{array}{c}-0.0817^{\star \star *} \\
(0.0283)\end{array}$ & $\begin{array}{l}0.0997^{*} \\
(0.0516)\end{array}$ & $\begin{array}{l}-0.000177 \\
(0.000829)\end{array}$ & $\begin{array}{l}-0.0174^{\star * \star} \\
(0.00380)\end{array}$ & $\begin{array}{c}-0.0815^{\star \star \star} \\
(0.0282)\end{array}$ & $\begin{array}{l}-0.106^{\star \star} \\
(0.0422)\end{array}$ & $\begin{array}{l}-0.00194 * \star * \\
(0.000484)\end{array}$ \\
\hline Years of Schooling & $\begin{array}{c}-0.0162^{\star} \\
(0.00971)\end{array}$ & $\begin{array}{l}-0.0195 \\
(0.0141)\end{array}$ & $\begin{array}{l}0.266^{\star \star} \\
(0.115)\end{array}$ & $\begin{array}{c}0.00244 \\
(0.00245)\end{array}$ & $\begin{array}{c}-0.0165^{\star} \\
(0.00970)\end{array}$ & $\begin{array}{l}-0.0195 \\
(0.0141)\end{array}$ & $\begin{array}{l}-0.0499 \\
(0.0594)\end{array}$ & $\begin{array}{l}0.000118 \\
(0.00112)\end{array}$ \\
\hline Skilled Labor & $\begin{array}{l}0.309 * \star * \\
(0.0350)\end{array}$ & $\begin{array}{c}0.0198 \\
(0.0436)\end{array}$ & $\begin{array}{l}-0.0225 \\
(0.195)\end{array}$ & $\begin{array}{l}-0.0104^{\star \star \star} \\
(0.00341)\end{array}$ & $\begin{array}{l}0.312^{\star \star \star} \\
(0.0349)\end{array}$ & $\begin{array}{c}0.0202 \\
(0.0437)\end{array}$ & $\begin{array}{c}0.517^{* * *} \\
(0.147)\end{array}$ & $\begin{array}{c}0.00170 \\
(0.00181)\end{array}$ \\
\hline Average Salary & $\begin{array}{c}0.567^{\star \star \star} \\
(0.00682)\end{array}$ & $\begin{array}{c}0.0534^{\star * *} \\
(0.0118)\end{array}$ & $\begin{array}{l}0.435^{\star \star \star} \\
(0.0351)\end{array}$ & $\begin{array}{c}0.000782 \\
(0.000930)\end{array}$ & $\begin{array}{c}0.566^{\star \star \star} \\
(0.00681)\end{array}$ & $\begin{array}{c}0.0534^{\star * *} \\
(0.0118)\end{array}$ & $\begin{array}{l}0.400 * * * \\
(0.0390)\end{array}$ & $\begin{array}{c}0.000586 \\
(0.000599)\end{array}$ \\
\hline Investment & $\begin{array}{c}0.0103^{\star \star \star} \\
(0.000421)\end{array}$ & $\begin{array}{l}-0.00394^{\star * *} \\
(0.000930)\end{array}$ & $\begin{array}{l}0.00989 * * \\
(0.00389)\end{array}$ & $\begin{array}{c}-0.000204^{\star * *} \\
(6.66 \mathrm{e}-05)\end{array}$ & $\begin{array}{c}0.0104^{\star \star \star} \\
(0.000421)\end{array}$ & $\begin{array}{l}-0.00393^{\star \star *} \\
(0.000927)\end{array}$ & $\begin{array}{l}0.0172^{\star \star \star} \\
(0.00329)\end{array}$ & $\begin{array}{c}-0.000149^{\star \star \star} \\
(4.33 \mathrm{e}-05)\end{array}$ \\
\hline Solvency & $\begin{array}{l}1.272^{\star \star \star} \\
(0.0856)\end{array}$ & $\begin{array}{c}0.0103 \\
(0.0273) \\
\end{array}$ & $\begin{array}{c}1.323^{\star \star \star} \\
(0.265)\end{array}$ & $\begin{array}{c}0.00349 \\
(0.00347) \\
\end{array}$ & $\begin{array}{l}1.270^{\star \star \star} \\
(0.0854)\end{array}$ & $\begin{array}{c}0.0103 \\
(0.0273) \\
\end{array}$ & $\begin{array}{l}1.734^{\star \star \star} \\
(0.327)\end{array}$ & $\begin{array}{c}0.00977 \\
(0.00827) \\
\end{array}$ \\
\hline
\end{tabular}




\begin{tabular}{|c|c|c|c|c|c|c|c|c|}
\hline & able A.5.a & esults of D & rence-in & erences (M & than Onc & - Continuat & & \\
\hline Revenue Growth & $\begin{array}{l}-0.461^{\star * *} \\
(0.0126)\end{array}$ & $\begin{array}{l}0.0176^{\star \star \star} \\
(0.00592)\end{array}$ & $\begin{array}{c}-0.373^{\star *} \\
(0.145)\end{array}$ & $\begin{array}{l}0.00294^{\star \star *} \\
(0.000706)\end{array}$ & $\begin{array}{l}-0.461^{\star * *} \\
(0.0126)\end{array}$ & $\begin{array}{l}0.0176^{\star * *} \\
(0.00590)\end{array}$ & $\begin{array}{c}-0.364^{\star * *} \\
(0.125)\end{array}$ & $\begin{array}{c}0.00160 * \\
(0.000832)\end{array}$ \\
\hline Employment Growth & $\begin{array}{l}0.463^{\star \star *} \\
(0.0117)\end{array}$ & $\begin{array}{c}0.0186 \\
(0.0223)\end{array}$ & $\begin{array}{c}0.478^{* * *} \\
(0.162)\end{array}$ & $\begin{array}{c}-0.000764 \\
(0.00142)\end{array}$ & $\begin{array}{l}0.463^{\star * \star} \\
(0.0117)\end{array}$ & $\begin{array}{c}0.0186 \\
(0.0222)\end{array}$ & $\begin{array}{c}0.460 * \star \star \\
(0.130)\end{array}$ & $\begin{array}{r}-0.000303 \\
(0.000666)\end{array}$ \\
\hline Productivity Growth & $\begin{array}{c}0.492^{\star \star \star} \\
(0.00995)\end{array}$ & $\begin{array}{c}0.000691 \\
(0.000564)\end{array}$ & $\begin{array}{c}0.483^{\star \star \star} \\
(0.168)\end{array}$ & $\begin{array}{c}9.54 \mathrm{e}-05 \\
(0.000134)\end{array}$ & $\begin{array}{c}0.492^{\star \star \star} \\
(0.00994)\end{array}$ & $\begin{array}{c}0.000676 \\
(0.000567)\end{array}$ & $\begin{array}{l}0.483^{\star \star \star} \\
(0.132)\end{array}$ & $\begin{array}{c}0.000305^{\star \star} \\
(0.000134)\end{array}$ \\
\hline Profitable & $\begin{array}{c}0.170 * \star \star \\
(0.00772)\end{array}$ & $\begin{array}{l}-0.00544 \\
(0.00948)\end{array}$ & $\begin{array}{l}0.00363 \\
(0.0251)\end{array}$ & $\begin{array}{l}-0.000476 \\
(0.000510)\end{array}$ & $\begin{array}{c}0.170 * \star \star \\
(0.00770)\end{array}$ & $\begin{array}{l}-0.00544 \\
(0.00945)\end{array}$ & $\begin{array}{c}0.0772^{\star \star \star} \\
(0.0231)\end{array}$ & $\begin{array}{l}-0.000454 \\
(0.000422)\end{array}$ \\
\hline Multinational Status & $\begin{array}{c}0.0506^{\star * *} \\
(0.0109)\end{array}$ & $\begin{array}{l}0.0120^{\star \star \star} \\
(0.00375)\end{array}$ & $\begin{array}{l}-0.0659 * \\
(0.0371)\end{array}$ & $\begin{array}{c}0.00181^{\star \star} \\
(0.000873)\end{array}$ & $\begin{array}{c}0.0492^{\star * *} \\
(0.0109)\end{array}$ & $\begin{array}{l}0.0115^{\star \star \star} \\
(0.00355)\end{array}$ & $\begin{array}{l}0.00730 \\
(0.0359)\end{array}$ & $\begin{array}{l}0.00130 * * * \\
(0.000416)\end{array}$ \\
\hline Year Dummy & Yes & Yes & Yes & Yes & Yes & Yes & Yes & Yes \\
\hline OCDE Dummy & Yes & Yes & Yes & Yes & Yes & Yes & Yes & Yes \\
\hline Size Dummy & Yes & Yes & Yes & Yes & Yes & Yes & Yes & Yes \\
\hline Sector Dummy & Yes & Yes & Yes & Yes & Yes & Yes & Yes & Yes \\
\hline Region Dummy & Yes & Yes & Yes & Yes & Yes & Yes & Yes & Yes \\
\hline Observations & 203.418 & 175.963 & 2.336 & 2.317 & 203.943 & 176.488 & 2.703 & 2.689 \\
\hline R-squared & 0.693 & 0.481 & 0.779 & 0.495 & 0.694 & 0.481 & 0.754 & 0.547 \\
\hline
\end{tabular}

Robust standard errors in parentheses

${ }^{* * \star} p<0.01,{ }^{* *} p<0.05,{ }^{*} p<0.1$ 


\begin{tabular}{|c|c|c|c|c|c|c|c|c|}
\hline \multicolumn{9}{|c|}{ Table A.5.b: Results of Difference-in-Differences (Just Once) } \\
\hline \multirow{3}{*}{$\begin{array}{l}\text { Treated Group } \\
\text { Control Group } \\
\text { Dependent Variable }\end{array}$} & \multicolumn{4}{|c|}{ Group 3} & \multicolumn{4}{|c|}{ Group 4} \\
\hline & \multicolumn{2}{|c|}{ Group A } & \multicolumn{2}{|c|}{ Paired } & \multicolumn{2}{|c|}{ Group A } & \multicolumn{2}{|c|}{ Paired } \\
\hline & Labor & TFP & Labor & TFP & Labor & TFP & Labor & TFP \\
\hline Effect in 1998 & $\begin{array}{c}0.0261 \\
(0.0822)\end{array}$ & $\begin{array}{c}0.0194^{\star *} \\
(0.00868)\end{array}$ & $\begin{array}{c}0.00939 \\
(0.104)\end{array}$ & $\begin{array}{l}-0.0165 \\
(0.0174)\end{array}$ & $\begin{array}{c}0.0493 \\
(0.0902)\end{array}$ & $\begin{array}{c}0.0119 \\
(0.0109)\end{array}$ & $\begin{array}{c}0.113 \\
(0.135)\end{array}$ & $\begin{array}{c}-0.000821 \\
(0.00237)\end{array}$ \\
\hline Effect in 1999 & $\begin{array}{c}0.0508 \\
(0.0722)\end{array}$ & $\begin{array}{c}0.00920 \\
(0.00931)\end{array}$ & $\begin{array}{c}-0.0456 \\
(0.103)\end{array}$ & $\begin{array}{l}-0.00399 \\
(0.00354)\end{array}$ & $\begin{array}{c}0.0763 \\
(0.0821)\end{array}$ & $\begin{array}{l}0.00202 \\
(0.0121)\end{array}$ & $\begin{array}{l}0.0163 \\
(0.158)\end{array}$ & $\begin{array}{l}-0.00253 \\
(0.00253)\end{array}$ \\
\hline Effect in 2000 & $\begin{array}{c}0.0432 \\
(0.0972)\end{array}$ & $\begin{array}{l}-0.0759 \\
(0.0724)\end{array}$ & $\begin{array}{c}-0.0694 \\
(0.109)\end{array}$ & $\begin{array}{r}-0.000177 \\
(0.00291)\end{array}$ & $\begin{array}{c}0.0730 \\
(0.1000)\end{array}$ & $\begin{array}{l}-0.0825 \\
(0.0706)\end{array}$ & $\begin{array}{c}-0.0322 \\
(0.163)\end{array}$ & $\begin{array}{l}-0.00112 \\
(0.00135)\end{array}$ \\
\hline Effect in 2001 & $\begin{array}{c}0.0752 \\
(0.0559)\end{array}$ & $\begin{array}{c}-0.00510 \\
(0.0101)\end{array}$ & $\begin{array}{c}-0.0422 \\
(0.112)\end{array}$ & $\begin{array}{l}-0.00177 \\
(0.00293)\end{array}$ & $\begin{array}{c}0.108 \\
(0.0721)\end{array}$ & $\begin{array}{l}-0.0111 \\
(0.0123)\end{array}$ & $\begin{array}{c}-0.0578 \\
(0.105)\end{array}$ & $\begin{array}{l}-0.00149 \\
(0.00137)\end{array}$ \\
\hline Effect in 2002 & $\begin{array}{c}0.0710 \\
(0.0510)\end{array}$ & $\begin{array}{c}-0.0106 \\
(0.00908)\end{array}$ & $\begin{array}{l}0.0728 \\
(0.103)\end{array}$ & $\begin{array}{r}-5.14 e-05 \\
(0.00304)\end{array}$ & $\begin{array}{c}0.109 \\
(0.0681)\end{array}$ & $\begin{array}{l}-0.0159 \\
(0.0116)\end{array}$ & $\begin{array}{l}0.0471 \\
(0.117)\end{array}$ & $\begin{array}{l}0.000458 \\
(0.00166)\end{array}$ \\
\hline Effect in 2003 & $\begin{array}{c}0.0608 \\
(0.0516)\end{array}$ & $\begin{array}{c}-0.000425 \\
(0.0121)\end{array}$ & $\begin{array}{c}0.121 \\
(0.103)\end{array}$ & $\begin{array}{r}-0.000950 \\
(0.00273)\end{array}$ & $\begin{array}{c}0.102 \\
(0.0668)\end{array}$ & $\begin{array}{c}-0.00522 \\
(0.0144)\end{array}$ & $\begin{array}{c}0.142 \\
(0.118)\end{array}$ & $\begin{array}{c}-0.000398 \\
(0.00135)\end{array}$ \\
\hline Effect in 2004 & $\begin{array}{c}0.0246 \\
(0.0589)\end{array}$ & $\begin{array}{l}-0.0204 \\
(0.0127)\end{array}$ & $\begin{array}{c}0.168 \\
(0.117)\end{array}$ & $\begin{array}{c}5.31 e-05 \\
(0.00289)\end{array}$ & $\begin{array}{c}0.0702 \\
(0.0713)\end{array}$ & $\begin{array}{l}-0.0244 \\
(0.0157)\end{array}$ & $\begin{array}{l}0.0938 \\
(0.125)\end{array}$ & $\begin{array}{r}-0.000715 \\
(0.00148)\end{array}$ \\
\hline Effect in 2005 & $\begin{array}{c}0.0122 \\
(0.0498)\end{array}$ & $\begin{array}{l}-0.0272^{\star} \\
(0.0153)\end{array}$ & $\begin{array}{c}0.117 \\
(0.112)\end{array}$ & $\begin{array}{l}0.001000 \\
(0.00301)\end{array}$ & $\begin{array}{c}0.0626 \\
(0.0652)\end{array}$ & $\begin{array}{l}-0.0305^{\star} \\
(0.0180)\end{array}$ & $\begin{array}{l}0.0483 \\
(0.107)\end{array}$ & $\begin{array}{l}-0.00234 \\
(0.00201)\end{array}$ \\
\hline Effect in 2006 & $\begin{array}{l}-0.0647 \\
(0.0567)\end{array}$ & $\begin{array}{c}-0.0535^{\star \star \star} \\
(0.0165)\end{array}$ & $\begin{array}{l}0.0128 \\
(0.117)\end{array}$ & $\begin{array}{l}-0.00271 \\
(0.00291)\end{array}$ & $\begin{array}{l}-0.0138 \\
(0.0709)\end{array}$ & $\begin{array}{c}-0.0567^{\star \star \star} \\
(0.0187)\end{array}$ & $\begin{array}{l}0.0195 \\
(0.115)\end{array}$ & $\begin{array}{r}-0.000935 \\
(0.00151)\end{array}$ \\
\hline Domestic Capital & $\begin{array}{l}0.0196^{\star \star \star} \\
(0.00450)\end{array}$ & & $\begin{array}{c}-0.0182 \\
(0.0300)\end{array}$ & & $\begin{array}{l}0.0196^{\star \star \star} \\
(0.00450)\end{array}$ & & $\begin{array}{c}0.0855^{\star} \\
(0.0491)\end{array}$ & \\
\hline Imported Capital & $\begin{array}{c}0.0186 * \star \\
(0.00907)\end{array}$ & & $\begin{array}{c}0.000187 \\
(0.0319)\end{array}$ & & $\begin{array}{c}0.0187^{\star \star} \\
(0.00907)\end{array}$ & & $\begin{array}{c}0.0627 \\
(0.0451)\end{array}$ & \\
\hline Imported Input & $\begin{array}{l}0.440 * \star * \\
(0.0970)\end{array}$ & $\begin{array}{c}0.0775^{\star \star *} \\
(0.0224)\end{array}$ & $\begin{array}{c}0.673^{\star * *} \\
(0.184)\end{array}$ & $\begin{array}{c}0.00105 \\
(0.00408)\end{array}$ & $\begin{array}{l}0.439^{\star \star *} \\
(0.0970)\end{array}$ & $\begin{array}{c}0.0774^{\star \star \star} \\
(0.0224)\end{array}$ & $\begin{array}{l}0.686^{\star *} \\
(0.337)\end{array}$ & $\begin{array}{c}0.00234 \\
(0.00177)\end{array}$ \\
\hline Export Coefficient & $\begin{array}{l}0.206^{\star \star \star} \\
(0.0387)\end{array}$ & $\begin{array}{l}0.00220 \\
(0.0135)\end{array}$ & $\begin{array}{l}-0.373^{\star \star \star} \\
(0.0943)\end{array}$ & $\begin{array}{l}-0.0126 \\
(0.0179)\end{array}$ & $\begin{array}{l}0.206^{\star \star *} \\
(0.0387)\end{array}$ & $\begin{array}{l}0.00221 \\
(0.0135)\end{array}$ & $\begin{array}{c}0.141 \\
(0.0953)\end{array}$ & $\begin{array}{c}0.00284^{*} \\
(0.00166)\end{array}$ \\
\hline Import Coefficient & $\begin{array}{c}-1.218^{\star \star \star} \\
(0.164)\end{array}$ & $\begin{array}{l}-0.115^{\star \star \star} \\
(0.0335)\end{array}$ & $\begin{array}{l}-0.671^{\star \star} \\
(0.278)\end{array}$ & $\begin{array}{l}-0.0119 \\
(0.0103)\end{array}$ & $\begin{array}{c}-1.218^{\star \star \star} \\
(0.164)\end{array}$ & $\begin{array}{l}-0.115^{\star \star *} \\
(0.0335)\end{array}$ & $\begin{array}{c}-1.924^{\star * *} \\
(0.590)\end{array}$ & $\begin{array}{c}-0.00763^{\star \star *} \\
(0.00222)\end{array}$ \\
\hline Net Sales Revenue & $\begin{array}{c}0.495^{\star * *} \\
(0.00491)\end{array}$ & $\begin{array}{l}-0.0470^{\star * \star} \\
(0.00884)\end{array}$ & $\begin{array}{l}0.625^{\star \star \star} \\
(0.0242)\end{array}$ & $\begin{array}{l}0.00265^{\star \star \star} \\
(0.000551)\end{array}$ & $\begin{array}{c}0.495^{\star * *} \\
(0.00491)\end{array}$ & $\begin{array}{c}-0.0470 * * * \\
(0.00884)\end{array}$ & $\begin{array}{l}0.591^{\star \star \star} \\
(0.0352)\end{array}$ & $\begin{array}{c}-0.00286^{\star \star *} \\
(0.000368)\end{array}$ \\
\hline Number of Employees & $\begin{array}{l}-0.422^{\star * *} \\
(0.00668)\end{array}$ & & $\begin{array}{l}-0.643^{* * *} \\
(0.0478)\end{array}$ & & $\begin{array}{l}-0.422^{\star \star \star} \\
(0.00668)\end{array}$ & & $\begin{array}{l}-0.568^{\star * *} \\
(0.0482)\end{array}$ & \\
\hline Cost / Revenue & $\begin{array}{l}-2.010^{\star * *} \\
(0.0750)\end{array}$ & $\begin{array}{l}-0.163^{\star \star \star} \\
(0.0433)\end{array}$ & $\begin{array}{c}-2.106^{\star \star \star} \\
(0.221)\end{array}$ & $\begin{array}{c}-0.0329 * \star * \\
(0.0109)\end{array}$ & $\begin{array}{l}-2.010^{\star * \star} \\
(0.0750)\end{array}$ & $\begin{array}{l}-0.163^{\star \star *} \\
(0.0433)\end{array}$ & $\begin{array}{c}-1.809 * \star * \\
(0.299)\end{array}$ & $\begin{array}{c}-0.0193^{\star \star *} \\
(0.00705)\end{array}$ \\
\hline Firms' Age & $\begin{array}{l}-0.0175^{\star * *} \\
(0.00380)\end{array}$ & $\begin{array}{c}-0.0817^{\star \star \star} \\
(0.0282)\end{array}$ & $\begin{array}{l}0.0840^{* *} \\
(0.0334)\end{array}$ & $\begin{array}{l}-0.00554 \\
(0.00366)\end{array}$ & $\begin{array}{l}-0.0175^{\star \star \star} \\
(0.00380)\end{array}$ & $\begin{array}{c}-0.0817^{\star * *} \\
(0.0282)\end{array}$ & $\begin{array}{l}-0.104^{\star \star} \\
(0.0529)\end{array}$ & $\begin{array}{l}-0.00216^{\star * *} \\
(0.000672)\end{array}$ \\
\hline Years of Schooling & $\begin{array}{l}-0.0171^{*} \\
(0.00971)\end{array}$ & $\begin{array}{l}-0.0197 \\
(0.0142)\end{array}$ & $\begin{array}{c}-0.122 \\
(0.0796)\end{array}$ & $\begin{array}{c}0.00516 \\
(0.00869)\end{array}$ & $\begin{array}{l}-0.0172^{*} \\
(0.00971)\end{array}$ & $\begin{array}{l}-0.0197 \\
(0.0142)\end{array}$ & $\begin{array}{c}-0.105 \\
(0.0745)\end{array}$ & $\begin{array}{r}-0.000634 \\
(0.00163)\end{array}$ \\
\hline Skilled Labor & $\begin{array}{l}0.316^{\star * \star} \\
(0.0351)\end{array}$ & $\begin{array}{c}0.0203 \\
(0.0441)\end{array}$ & $\begin{array}{l}0.678^{\star \star *} \\
(0.185)\end{array}$ & $\begin{array}{c}-0.00718 \\
(0.0102)\end{array}$ & $\begin{array}{l}0.317^{\star * *} \\
(0.0351)\end{array}$ & $\begin{array}{c}0.0205 \\
(0.0441)\end{array}$ & $\begin{array}{c}0.676^{\star \star \star} \\
(0.174)\end{array}$ & $\begin{array}{c}0.00361 \\
(0.00252)\end{array}$ \\
\hline Average Salary & $\begin{array}{c}0.567^{\star \star \star} \\
(0.00683)\end{array}$ & $\begin{array}{c}0.0535^{\star \star \star} \\
(0.0118)\end{array}$ & $\begin{array}{l}0.287^{\star * *} \\
(0.0401)\end{array}$ & $\begin{array}{l}0.000431 \\
(0.00105)\end{array}$ & $\begin{array}{c}0.567^{\star * *} \\
(0.00683)\end{array}$ & $\begin{array}{c}0.0535^{\star \star \star} \\
(0.0118)\end{array}$ & $\begin{array}{l}0.426^{\star \star \star} \\
(0.0534)\end{array}$ & $\begin{array}{c}0.000753 \\
(0.000933)\end{array}$ \\
\hline Investment & $\begin{array}{c}0.0104^{\star \star \star} \\
(0.000422)\end{array}$ & $\begin{array}{l}-0.00394^{\star * *} \\
(0.000927)\end{array}$ & $\begin{array}{l}0.0150^{\star * \star} \\
(0.00289)\end{array}$ & $\begin{array}{c}5.20 \mathrm{e}-05 \\
(0.000255)\end{array}$ & $\begin{array}{c}0.0104^{\star \star \star} \\
(0.000422)\end{array}$ & $\begin{array}{l}-0.00394^{\star \star \star} \\
(0.000927)\end{array}$ & $\begin{array}{l}0.0174^{\star \star \star} \\
(0.00445)\end{array}$ & $\begin{array}{c}-0.000111^{*} \\
(5.96 \mathrm{e}-05)\end{array}$ \\
\hline Solvency & $\begin{array}{l}1.272^{\star \star *} \\
(0.0855)\end{array}$ & $\begin{array}{c}0.0107 \\
(0.0273)\end{array}$ & $\begin{array}{c}1.212^{\star \star \star} \\
(0.170)\end{array}$ & $\begin{array}{l}0.0231^{\star \star} \\
(0.0114)\end{array}$ & $\begin{array}{l}1.272^{\star \star \star} \\
(0.0855)\end{array}$ & $\begin{array}{c}0.0107 \\
(0.0273)\end{array}$ & $\begin{array}{c}2.279 * \star \star \\
(0.399)\end{array}$ & $\begin{array}{l}0.0239 * \\
(0.0144)\end{array}$ \\
\hline Revenue Growth & $\begin{array}{l}-0.461^{\star * *} \\
(0.0126)\end{array}$ & $\begin{array}{l}0.0176^{\star \star \star} \\
(0.00591)\end{array}$ & $\begin{array}{l}-0.343^{\star \star \star} \\
(0.0729)\end{array}$ & $\begin{array}{c}-0.000823 \\
(0.00291)\end{array}$ & $\begin{array}{l}-0.461^{* \star *} \\
(0.0126)\end{array}$ & $\begin{array}{l}0.0176^{\star \star \star} \\
(0.00591)\end{array}$ & $\begin{array}{l}-0.361^{\star *} \\
(0.146)\end{array}$ & $\begin{array}{c}0.00149 \\
(0.00123)\end{array}$ \\
\hline
\end{tabular}




\begin{tabular}{|c|c|c|c|c|c|c|c|c|}
\hline \multicolumn{9}{|c|}{ Table A.5.b: Results of Difference-in-Differences (Just Once) - Continuation } \\
\hline Employment Growth & $\begin{array}{l}0.463^{* * *} \\
(0.0118)\end{array}$ & $\begin{array}{c}0.0187 \\
(0.0223)\end{array}$ & $\begin{array}{l}0.273^{\star * *} \\
(0.0905)\end{array}$ & $\begin{array}{l}0.000367 \\
(0.00144)\end{array}$ & $\begin{array}{l}0.463^{\star * *} \\
(0.0118)\end{array}$ & $\begin{array}{c}0.0187 \\
(0.0223)\end{array}$ & $\begin{array}{l}0.415^{\star \star} \\
(0.167)\end{array}$ & $\begin{array}{l}-0.000180 \\
(0.000933)\end{array}$ \\
\hline Productivity Growth & $\begin{array}{c}0.492^{\star \star \star} \\
(0.00994)\end{array}$ & $\begin{array}{c}0.000671 \\
(0.000568)\end{array}$ & $\begin{array}{l}0.411^{\star * *} \\
(0.0678)\end{array}$ & $\begin{array}{c}0.000273 \\
(0.000645)\end{array}$ & $\begin{array}{c}0.492^{\star \star \star} \\
(0.00994)\end{array}$ & $\begin{array}{c}0.000670 \\
(0.000568)\end{array}$ & $\begin{array}{c}0.476^{\star \star \star} \\
(0.151)\end{array}$ & $\begin{array}{l}0.000301 * \\
(0.000173)\end{array}$ \\
\hline Profitable & $\begin{array}{c}0.171^{\star * \star} \\
(0.00773)\end{array}$ & $\begin{array}{l}-0.00538 \\
(0.00948)\end{array}$ & $\begin{array}{l}0.0451^{*} \\
(0.0241)\end{array}$ & $\begin{array}{l}-0.00158 \\
(0.00164)\end{array}$ & $\begin{array}{c}0.171^{\star * \star} \\
(0.00773)\end{array}$ & $\begin{array}{l}-0.00537 \\
(0.00948)\end{array}$ & $\begin{array}{l}0.101^{\star \star *} \\
(0.0318)\end{array}$ & $\begin{array}{l}-0.000238 \\
(0.000615)\end{array}$ \\
\hline Multinational Status & $\begin{array}{c}0.0504^{\star \star \star} \\
(0.0110)\end{array}$ & $\begin{array}{l}0.0116^{\star * *} \\
(0.00368)\end{array}$ & $\begin{array}{c}0.0334 \\
(0.0540)\end{array}$ & $\begin{array}{c}0.00490 \\
(0.00343)\end{array}$ & $\begin{array}{c}0.0502^{\star \star \star} \\
(0.0110)\end{array}$ & $\begin{array}{l}0.0116^{\star \star \star} \\
(0.00367)\end{array}$ & $\begin{array}{c}0.0490 \\
(0.0609)\end{array}$ & $\begin{array}{l}0.00266^{\star \star \star} \\
(0.000839)\end{array}$ \\
\hline Year Dummy & Yes & Yes & Yes & Yes & Yes & Yes & Yes & Yes \\
\hline OCDE Dummy & Yes & Yes & Yes & Yes & Yes & Yes & Yes & Yes \\
\hline Size Dummy & Yes & Yes & Yes & Yes & Yes & Yes & Yes & Yes \\
\hline Sector Dummy & Yes & Yes & Yes & Yes & Yes & Yes & Yes & Yes \\
\hline Region Dummy & Yes & Yes & Yes & Yes & Yes & Yes & Yes & Yes \\
\hline Observations & 203.128 & 175.677 & 1.203 & 1.189 & 203.150 & 175.696 & 1.674 & 1.661 \\
\hline R-squared & 0.693 & 0.11 & 0.870 & 0.191 & 0.693 & 0.481 & 0.761 & 0.391 \\
\hline
\end{tabular}

Robust standard errors in parentheses

${ }^{* * \star} p<0.01,{ }^{* *} p<0.05,{ }^{*} p<0.1$ 


\begin{tabular}{|c|c|c|c|c|c|c|c|c|}
\hline \multicolumn{9}{|c|}{ Table A.5.c: Results of Difference-in-Differences (Automatic BNDES) } \\
\hline \multirow{3}{*}{$\begin{array}{l}\text { Treated Group } \\
\text { Control Group } \\
\text { Dependent Variable }\end{array}$} & \multicolumn{4}{|c|}{ Group 5} & \multicolumn{4}{|c|}{ Group 6} \\
\hline & \multicolumn{2}{|c|}{ Group A } & \multicolumn{2}{|c|}{ Paired } & \multicolumn{2}{|c|}{ Group A } & \multicolumn{2}{|c|}{ Paired } \\
\hline & Labor & TFP & Labor & TFP & Labor & TFP & Labor & TFP \\
\hline Effect in 1998 & $\begin{array}{c}0.137^{\star \star} \\
(0.0665)\end{array}$ & $\begin{array}{c}0.00210 \\
(0.00930)\end{array}$ & $\begin{array}{c}0.0555 \\
(0.0960)\end{array}$ & $\begin{array}{c}0.00610 \\
(0.00524)\end{array}$ & $\begin{array}{c}0.0966^{*} \\
(0.0579)\end{array}$ & $\begin{array}{c}0.0127 \\
(0.00941)\end{array}$ & $\begin{array}{l}0.0527 \\
(0.108)\end{array}$ & $\begin{array}{r}-0.000609 \\
(0.00199)\end{array}$ \\
\hline Effect in 1999 & $\begin{array}{l}0.160^{\star * *} \\
(0.0618)\end{array}$ & $\begin{array}{l}-0.00361 \\
(0.00954)\end{array}$ & $\begin{array}{c}0.0425 \\
(0.0917)\end{array}$ & $\begin{array}{c}0.00423 \\
(0.00466)\end{array}$ & $\begin{array}{c}0.0935 \\
(0.0658)\end{array}$ & $\begin{array}{l}0.00447 \\
(0.0113)\end{array}$ & $\begin{array}{l}0.0831 \\
(0.148)\end{array}$ & $\begin{array}{l}-0.00343^{*} \\
(0.00204)\end{array}$ \\
\hline Effect in 2000 & $\begin{array}{l}0.195^{\star * *} \\
(0.0610)\end{array}$ & $\begin{array}{l}-0.0851 \\
(0.0711)\end{array}$ & $\begin{array}{c}-0.0159 \\
(0.102)\end{array}$ & $\begin{array}{c}0.00265 \\
(0.00445)\end{array}$ & $\begin{array}{c}0.125 \\
(0.0763)\end{array}$ & $\begin{array}{l}-0.0800 \\
(0.0684)\end{array}$ & $\begin{array}{l}0.0633 \\
(0.141)\end{array}$ & $\begin{array}{l}-0.00204 \\
(0.00124)\end{array}$ \\
\hline Effect in 2001 & $\begin{array}{c}0.161^{\star *} \\
(0.0631)\end{array}$ & $\begin{array}{l}-0.0140 \\
(0.0111)\end{array}$ & $\begin{array}{c}-0.00923 \\
(0.102)\end{array}$ & $\begin{array}{c}0.00222 \\
(0.00444)\end{array}$ & $\begin{array}{c}0.137^{\star *} \\
(0.0556)\end{array}$ & $\begin{array}{c}-0.00905 \\
(0.0113)\end{array}$ & $\begin{array}{l}-0.0236 \\
(0.0843)\end{array}$ & $\begin{array}{c}-0.00252^{\star *} \\
(0.00126)\end{array}$ \\
\hline Effect in 2002 & $\begin{array}{l}0.158^{\star \star} \\
(0.0634)\end{array}$ & $\begin{array}{l}-0.0176^{*} \\
(0.0103)\end{array}$ & $\begin{array}{c}0.000578 \\
(0.0974)\end{array}$ & $\begin{array}{c}0.00471 \\
(0.00475)\end{array}$ & $\begin{array}{c}0.108 * * \\
(0.0548)\end{array}$ & $\begin{array}{l}-0.0118 \\
(0.0109)\end{array}$ & $\begin{array}{c}0.0599 \\
(0.0952)\end{array}$ & $\begin{array}{l}-0.00133 \\
(0.00141)\end{array}$ \\
\hline Effect in 2003 & $\begin{array}{c}0.105^{\star} \\
(0.0610)\end{array}$ & $\begin{array}{l}-0.0138 \\
(0.0107)\end{array}$ & $\begin{array}{c}0.0414 \\
(0.0959)\end{array}$ & $\begin{array}{c}0.00301 \\
(0.00432)\end{array}$ & $\begin{array}{c}0.0491 \\
(0.0571)\end{array}$ & $\begin{array}{l}-0.00850 \\
(0.0125)\end{array}$ & $\begin{array}{c}0.0241 \\
(0.0974)\end{array}$ & $\begin{array}{l}-0.00230 * \\
(0.00125)\end{array}$ \\
\hline Effect in 2004 & $\begin{array}{c}0.0834 \\
(0.0680)\end{array}$ & $\begin{array}{c}-0.0297^{\star \star} \\
(0.0126)\end{array}$ & $\begin{array}{l}0.00902 \\
(0.0961)\end{array}$ & $\begin{array}{c}0.00198 \\
(0.00484)\end{array}$ & $\begin{array}{c}0.0282 \\
(0.0622)\end{array}$ & $\begin{array}{l}-0.0261^{*} \\
(0.0135)\end{array}$ & $\begin{array}{l}0.00137 \\
(0.0972)\end{array}$ & $\begin{array}{c}-0.00259^{*} \\
(0.00135)\end{array}$ \\
\hline Effect in 2005 & $\begin{array}{c}0.0429 \\
(0.0687)\end{array}$ & $\begin{array}{l}-0.0326^{\star} \\
(0.0167)\end{array}$ & $\begin{array}{c}0.0174 \\
(0.0943)\end{array}$ & $\begin{array}{l}0.000529 \\
(0.00498)\end{array}$ & $\begin{array}{c}0.0122 \\
(0.0594)\end{array}$ & $\begin{array}{l}-0.0289 \\
(0.0176)\end{array}$ & $\begin{array}{l}-0.0245 \\
(0.0887)\end{array}$ & $\begin{array}{c}-0.00359 * * \\
(0.00168)\end{array}$ \\
\hline Effect in 2006 & $\begin{array}{c}0.0196 \\
(0.0667)\end{array}$ & $\begin{array}{c}-0.0537^{\star \star \star} \\
(0.0176)\end{array}$ & $\begin{array}{r}-0.0211 \\
(0.108)\end{array}$ & $\begin{array}{c}0.00241 \\
(0.00427)\end{array}$ & $\begin{array}{l}-0.0120 \\
(0.0587)\end{array}$ & $\begin{array}{c}-0.0499 * * * \\
(0.0186)\end{array}$ & $\begin{array}{l}-0.0513 \\
(0.0881)\end{array}$ & $\begin{array}{c}-0.00301^{\star *} \\
(0.00139)\end{array}$ \\
\hline Multiple Treatments & $\begin{array}{c}0.0160 \\
(0.0106)\end{array}$ & $\begin{array}{l}0.00620^{\star *} \\
(0.00298)\end{array}$ & $\begin{array}{c}0.0378^{\star * *} \\
(0.0111)\end{array}$ & $\begin{array}{r}0.00000867 \\
(0.000140)\end{array}$ & $\begin{array}{c}0.0294^{\star \star *} \\
(0.0110)\end{array}$ & $\begin{array}{c}0.00889^{\star * \star} \\
(0.00345)\end{array}$ & $\begin{array}{c}0.0378^{\star \star *} \\
(0.0111)\end{array}$ & $\begin{array}{c}8.67 e-05 \\
(0.000140)\end{array}$ \\
\hline Domestic Capital & $\begin{array}{l}0.0193^{\star * *} \\
(0.00451)\end{array}$ & & $\begin{array}{c}0.0364 \\
(0.0266)\end{array}$ & & $\begin{array}{l}0.0189 * * * \\
(0.00450)\end{array}$ & & $\begin{array}{c}0.000122 \\
(0.0368)\end{array}$ & \\
\hline Imported Capital & $\begin{array}{c}0.0183^{\star *} \\
(0.00904)\end{array}$ & & $\begin{array}{c}0.0478 \\
(0.0342)\end{array}$ & & $\begin{array}{c}0.0188^{\star \star} \\
(0.00906)\end{array}$ & & $\begin{array}{c}0.0664 \\
(0.0426)\end{array}$ & \\
\hline Imported Input & $\begin{array}{l}0.435^{\star \star \star} \\
(0.0964)\end{array}$ & $\begin{array}{c}0.0779 * \star * \\
(0.0224)\end{array}$ & $\begin{array}{c}0.828^{\star \star \star} \\
(0.279)\end{array}$ & $\begin{array}{c}0.00184 \\
(0.00388)\end{array}$ & $\begin{array}{l}0.437^{\star \star \star} \\
(0.0967)\end{array}$ & $\begin{array}{c}0.0775^{\star \star \star} \\
(0.0224)\end{array}$ & $\begin{array}{l}0.652^{\star \star} \\
(0.322)\end{array}$ & $\begin{array}{c}0.00825^{\star \star \star} \\
(0.00260)\end{array}$ \\
\hline Export Coefficient & $\begin{array}{l}0.205^{\star \star *} \\
(0.0384)\end{array}$ & $\begin{array}{l}0.00199 \\
(0.0133)\end{array}$ & $\begin{array}{l}0.263^{\star * *} \\
(0.0725)\end{array}$ & $\begin{array}{c}0.00253 \\
(0.00189)\end{array}$ & $\begin{array}{l}0.205^{\star \star \star} \\
(0.0386)\end{array}$ & $\begin{array}{l}0.00197 \\
(0.0133)\end{array}$ & $\begin{array}{c}0.131^{*} \\
(0.0738)\end{array}$ & $\begin{array}{c}0.00200 \\
(0.00124)\end{array}$ \\
\hline Import Coefficient & $\begin{array}{c}-1.211^{\star \star \star} \\
(0.163)\end{array}$ & $\begin{array}{c}-0.115^{\star \star \star} \\
(0.0337)\end{array}$ & $\begin{array}{l}-0.759^{\star} \\
(0.452)\end{array}$ & $\begin{array}{l}-0.00377 \\
(0.00704)\end{array}$ & $\begin{array}{c}-1.216^{\star \star \star} \\
(0.164)\end{array}$ & $\begin{array}{l}-0.115^{\star \star \star} \\
(0.0334)\end{array}$ & $\begin{array}{c}-1.287^{\star \star} \\
(0.649)\end{array}$ & $\begin{array}{c}-0.0122^{\star \star *} \\
(0.00260)\end{array}$ \\
\hline Net Sales Revenue & $\begin{array}{c}0.496^{\star \star \star} \\
(0.00490)\end{array}$ & $\begin{array}{c}-0.0470^{\star \star \star} \\
(0.00883)\end{array}$ & $\begin{array}{l}0.593^{\star * *} \\
(0.0203)\end{array}$ & $\begin{array}{c}-0.00434^{\star \star *} \\
(0.000560)\end{array}$ & $\begin{array}{c}0.496^{\star * *} \\
(0.00490)\end{array}$ & $\begin{array}{c}-0.0469 \star \star \star \\
(0.00882)\end{array}$ & $\begin{array}{l}0.628^{* * *} \\
(0.0289)\end{array}$ & $\begin{array}{c}-0.00311^{\star \star *} \\
(0.000348)\end{array}$ \\
\hline Number of Employees & $\begin{array}{l}-0.422^{\star \star \star} \\
(0.00668)\end{array}$ & & $\begin{array}{l}-0.563^{\star \star \star} \\
(0.0331)\end{array}$ & & $\begin{array}{l}-0.422^{\star \star *} \\
(0.00667)\end{array}$ & & $\begin{array}{c}-0.526^{\star \star \star} \\
(0.0434)\end{array}$ & \\
\hline Cost / Revenue & $\begin{array}{c}-2.011^{\star \star \star} \\
(0.0751)\end{array}$ & $\begin{array}{c}-0.163^{\star \star \star} \\
(0.0433)\end{array}$ & $\begin{array}{c}-1.822^{\star \star \star} \\
(0.187)\end{array}$ & $\begin{array}{l}-0.0204^{\star * \star} \\
(0.00634)\end{array}$ & $\begin{array}{l}-2.009 \star \star \star \\
(0.0749)\end{array}$ & $\begin{array}{l}-0.163^{\star \star \star} \\
(0.0432)\end{array}$ & $\begin{array}{c}-1.563^{\star \star \star} \\
(0.264)\end{array}$ & $\begin{array}{c}-0.0181^{\star \star *} \\
(0.00576)\end{array}$ \\
\hline Firms' Age & $\begin{array}{c}-0.0175^{\star \star \star} \\
(0.00380)\end{array}$ & $\begin{array}{c}-0.0817^{\star \star \star} \\
(0.0283)\end{array}$ & $\begin{array}{l}-0.0217 \\
(0.0246)\end{array}$ & $\begin{array}{c}-0.00348^{\star \star} \\
(0.00145)\end{array}$ & $\begin{array}{c}-0.0176^{\star \star \star} \\
(0.00380)\end{array}$ & $\begin{array}{c}-0.0816^{\star \star \star} \\
(0.0282)\end{array}$ & $\begin{array}{l}-0.112^{\star \star} \\
(0.0455)\end{array}$ & $\begin{array}{c}-0.00185^{\star \star *} \\
(0.000504)\end{array}$ \\
\hline Years of Schooling & $\begin{array}{c}-0.0164^{*} \\
(0.00972)\end{array}$ & $\begin{array}{l}-0.0196 \\
(0.0142)\end{array}$ & $\begin{array}{l}0.187^{\star \star \star} \\
(0.0696)\end{array}$ & $\begin{array}{c}0.00430 \\
(0.00352)\end{array}$ & $\begin{array}{c}-0.0165^{\star} \\
(0.00972)\end{array}$ & $\begin{array}{l}-0.0196 \\
(0.0142)\end{array}$ & $\begin{array}{c}-0.103 \\
(0.0716)\end{array}$ & $\begin{array}{l}0.000700 \\
(0.00121)\end{array}$ \\
\hline Skilled Labor & $\begin{array}{l}0.311^{\star \star \star} \\
(0.0351)\end{array}$ & $\begin{array}{c}0.0195 \\
(0.0436)\end{array}$ & $\begin{array}{l}0.365^{\star \star} \\
(0.182)\end{array}$ & $\begin{array}{c}0.00303 \\
(0.00369)\end{array}$ & $\begin{array}{l}0.314^{\star \star *} \\
(0.0351)\end{array}$ & $\begin{array}{c}0.0197 \\
(0.0437)\end{array}$ & $\begin{array}{c}0.733^{\star \star \star} \\
(0.172)\end{array}$ & $\begin{array}{r}-0.000866 \\
(0.00203)\end{array}$ \\
\hline Average Salary & $\begin{array}{c}0.567^{\star * *} \\
(0.00683)\end{array}$ & $\begin{array}{c}0.0535^{\star \star *} \\
(0.0118)\end{array}$ & $\begin{array}{l}0.373^{\star \star *} \\
(0.0285)\end{array}$ & $\begin{array}{l}0.000367 \\
(0.00161)\end{array}$ & $\begin{array}{c}0.566^{\star \star *} \\
(0.00682)\end{array}$ & $\begin{array}{c}0.0535^{\star \star \star} \\
(0.0118)\end{array}$ & $\begin{array}{l}0.390 * * * \\
(0.0412)\end{array}$ & $\begin{array}{c}0.000833 \\
(0.000693)\end{array}$ \\
\hline Investment & $\begin{array}{c}0.0103^{\star \star \star} \\
(0.000421)\end{array}$ & $\begin{array}{c}-0.00394^{\star * *} \\
(0.000930)\end{array}$ & $\begin{array}{c}0.00329 \\
(0.00238)\end{array}$ & $\begin{array}{c}-0.000254^{\star *} \\
(0.000106)\end{array}$ & $\begin{array}{c}0.0104^{\star \star \star} \\
(0.000421)\end{array}$ & $\begin{array}{c}-0.00393^{\star * *} \\
(0.000927)\end{array}$ & $\begin{array}{l}0.0177^{\star \star \star} \\
(0.00343)\end{array}$ & $\begin{array}{c}-0.000129^{* * *} \\
(4.87 e-05)\end{array}$ \\
\hline Solvency & $\begin{array}{l}1.271^{\star \star *} \\
(0.0857)\end{array}$ & $\begin{array}{c}0.0105 \\
(0.0274)\end{array}$ & $\begin{array}{c}1.505^{\star \star \star} \\
(0.282)\end{array}$ & $\begin{array}{c}0.00277 \\
(0.00501)\end{array}$ & $\begin{array}{l}1.269^{\star \star *} \\
(0.0855)\end{array}$ & $\begin{array}{c}0.0105 \\
(0.0273)\end{array}$ & $\begin{array}{c}1.655^{\star \star \star} \\
(0.388)\end{array}$ & $\begin{array}{c}0.0126 \\
(0.00985)\end{array}$ \\
\hline Revenue Growth & $\begin{array}{l}-0.462^{\star \star \star} \\
(0.0126)\end{array}$ & $\begin{array}{l}0.0176^{\star * *} \\
(0.00593)\end{array}$ & $\begin{array}{c}-0.373^{\star \star *} \\
(0.0911)\end{array}$ & $\begin{array}{l}0.00246^{\star *} \\
(0.00101)\end{array}$ & $\begin{array}{c}-0.461^{\star * *} \\
(0.0126)\end{array}$ & $\begin{array}{l}0.0176^{\star * *} \\
(0.00591)\end{array}$ & $\begin{array}{c}-0.370 \star \star * \\
(0.130)\end{array}$ & $\begin{array}{c}0.00189 * * \\
(0.000956)\end{array}$ \\
\hline
\end{tabular}


Table A.5.c: Results of Difference-in-Differences (Automatic BNDES) - Continuation

\begin{tabular}{|c|c|c|c|c|c|c|c|c|}
\hline Employment Growth & $\begin{array}{l}0.463^{\star \star \star} \\
(0.0118)\end{array}$ & $\begin{array}{c}0.0187 \\
(0.0223)\end{array}$ & $\begin{array}{l}0.397^{\star * *} \\
(0.0931)\end{array}$ & $\begin{array}{l}-0.00419 \\
(0.00307)\end{array}$ & $\begin{array}{l}0.463^{\star \star \star} \\
(0.0117)\end{array}$ & $\begin{array}{c}0.0187 \\
(0.0222)\end{array}$ & $\begin{array}{c}0.436^{\star \star \star} \\
(0.136)\end{array}$ & $\begin{array}{c}-0.000392 \\
(0.000775)\end{array}$ \\
\hline Productivity Growth & $\begin{array}{c}0.492^{\star \star \star} \\
(0.00995)\end{array}$ & $\begin{array}{c}0.000688 \\
(0.000565)\end{array}$ & $\begin{array}{l}0.428^{* * *} \\
(0.0677)\end{array}$ & $\begin{array}{c}0.000131 \\
(0.000494)\end{array}$ & $\begin{array}{c}0.492^{\star \star \star} \\
(0.00994)\end{array}$ & $\begin{array}{c}0.000689 \\
(0.000563)\end{array}$ & $\begin{array}{c}0.486^{\star \star \star} \\
(0.137)\end{array}$ & $\begin{array}{l}0.000302^{* *} \\
(0.000142)\end{array}$ \\
\hline Profitable & $\begin{array}{c}0.171^{\star \star \star} \\
(0.00773)\end{array}$ & $\begin{array}{l}-0.00537 \\
(0.00948)\end{array}$ & $\begin{array}{l}0.00879 \\
(0.0241)\end{array}$ & $\begin{array}{c}0.00147^{*} \\
(0.000848)\end{array}$ & $\begin{array}{l}0.171^{\star \star \star} \\
(0.00771)\end{array}$ & $\begin{array}{l}-0.00536 \\
(0.00944)\end{array}$ & $\begin{array}{c}0.0756^{\star \star \star} \\
(0.0251)\end{array}$ & $\begin{array}{l}-0.000296 \\
(0.000481)\end{array}$ \\
\hline Multinational Status & $\begin{array}{c}0.0516 \text { *** } \\
(0.0110)\end{array}$ & $\begin{array}{l}0.0120 * * * \\
(0.00373)\end{array}$ & $\begin{array}{l}-0.124^{\star *} \\
(0.0526)\end{array}$ & $\begin{array}{l}0.00412^{\star \star} \\
(0.00165)\end{array}$ & $\begin{array}{c}0.0510 * \star * \\
(0.0110)\end{array}$ & $\begin{array}{l}0.0117^{\star * *} \\
(0.00360)\end{array}$ & $\begin{array}{c}0.0213 \\
(0.0443)\end{array}$ & $\begin{array}{l}0.00136^{\star \star *} \\
(0.000471)\end{array}$ \\
\hline Year Dummy & Yes & Yes & Yes & Yes & Yes & Yes & Yes & Yes \\
\hline OCDE Dummy & Yes & Yes & Yes & Yes & Yes & Yes & Yes & Yes \\
\hline Size Dummy & Yes & Yes & Yes & Yes & Yes & Yes & Yes & Yes \\
\hline Sector Dummy & Yes & Yes & Yes & Yes & Yes & Yes & Yes & Yes \\
\hline Region Dummy & Yes & Yes & Yes & Yes & Yes & Yes & Yes & Yes \\
\hline Observations & 203.150 & 175.696 & 1.273 & 1.254 & 203.596 & 176.145 & 2.291 & 2.281 \\
\hline R-squared & 0.693 & 0.111 & 0.890 & 0.466 & 0.693 & 0.481 & 0.734 & 0.560 \\
\hline
\end{tabular}

Robust standard errors in parentheses

*** $p<0.01,{ }^{* *} p<0.05,{ }^{*} p<0.1$ 


\begin{tabular}{|c|c|c|c|c|c|c|c|c|c|c|c|c|}
\hline \multirow{3}{*}{$\begin{array}{l}\text { Treated Group } \\
\text { Control Group } \\
\text { Dependent Variable }\end{array}$} & \multicolumn{4}{|c|}{ Group 1} & \multicolumn{2}{|c|}{ Group 3} & \multicolumn{4}{|c|}{ Table A.5.d: Results of Difference-in-Differences (Robustness Check - unobservable time-variant characteristics) } & & \\
\hline & \multicolumn{2}{|c|}{ Group B } & \multicolumn{2}{|c|}{ Group C } & \multicolumn{2}{|c|}{ Group B } & \multicolumn{2}{|c|}{ Group C } & \multicolumn{2}{|c|}{ Group B } & \multicolumn{2}{|c|}{ Group C } \\
\hline & Labor & TFP & Labor & TFP & Labor & TFP & Labor & TFP & Labor & TFP & Labor & TFP \\
\hline Effect in 1998 & $\begin{array}{l}0.0943^{*} \\
(0.0565)\end{array}$ & $\begin{array}{c}0.0162 \\
(0.0451)\end{array}$ & $\begin{array}{c}0.180 \\
(0.156)\end{array}$ & $\begin{array}{c}0.0211 \\
(0.0649)\end{array}$ & $\begin{array}{c}0.129 \\
(0.0865)\end{array}$ & $\begin{array}{c}0.0173 \\
(0.0648)\end{array}$ & $\begin{array}{c}0.230 \\
(0.168)\end{array}$ & $\begin{array}{c}0.0197 \\
(0.0791)\end{array}$ & $\begin{array}{c}0.105 \\
(0.0647)\end{array}$ & $\begin{array}{c}0.0217 \\
(0.0497)\end{array}$ & $\begin{array}{c}0.189 \\
(0.158)\end{array}$ & $\begin{array}{c}0.0239 \\
(0.0684)\end{array}$ \\
\hline Effect in 1999 & $\begin{array}{c}0.109^{* *} \\
(0.0533)\end{array}$ & $\begin{array}{l}-0.0210 \\
(0.0431)\end{array}$ & $\begin{array}{l}0.0303 \\
(0.123)\end{array}$ & $\begin{array}{l}-0.0227 \\
(0.0609)\end{array}$ & $\begin{array}{c}0.133^{*} \\
(0.0802)\end{array}$ & $\begin{array}{l}-0.0159 \\
(0.0608)\end{array}$ & $\begin{array}{l}0.0578 \\
(0.137)\end{array}$ & $\begin{array}{l}-0.0279 \\
(0.0735)\end{array}$ & $\begin{array}{l}0.121^{\star *} \\
(0.0594)\end{array}$ & $\begin{array}{l}-0.0196 \\
(0.0456)\end{array}$ & $\begin{array}{l}0.0444 \\
(0.126)\end{array}$ & $\begin{array}{l}-0.0215 \\
(0.0626)\end{array}$ \\
\hline Effect in 2000 & $\begin{array}{l}0.130 * * \\
(0.0550)\end{array}$ & $\begin{array}{l}-0.0185 \\
(0.0442)\end{array}$ & $\begin{array}{l}0.0742 \\
(0.158)\end{array}$ & $\begin{array}{l}-0.0383 \\
(0.0613)\end{array}$ & $\begin{array}{c}0.106 \\
(0.0854)\end{array}$ & $\begin{array}{l}-0.0333 \\
(0.0621)\end{array}$ & $\begin{array}{l}0.0461 \\
(0.172)\end{array}$ & $\begin{array}{l}-0.0676 \\
(0.0746)\end{array}$ & $\begin{array}{l}0.146^{\star *} \\
(0.0595)\end{array}$ & $\begin{array}{l}-0.0266 \\
(0.0472)\end{array}$ & $\begin{array}{l}0.0845 \\
(0.160)\end{array}$ & $\begin{array}{c}-0.0457 \\
(0.0631)\end{array}$ \\
\hline Effect in 2001 & $\begin{array}{l}0.128^{\star *} \\
(0.0574)\end{array}$ & $\begin{array}{l}-0.0276 \\
(0.0415)\end{array}$ & $\begin{array}{c}0.281 \\
(0.199)\end{array}$ & $\begin{array}{l}0.00854 \\
(0.0587)\end{array}$ & $\begin{array}{c}0.0971 \\
(0.0891)\end{array}$ & $\begin{array}{l}-0.0568 \\
(0.0603)\end{array}$ & $\begin{array}{c}0.258 \\
(0.210)\end{array}$ & $\begin{array}{l}-0.0335 \\
(0.0730)\end{array}$ & $\begin{array}{c}0.127^{\star *} \\
(0.0614)\end{array}$ & $\begin{array}{l}-0.0375 \\
(0.0461)\end{array}$ & $\begin{array}{c}0.281 \\
(0.201)\end{array}$ & $\begin{array}{c}0.000887 \\
(0.0617)\end{array}$ \\
\hline Effect in 2002 & $\begin{array}{l}0.153^{\star \star \star} \\
(0.0550)\end{array}$ & $\begin{array}{c}0.0224 \\
(0.0442)\end{array}$ & $\begin{array}{c}0.182 \\
(0.130)\end{array}$ & $\begin{array}{c}0.0121 \\
(0.0624)\end{array}$ & $\begin{array}{c}0.135 \\
(0.0845)\end{array}$ & $\begin{array}{c}0.0168 \\
(0.0650)\end{array}$ & $\begin{array}{c}0.175 \\
(0.146)\end{array}$ & $\begin{array}{l}-0.00557 \\
(0.0774)\end{array}$ & $\begin{array}{l}0.141^{\star *} \\
(0.0612)\end{array}$ & $\begin{array}{l}0.00287 \\
(0.0492)\end{array}$ & $\begin{array}{c}0.167 \\
(0.132)\end{array}$ & $\begin{array}{l}-0.0108 \\
(0.0656)\end{array}$ \\
\hline Effect in 2003 & $\begin{array}{c}0.123^{\star \star} \\
(0.0511)\end{array}$ & $\begin{array}{l}-0.0284 \\
(0.0450)\end{array}$ & $\begin{array}{l}-0.0456 \\
(0.106)\end{array}$ & $\begin{array}{l}-0.0402 \\
(0.0606)\end{array}$ & $\begin{array}{c}0.141^{\star} \\
(0.0779)\end{array}$ & $\begin{array}{l}-0.0391 \\
(0.0630)\end{array}$ & $\begin{array}{l}-0.0240 \\
(0.122)\end{array}$ & $\begin{array}{l}-0.0647 \\
(0.0741)\end{array}$ & $\begin{array}{c}0.102^{\star} \\
(0.0590)\end{array}$ & $\begin{array}{l}-0.0347 \\
(0.0500)\end{array}$ & $\begin{array}{l}-0.0727 \\
(0.110)\end{array}$ & $\begin{array}{l}-0.0507 \\
(0.0641)\end{array}$ \\
\hline Effect in 2004 & $\begin{array}{l}0.113^{\star *} \\
(0.0561)\end{array}$ & $\begin{array}{l}-0.0184 \\
(0.0429)\end{array}$ & $\begin{array}{l}-0.0556 \\
(0.108)\end{array}$ & $\begin{array}{l}-0.0598 \\
(0.0620)\end{array}$ & $\begin{array}{c}0.132^{\star} \\
(0.0801)\end{array}$ & $\begin{array}{l}-0.0256 \\
(0.0611)\end{array}$ & $\begin{array}{l}-0.0231 \\
(0.122)\end{array}$ & $\begin{array}{l}-0.0854 \\
(0.0752)\end{array}$ & $\begin{array}{c}0.0968 \\
(0.0655)\end{array}$ & $\begin{array}{l}-0.00373 \\
(0.0475)\end{array}$ & $\begin{array}{l}-0.0746 \\
(0.112)\end{array}$ & $\begin{array}{l}-0.0529 \\
(0.0653)\end{array}$ \\
\hline Effect in 2005 & $\begin{array}{c}0.0875 \\
(0.0563)\end{array}$ & $\begin{array}{l}-0.0462 \\
(0.0417)\end{array}$ & $\begin{array}{l}-0.0822 \\
(0.108)\end{array}$ & $\begin{array}{l}-0.0574 \\
(0.0612)\end{array}$ & $\begin{array}{c}0.117 \\
(0.0796)\end{array}$ & $\begin{array}{l}-0.0547 \\
(0.0595)\end{array}$ & $\begin{array}{l}-0.0376 \\
(0.121)\end{array}$ & $\begin{array}{l}-0.0796 \\
(0.0735)\end{array}$ & $\begin{array}{c}0.0763 \\
(0.0658)\end{array}$ & $\begin{array}{l}-0.0321 \\
(0.0467)\end{array}$ & $\begin{array}{l}-0.101 \\
(0.113)\end{array}$ & $\begin{array}{l}-0.0494 \\
(0.0642)\end{array}$ \\
\hline Effect in 2006 & $\begin{array}{c}0.0600 \\
(0.0563)\end{array}$ & $\begin{array}{l}-0.0636 \\
(0.0439)\end{array}$ & $\begin{array}{l}-0.104 \\
(0.107)\end{array}$ & $\begin{array}{c}-0.115^{\star} \\
(0.0642)\end{array}$ & $\begin{array}{c}0.0608 \\
(0.0868)\end{array}$ & $\begin{array}{l}-0.0815 \\
(0.0629)\end{array}$ & $\begin{array}{l}-0.0978 \\
(0.125)\end{array}$ & $\begin{array}{c}-0.144^{\star} \\
(0.0783)\end{array}$ & $\begin{array}{c}0.0707 \\
(0.0649)\end{array}$ & $\begin{array}{l}-0.0534 \\
(0.0486)\end{array}$ & $\begin{array}{l}-0.102 \\
(0.111)\end{array}$ & $\begin{array}{l}-0.111^{*} \\
(0.0671)\end{array}$ \\
\hline Multiple Treatments & $\begin{array}{c}0.00657 \\
(0.00782)\end{array}$ & $\begin{array}{c}-0.0138^{\star} \\
(0.00712)\end{array}$ & $\begin{array}{c}0.0136 \\
(0.00915)\end{array}$ & $\begin{array}{l}-0.00822 \\
(0.00752)\end{array}$ & & & & & $\begin{array}{c}0.0144 \\
(0.0104)\end{array}$ & $\begin{array}{l}-0.00783 \\
(0.00890)\end{array}$ & $\begin{array}{c}0.0176 \\
(0.0112)\end{array}$ & $\begin{array}{c}-0.0124 \\
(0.00881)\end{array}$ \\
\hline Domestic Capital & $\begin{array}{l}-0.0147^{\star * \star} \\
(0.00568)\end{array}$ & & $\begin{array}{l}-0.144^{\star * \star} \\
(0.0394)\end{array}$ & & $\begin{array}{l}-0.0138^{\star \star} \\
(0.00570)\end{array}$ & & $\begin{array}{l}-0.119 * * \\
(0.0478)\end{array}$ & & $\begin{array}{l}-0.0148^{\star \star \star} \\
(0.00569)\end{array}$ & & $\begin{array}{l}-0.154^{\star \star *} \\
(0.0416)\end{array}$ & \\
\hline Imported Capital & $\begin{array}{c}0.0143 \\
(0.00900)\end{array}$ & & $\begin{array}{l}0.0770^{\star *} \\
(0.0319)\end{array}$ & & $\begin{array}{c}0.0142 \\
(0.00902)\end{array}$ & & $\begin{array}{l}0.0949 * * \\
(0.0415)\end{array}$ & & $\begin{array}{c}0.0144 \\
(0.00900)\end{array}$ & & $\begin{array}{l}0.0811^{* *} \\
(0.0359)\end{array}$ & \\
\hline Imported Input & $\begin{array}{c}0.383^{\star * *} \\
(0.136)\end{array}$ & $\begin{array}{l}0.445^{\star \star \star} \\
(0.0598)\end{array}$ & $\begin{array}{c}0.931^{\star * *} \\
(0.220)\end{array}$ & $\begin{array}{l}0.0131^{\star \star *} \\
(0.00505)\end{array}$ & $\begin{array}{c}0.381^{* * \star} \\
(0.136)\end{array}$ & $\begin{array}{l}0.445^{\star \star \star} \\
(0.0600)\end{array}$ & $\begin{array}{c}0.962^{\star \star \star} \\
(0.257)\end{array}$ & $\begin{array}{c}0.676^{\star \star \star} \\
(0.108)\end{array}$ & $\begin{array}{c}0.381^{* \star *} \\
(0.136)\end{array}$ & $\begin{array}{l}0.445^{\star \star \star} \\
(0.0598)\end{array}$ & $\begin{array}{c}0.890^{\star \star \star} \\
(0.238)\end{array}$ & $\begin{array}{c}0.659^{\star \star *} \\
(0.104)\end{array}$ \\
\hline Export Coefficient & $\begin{array}{l}0.106^{\star \star *} \\
(0.0363)\end{array}$ & $\begin{array}{c}-0.115^{\star \star *} \\
(0.0130)\end{array}$ & $\begin{array}{l}-0.00709 \\
(0.0788)\end{array}$ & $\begin{array}{c}-0.00361^{* *} \\
(0.00153)\end{array}$ & $\begin{array}{l}0.110^{\star \star *} \\
(0.0367)\end{array}$ & $\begin{array}{l}-0.111^{* * *} \\
(0.0131)\end{array}$ & $\begin{array}{c}0.107 \\
(0.0940)\end{array}$ & $\begin{array}{l}-0.240^{* * *} \\
(0.0622)\end{array}$ & $\begin{array}{l}0.109^{\star \star \star} \\
(0.0365)\end{array}$ & $\begin{array}{l}-0.114^{\star * *} \\
(0.0130)\end{array}$ & $\begin{array}{c}0.0494 \\
(0.0894)\end{array}$ & $\begin{array}{l}-0.323^{\star * *} \\
(0.0572)\end{array}$ \\
\hline
\end{tabular}




\begin{tabular}{|c|c|c|c|c|c|c|c|c|c|c|c|c|}
\hline \multirow{2}{*}{ Import Coefficient } & & & & & & & & & & & & \\
\hline & $\begin{array}{c}-1.238^{\star 2 \pi} \\
(0.182)\end{array}$ & $\begin{array}{c}-0.582^{\star \star \star} \\
(0.0704)\end{array}$ & $\begin{array}{c}-1.568^{\star \star \star} \\
(0.510)\end{array}$ & $\begin{array}{l}-0.0129^{\star \star} \\
(0.00608)\end{array}$ & $\begin{array}{c}-1.239 * * * \\
(0.182)\end{array}$ & $\begin{array}{c}-0.578^{\star \star *} \\
(0.0706)\end{array}$ & $\begin{array}{c}-1.661^{\star \star *} \\
(0.633)\end{array}$ & $\begin{array}{c}-0.802^{\star \star *} \\
(0.160)\end{array}$ & $\begin{array}{c}-1.237^{\star \star \star} \\
(0.181)\end{array}$ & $\begin{array}{c}-0.579^{\star \star *} \\
(0.0705)\end{array}$ & $\begin{array}{c}-1.514^{\star \star \star} \\
(0.580)\end{array}$ & $\begin{array}{c}-0.826^{\star \star \star} \\
(0.155)\end{array}$ \\
\hline Net Sales Revenue & $\begin{array}{c}0.554^{\star \star *} \\
(0.00726)\end{array}$ & $\begin{array}{c}0.100^{\star \star *} \\
(0.00238)\end{array}$ & $\begin{array}{l}0.543^{\star \star *} \\
(0.0267)\end{array}$ & $\begin{array}{l}-0.00292^{\star * *} \\
(0.000434)\end{array}$ & $\begin{array}{c}0.552^{\star \star *} \\
(0.00731)\end{array}$ & $\begin{array}{c}0.100^{\star \star *} \\
(0.00239)\end{array}$ & $\begin{array}{l}0.525^{\star \star \star} \\
(0.0296)\end{array}$ & $\begin{array}{l}0.110^{\star \star *} \\
(0.0125)\end{array}$ & $\begin{array}{c}0.554^{* \star *} \\
(0.00727)\end{array}$ & $\begin{array}{c}0.101^{\star \star *} \\
(0.00239)\end{array}$ & $\begin{array}{l}0.542^{\star \star \star} \\
(0.0279)\end{array}$ & $\begin{array}{l}0.117^{* * *} \\
(0.0120)\end{array}$ \\
\hline $\begin{array}{l}\text { Number of } \\
\text { Employees }\end{array}$ & $\begin{array}{l}-0.349 * * \star \\
(0.0260)\end{array}$ & & $\begin{array}{l}-0.488^{\star * \star} \\
(0.0319)\end{array}$ & & $\begin{array}{l}-0.336^{\star \star \star} \\
(0.0289)\end{array}$ & & $\begin{array}{l}-0.504^{\star \star *} \\
(0.0414)\end{array}$ & & $\begin{array}{l}-0.334^{\star * *} \\
(0.0283)\end{array}$ & & $\begin{array}{l}-0.471^{\star \star \star} \\
(0.0399)\end{array}$ & \\
\hline Cost / Revenue & $\begin{array}{l}-2.250^{* * *} \\
(0.0764)\end{array}$ & $\begin{array}{l}-1.273^{\star \star *} \\
(0.0276)\end{array}$ & $\begin{array}{c}-2.217^{\star \star \star} \\
(0.268)\end{array}$ & $\begin{array}{c}-0.00763^{\star \star} \\
(0.00327)\end{array}$ & $\begin{array}{l}-2.253^{\star \star *} \\
(0.0767)\end{array}$ & $\begin{array}{l}-1.275^{\star \star \star} \\
(0.0278)\end{array}$ & $\begin{array}{c}-2.310^{\star \star \star} \\
(0.307)\end{array}$ & $\begin{array}{c}-1.000^{\star * *} \\
(0.114)\end{array}$ & $\begin{array}{c}-2.252^{\star \star \star} \\
(0.0766)\end{array}$ & $\begin{array}{l}-1.274^{\star \star \star} \\
(0.0277)\end{array}$ & $\begin{array}{c}-2.347^{\star \star \star} \\
(0.291)\end{array}$ & $\begin{array}{c}-0.978^{\star \star \star} \\
(0.114)\end{array}$ \\
\hline Firms' Age & $\begin{array}{l}0.0312^{\star * *} \\
(0.00786)\end{array}$ & $\begin{array}{l}-0.0535^{\star \star \star} \\
(0.00360)\end{array}$ & $\begin{array}{l}-0.0496 \\
(0.0464)\end{array}$ & $\begin{array}{l}-0.000176 \\
(0.000496)\end{array}$ & $\begin{array}{l}0.0311^{\star * *} \\
(0.00791)\end{array}$ & $\begin{array}{l}-0.0538^{\star \star \star} \\
(0.00362)\end{array}$ & $\begin{array}{l}-0.0629 \\
(0.0588)\end{array}$ & $\begin{array}{c}0.0335 \\
(0.0247)\end{array}$ & $\begin{array}{l}0.0310^{\star * *} \\
(0.00787)\end{array}$ & $\begin{array}{l}-0.0529 * \star \star \\
(0.00360)\end{array}$ & $\begin{array}{l}-0.0560 \\
(0.0497)\end{array}$ & $\begin{array}{l}0.0369^{*} \\
(0.0215)\end{array}$ \\
\hline Years of Schooling & $\begin{array}{c}-0.0122 \\
(0.0144)\end{array}$ & $\begin{array}{l}-0.309^{* * \star} \\
(0.00708)\end{array}$ & $\begin{array}{c}0.0764 \\
(0.0701)\end{array}$ & $\begin{array}{c}0.00618^{* * *} \\
(0.00152)\end{array}$ & $\begin{array}{l}-0.0144 \\
(0.0145)\end{array}$ & $\begin{array}{l}-0.310^{\star \star *} \\
(0.00710)\end{array}$ & $\begin{array}{c}0.0600 \\
(0.0852)\end{array}$ & $\begin{array}{l}-0.306^{\star \star \star} \\
(0.0471)\end{array}$ & $\begin{array}{l}-0.0127 \\
(0.0145)\end{array}$ & $\begin{array}{l}-0.308^{\star \star \star} \\
(0.00709)\end{array}$ & $\begin{array}{c}0.0667 \\
(0.0856)\end{array}$ & $\begin{array}{l}-0.254^{\star \star \star} \\
(0.0494)\end{array}$ \\
\hline Skilled Labor & $\begin{array}{l}0.127^{\star \star \star} \\
(0.0469)\end{array}$ & $\begin{array}{l}0.549^{\star * *} \\
(0.0282)\end{array}$ & $\begin{array}{l}0.0693 \\
(0.180)\end{array}$ & $\begin{array}{l}-0.0234^{\star \star \star} \\
(0.00487)\end{array}$ & $\begin{array}{l}0.135^{\star \star \star} \\
(0.0475)\end{array}$ & $\begin{array}{l}0.552^{\star \star *} \\
(0.0286)\end{array}$ & $\begin{array}{l}0.0299 \\
(0.269)\end{array}$ & $\begin{array}{c}0.263^{*} \\
(0.156)\end{array}$ & $\begin{array}{l}0.130^{\star \star *} \\
(0.0474)\end{array}$ & $\begin{array}{l}0.548^{\star \star *} \\
(0.0285)\end{array}$ & $\begin{array}{l}0.0946 \\
(0.227)\end{array}$ & $\begin{array}{l}0.317^{\star *} \\
(0.138)\end{array}$ \\
\hline Average Salary & $\begin{array}{c}0.520^{\star \star \star} \\
(0.00956)\end{array}$ & $\begin{array}{c}0.211^{\star \star \star} \\
(0.00420)\end{array}$ & $\begin{array}{l}0.426^{\star \star \star} \\
(0.0418)\end{array}$ & $\begin{array}{l}0.00273^{\star * \star} \\
(0.000950)\end{array}$ & $\begin{array}{c}0.521^{\star \star \star} \\
(0.00963)\end{array}$ & $\begin{array}{l}0.211^{\star \star \star} \\
(0.00422)\end{array}$ & $\begin{array}{l}0.425^{\star \star \star} \\
(0.0542)\end{array}$ & $\begin{array}{l}0.161^{\star \star *} \\
(0.0242)\end{array}$ & $\begin{array}{c}0.519 * \star \star \\
(0.00957)\end{array}$ & $\begin{array}{c}0.210^{\star \star \star} \\
(0.00420)\end{array}$ & $\begin{array}{l}0.402^{\star \star \star} \\
(0.0443)\end{array}$ & $\begin{array}{l}0.156^{\star \star \star} \\
(0.0212)\end{array}$ \\
\hline Investment & $\begin{array}{l}0.0112^{\star * \star} \\
(0.000611)\end{array}$ & $\begin{array}{l}-0.00203^{\star * *} \\
(0.000295)\end{array}$ & $\begin{array}{c}0.00338 \\
(0.00353)\end{array}$ & $\begin{array}{c}-0.000255^{\star \star \star} \\
(6.40 \mathrm{e}-05)\end{array}$ & $\begin{array}{l}0.0113^{\star * *} \\
(0.000613)\end{array}$ & $\begin{array}{l}-0.00201^{\star \star *} \\
(0.000296)\end{array}$ & $\begin{array}{c}0.00431 \\
(0.00393)\end{array}$ & $\begin{array}{c}-0.000642 \\
(0.00188)\end{array}$ & $\begin{array}{c}0.0112^{\star \star \star} \\
(0.000612)\end{array}$ & $\begin{array}{l}-0.00202^{\star * \star} \\
(0.000295)\end{array}$ & $\begin{array}{r}0.00319 \\
(0.00376)\end{array}$ & $\begin{array}{r}-0.00116 \\
(0.00176)\end{array}$ \\
\hline Solvency & $\begin{array}{l}1.323^{\star \star \star} \\
(0.0976)\end{array}$ & $\begin{array}{l}0.607^{\star \star *} \\
(0.0379)\end{array}$ & $\begin{array}{c}1.795^{\star \star *} \\
(0.298)\end{array}$ & $\begin{array}{l}-0.00388 \\
(0.00389)\end{array}$ & $\begin{array}{l}1.325^{\star \star \star} \\
(0.0980)\end{array}$ & $\begin{array}{l}0.609 * \star \star \\
(0.0380)\end{array}$ & $\begin{array}{c}1.917^{* \star *} \\
(0.354)\end{array}$ & $\begin{array}{c}0.543^{\star \star *} \\
(0.192)\end{array}$ & $\begin{array}{l}1.323^{\star \star \star} \\
(0.0980)\end{array}$ & $\begin{array}{l}0.605^{\star \star \star} \\
(0.0380)\end{array}$ & $\begin{array}{c}1.819 * * * \\
(0.351)\end{array}$ & $\begin{array}{l}0.379 * * \\
(0.187)\end{array}$ \\
\hline Revenue Growth & $\begin{array}{l}-0.444^{\star \star \star} \\
(0.0241)\end{array}$ & $\begin{array}{l}0.0304^{\star \star *} \\
(0.00615)\end{array}$ & $\begin{array}{c}-0.388^{\star \star \star} \\
(0.119)\end{array}$ & $\begin{array}{c}0.00410^{\star * *} \\
(0.00106)\end{array}$ & $\begin{array}{l}-0.444^{\star * \star} \\
(0.0241)\end{array}$ & $\begin{array}{l}0.0301^{\star * \star} \\
(0.00617)\end{array}$ & $\begin{array}{c}-0.394^{* * *} \\
(0.130)\end{array}$ & $\begin{array}{c}0.0545 \\
(0.0332)\end{array}$ & $\begin{array}{l}-0.445^{\star \star \star} \\
(0.0241)\end{array}$ & $\begin{array}{l}0.0306^{\star \star \star} \\
(0.00616)\end{array}$ & $\begin{array}{c}-0.412^{\star \star \star} \\
(0.126)\end{array}$ & $\begin{array}{l}0.0791^{\star *} \\
(0.0310)\end{array}$ \\
\hline Employment Growth & $\begin{array}{l}0.451^{\star \star *} \\
(0.0234)\end{array}$ & $\begin{array}{c}0.00961 \\
(0.00693)\end{array}$ & $\begin{array}{l}0.286^{\star \star} \\
(0.131)\end{array}$ & $\begin{array}{l}-0.00218 \\
(0.00147)\end{array}$ & $\begin{array}{l}0.452^{\star \star \star} \\
(0.0236)\end{array}$ & $\begin{array}{c}0.00881 \\
(0.00699)\end{array}$ & $\begin{array}{c}0.257 \\
(0.169)\end{array}$ & $\begin{array}{l}-0.0884^{\star} \\
(0.0509)\end{array}$ & $\begin{array}{l}0.450^{\star \star \star} \\
(0.0235)\end{array}$ & $\begin{array}{c}0.00879 \\
(0.00697)\end{array}$ & $\begin{array}{l}0.246^{\star} \\
(0.145)\end{array}$ & $\begin{array}{l}-0.0737^{*} \\
(0.0438)\end{array}$ \\
\hline Productivity Growth & $\begin{array}{l}0.475^{\star \star *} \\
(0.0206)\end{array}$ & $\begin{array}{l}0.0325^{\star * *} \\
(0.00180)\end{array}$ & $\begin{array}{c}0.469 * * * \\
(0.116)\end{array}$ & $\begin{array}{c}0.000164 \\
(0.000102)\end{array}$ & $\begin{array}{l}0.475^{\star \star \star} \\
(0.0207)\end{array}$ & $\begin{array}{l}0.0324^{\star * *} \\
(0.00180)\end{array}$ & $\begin{array}{l}0.471^{\star * \star} \\
(0.120)\end{array}$ & $\begin{array}{c}0.0139 * * \\
(0.00695)\end{array}$ & $\begin{array}{l}0.475^{\star \star \star} \\
(0.0207)\end{array}$ & $\begin{array}{l}0.0325^{\star \star *} \\
(0.00180)\end{array}$ & $\begin{array}{c}0.470^{\star \star \star} \\
(0.118)\end{array}$ & $\begin{array}{l}0.0164^{* *} \\
(0.00711)\end{array}$ \\
\hline Profitable & $\begin{array}{l}0.0907^{\star \star \star} \\
(0.00697)\end{array}$ & $\begin{array}{l}0.0405^{\star * \star} \\
(0.00339)\end{array}$ & $\begin{array}{c}0.0960^{\star \star \star} \\
(0.0292)\end{array}$ & $\begin{array}{c}4.41 \mathrm{e}-05 \\
(0.000618)\end{array}$ & $\begin{array}{l}0.0918^{\star \star \star} \\
(0.00702)\end{array}$ & $\begin{array}{l}0.0411^{\star \star \star} \\
(0.00341)\end{array}$ & $\begin{array}{l}0.129^{\star \star \star} \\
(0.0362)\end{array}$ & $\begin{array}{l}0.0408^{\star *} \\
(0.0184)\end{array}$ & $\begin{array}{l}0.0909^{\star \star *} \\
(0.00699)\end{array}$ & $\begin{array}{l}0.0404^{\star * \star} \\
(0.00340)\end{array}$ & $\begin{array}{l}0.103^{\star \star \star} \\
(0.0318)\end{array}$ & $\begin{array}{c}0.0216 \\
(0.0167)\end{array}$ \\
\hline Multinational Status & $\begin{array}{c}0.0414^{\star \star \star} \\
(0.0114)\end{array}$ & $\begin{array}{c}-0.0648^{\star \star \star} \\
(0.00627)\end{array}$ & $\begin{array}{c}-0.0859^{* *} \\
(0.0378)\end{array}$ & $\begin{array}{c}0.000791 \\
(0.000580)\end{array}$ & $\begin{array}{c}0.0428^{\star \star *} \\
(0.0116)\end{array}$ & $\begin{array}{l}-0.0651^{\star \star *} \\
(0.00638)\end{array}$ & $\begin{array}{c}-0.109^{*} \\
(0.0632)\end{array}$ & $\begin{array}{l}-0.141^{\star \star \star} \\
(0.0387)\end{array}$ & $\begin{array}{c}0.0429^{\star * *} \\
(0.0114)\end{array}$ & $\begin{array}{l}-0.0659^{\star \star \star} \\
(0.00632)\end{array}$ & $\begin{array}{l}-0.0614 \\
(0.0481)\end{array}$ & $\begin{array}{c}-0.167^{* * \star} \\
(0.0310)\end{array}$ \\
\hline
\end{tabular}




\begin{tabular}{|c|c|c|c|c|c|c|c|c|c|c|c|c|}
\hline & & & & & & & & & & & & \\
\hline Year Dummy & Yes & Yes & Yes & Yes & Yes & Yes & Yes & Yes & Yes & Yes & Yes & Yes \\
\hline OCDE Dummy & Yes & Yes & Yes & Yes & Yes & Yes & Yes & Yes & Yes & Yes & Yes & Yes \\
\hline Size Dummy & Yes & Yes & Yes & Yes & Yes & Yes & Yes & Yes & Yes & Yes & Yes & Yes \\
\hline Sector Dummy & Yes & Yes & Yes & Yes & Yes & Yes & Yes & Yes & Yes & Yes & Yes & Yes \\
\hline Region Dummy & Yes & Yes & Yes & Yes & Yes & Yes & Yes & Yes & Yes & Yes & Yes & Yes \\
\hline Observations & 78,137 & 76,878 & 2.698 & 2,674 & 77,479 & 76,220 & 2,040 & 2,016 & 77,847 & 76,592 & 2.408 & 2,388 \\
\hline R-squared & 0.707 & 0.445 & 0.694 & 0.446 & 0.705 & 0.445 & 0.653 & 0.457 & 0.705 & 0.445 & 0.664 & 0.439 \\
\hline
\end{tabular}

Robust standard errors in parentheses

*** $p<0.01,{ }^{* *} p<0.05,{ }^{*} p<0.1$ 


\section{Appendix VI: Measuring TFP}

Our TFP measure is calculated following Levinsohn and Petrin (2003) as the firm-level Solow residual based on a Cobb-Douglas production function with labor, capital and intermediates as inputs. Implementation of this approach requires the following variables:

a) Labor - Measured as human capital, calculated as total number of firm employees times employee's average number of years of schooling. Results using the total number of employees are also available upon request.

b) Capital - As there is no measure of firm capital stock in our main database (PIA), we proceeded as follows. First, we used the perpetual inventory method to construct the capital stock at sector level using investments made from 1985 to 1995 . Then we imputed the sectoral capital stock to firms according to their market shares in 1995. For example, if the capital stock of sector $\mathrm{j}$ in 1995 were 100 and firm i's market share were $15 \%$, then the capital stock imputed to firm i would be 15 . Given this initial capital stock in 1995, from then onwards the yearly time series of each firm's capital stock was generated using its investments and depreciation.

c) Input - The PIA dataset reports firm input expenditure.

d) Output - We use the total value of production as our measure of production.

To deal with possible biases arising from the fact that the firm likely makes profitmaximizing decisions based on shocks that are unobservable to the econometrician, implementation of the Levinsohn and Petrin (2003) procedure also requires:

e) Energy - The PIA dataset reports firm energy expenditure.

The estimated Cobb-Douglas coefficients when they are assumed to be the same across sectors and when they are allowed to differ across sectors are reported in Tables A.6.a 
and A.6.b. respectively. These results are in line with existing estimates obtained, for instance, by Lopez-Cordova and Moreira (2003) from the same dataset (PIA) in the period 1996-2000, through the alternative Olley and Pakes (1996) approach.

\begin{tabular}{lc}
\hline \multicolumn{2}{c}{ Table A.6.a: TFP Results for Full Sample } \\
\hline \multicolumn{2}{l}{ Dependent Variable: } \\
Total Value of Production \\
\hline Human Capital & 0.30 \\
& $(0.006)^{\star \star \star}$ \\
Input Consumption & 0.43 \\
& $(0.005)^{\star \star \star}$ \\
Capital Stock & 0.34 \\
& $(0.035)^{\star \star \star}$ \\
\hline Wald Test for Constant Returns & 4.54 \\
P-value & $3.3 \%$ \\
\hline * significant at $10 \%,{ }^{* *}$ at $5 \%$ and $* * *$ at $1 \%$ \\
\end{tabular}




\begin{tabular}{|c|c|c|c|}
\hline \multicolumn{4}{|c|}{ Table A.6.b: TFP Results per Sector } \\
\hline & Labor & Materials & Capital \\
\hline \multirow[t]{2}{*}{ Food and Beverages } & 0.42 & 0.50 & 0.10 \\
\hline & $(0.0082)^{\star \star \star}$ & $(0.0145)^{* * *}$ & $(0.0056)^{* * *}$ \\
\hline \multirow[t]{2}{*}{ Tobacco } & 0.41 & 0.30 & 0.10 \\
\hline & $(0.036)^{* * *}$ & $(0.0632)^{* * *}$ & $(0.0249)^{* * *}$ \\
\hline \multirow[t]{2}{*}{ Textiles } & 0.17 & 0.54 & 0.15 \\
\hline & $(0.0096)^{* * *}$ & $(0.0204)^{* * *}$ & $(0.0103)^{* * *}$ \\
\hline \multirow[t]{2}{*}{ Apparel } & 0.30 & 0.46 & 0.10 \\
\hline & $(0.0038)^{* * *}$ & $(0.0099)^{* * *}$ & $(0.0044)^{* * *}$ \\
\hline \multirow[t]{2}{*}{ Leather } & 0.28 & 0.37 & 0.13 \\
\hline & $(0.0047)^{* * *}$ & $(0.0136)^{* * *}$ & $(0.0057)^{* * *}$ \\
\hline \multirow[t]{2}{*}{ Wood } & 0.17 & 0.62 & 0.11 \\
\hline & $(0.0073)^{* * *}$ & $(0.0285)^{* * *}$ & $(0.0062)^{* * *}$ \\
\hline \multirow[t]{2}{*}{ Paper } & 0.26 & 0.65 & 0.16 \\
\hline & $(0.0199)^{* * *}$ & $(0.0265)^{* * *}$ & $(0.012)^{* * *}$ \\
\hline \multirow[t]{2}{*}{ Printing } & 0.18 & 0.96 & 0.23 \\
\hline & $(0.0125)^{* * *}$ & $(0.0301)^{* * *}$ & $(0.0115)^{* * *}$ \\
\hline \multicolumn{4}{|l|}{ Coke \& Refined } \\
\hline \multirow[t]{2}{*}{ Petroleum } & 0.47 & 0.92 & 0.18 \\
\hline & $(0.0398)^{* * *}$ & $(0.108)^{* * *}$ & $(0.0232)^{* * *}$ \\
\hline \multirow[t]{2}{*}{ Chemicals } & 0.33 & 0.66 & 0.11 \\
\hline & $(0.0128)^{* * *}$ & $(0.0231)^{* * *}$ & $(0.0075)^{* * *}$ \\
\hline \multirow[t]{2}{*}{ Plastic \& Rubber } & 0.19 & 0.79 & 0.12 \\
\hline & $(0.01)^{* * *}$ & $(0.018)^{* * *}$ & $(0.0063)^{* * *}$ \\
\hline \multirow[t]{2}{*}{ Non-Metalic Minerals } & 0.17 & 0.62 & 0.16 \\
\hline & $(0.005)^{* * *}$ & $(0.0141)^{* * *}$ & $(0.0089)^{* * *}$ \\
\hline \multirow[t]{2}{*}{ Basic Metals } & 0.34 & 0.33 & 0.18 \\
\hline & $(0.0214)^{* * *}$ & $(0.0293)^{* * *}$ & $(0.0157)^{* * *}$ \\
\hline \multirow[t]{2}{*}{ Metal Products } & 0.24 & 0.78 & 0.19 \\
\hline & $(0.0077)^{* * *}$ & $(0.0249)^{* * *}$ & $(0.0087)^{* * *}$ \\
\hline \multicolumn{4}{|l|}{ Machinery \& } \\
\hline \multirow{2}{*}{ Equipment } & 0.23 & 0.70 & 0.20 \\
\hline & $(0.0105)^{* * *}$ & $(0.0198)^{* * *}$ & $(0.0081)^{* * *}$ \\
\hline \multirow[t]{2}{*}{ Office Equipment } & 0.27 & 0.75 & 0.18 \\
\hline & $(0.0723)^{* * *}$ & $(0.1929)^{* *}$ & $(0.0377)^{* * *}$ \\
\hline \multirow[t]{2}{*}{ Electrical Equipment } & 0.28 & 0.43 & 0.26 \\
\hline & $(0.0241)^{* * *}$ & $(0.0333)^{* * *}$ & $(0.0156)^{* * *}$ \\
\hline \multirow[t]{2}{*}{ Eletronics } & 0.27 & 0.62 & 0.16 \\
\hline & $(0.0205)^{* * *}$ & $(0.038)^{* * *}$ & $(0.0214)^{* * *}$ \\
\hline Health Equipments & 0.28 & 0.46 & 0.24 \\
\hline & $(0.021)^{* * *}$ & $(0.0695)^{* * *}$ & $(0.0239)^{* * *}$ \\
\hline Moto Vehicles & 0.15 & 0.59 & 0.19 \\
\hline & $(0.0118)^{* * *}$ & $(0.0243)^{* * *}$ & $(0.0127)^{* * *}$ \\
\hline Other Transport & & & \\
\hline Equipment & 0.23 & 0.24 & 0.38 \\
\hline & $(0.0217)^{* * *}$ & $(0.0764)^{* *}$ & $(0.0347)^{* * *}$ \\
\hline Furniture and Other & & & \\
\hline Equipment & 0.27 & 0.64 & 0.19 \\
\hline & $(0.0113)^{* * *}$ & $(0.0211)^{* * *}$ & $(0.0088)^{* * *}$ \\
\hline
\end{tabular}


